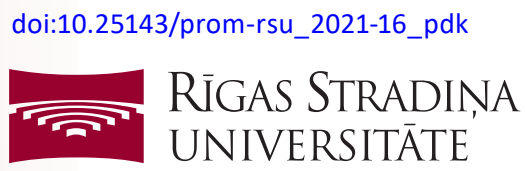

\title{
Ludmila Voložonoka
}

\section{Sievietes reproduktīvās mazspējas iemesli un genomiskās pieejas to risināšanai}

Promocijas darba kopsavilkums zinātniskā doktora grāda "zinātnes doktors (Ph.D.)" iegūšanai Nozare - medicīnas bāzes zinātnes, tai skaitā farmācija Apakšnozare - medicīniskā ǵenētika 


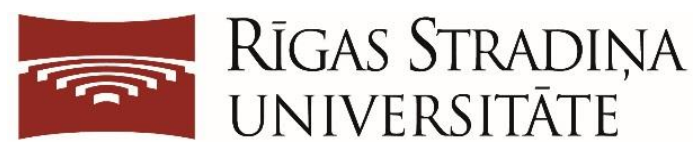

\author{
Ludmila Voložonoka \\ ORCID 0000-0003-0413-1481
}

\title{
Sievietes reproduktīvās mazspējas iemesli un genomiskās pieejas to risināšanai
}

Promocijas darba kopsavilkums zinātniskā doktora grāda "zinātnes doktors (Ph.D.)" iegūšanai

Nozare - medicīnas bāzes zinātnes, tai skaitā farmācija Apakšnozare - medicīniskā g̊enētika

Rīga, 2021 
Promocijas darbs izstrādāts Rīgas Stradiṇa universitātē, Molekulārās ǵenētikas zinātniskajā laboratorijā, kā arī klīnikā "IVF Riga", Latvijā

Promocijas darba vadītājas:

Dr. med. docente Anna Miskova,

Rīgas Stradiņa universitāte, Latvija

Dr. med. Inga Kempa,

Rīgas Stradiṇa universitāte, Latvija

Zinātniskā konsultante:

Dr. med. Linda Gailīte,

Rīgas Stradiṇa universitāte, Latvija

Oficiālais recenzents:

Dr. biol. profesors Edvīns Miklaševičs,

Rīgas Stradiṇa universitāte, Latvija

Ph.D. Kristina Rull,

Tartu Universitāte, Igaunija

Profesors Andres Saluments,

Tartu Universitāte, Igaunija

Promocijas darbs tiks aizstāvēts medicīnas bāzes zinātnes, tai skaitā farmācijas promocijas padomes atklātā sēdē 2021. gada 3. novembrī plkst. 12.00 tiešsaites platformā Zoom.

Ar promocijas darbu var iepazīties RSU bibliotēkā un RSU tīmekḷa vietnē: https://www.rsu.lv/promocijas-darbi

Promocijas padomes sekretāre:

Dr. med. asociētā profesore Zanda Daneberga 


\section{Saturs}

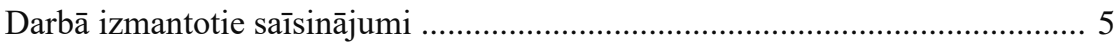

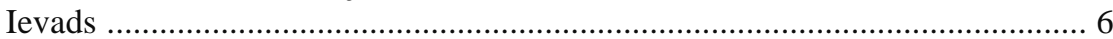

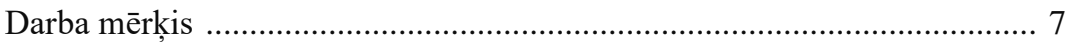

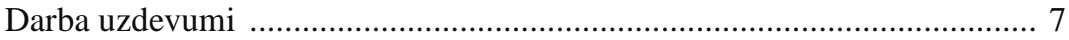

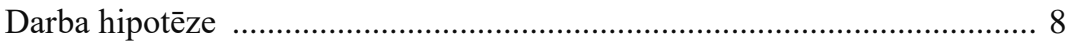

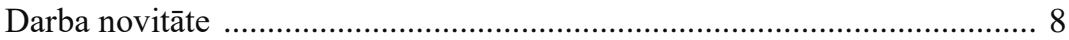

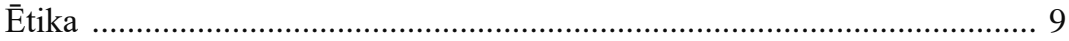

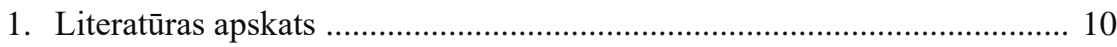

1.1. Sievietes reproduktīvās mazspējas ǵenētiskie iemesli ...................... 10

1.2. Ģenētiskā testēšana diagnostikas ietvaros ....................................... 15

1.2.1. Pirmsimplantācijas embriju ġenētiskā testēšana .................... 16

1.2.2. Pārtraukušās grūtniecības ǵenētiskā testēšana ....................... 16

1.3. Literatūras apskats: kopsavilkums ................................................ 17

2. Divu pilna genoma amplifikācijas tehniku veiktspējas salīdzinājums pirmsimplantācijas embriju ǵenētiskajā testēšanā .................................. 18

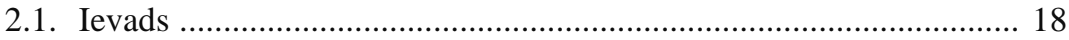

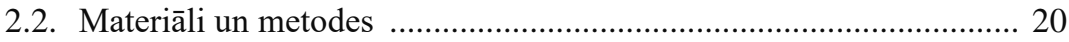

2.2.1. Pirmsklīniska sagatavošanās PG̣T ciklam ............................ 20

2.2.2. Klīnisko gadījumu analīze ................................................... 20

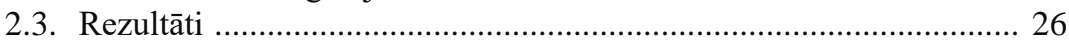

2.3.1. Divu pilnu genomu amplifikācijas metožu salīdzinājums ..... 26

3. Mātes šūnu kontaminācijas izraisītas nepareizas diagnozes mazināšana agrīnas grūtniecības zaudēšanas ǵenētiskajā testēšanā ............................. 30

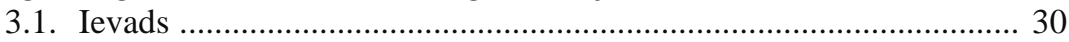

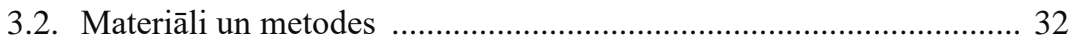

3.2.1. Pacienti un pārtraukušās grūtniecības materiāla hromosomu anlīze ............................................................ 32

3.2.2. Mātes šūnu kontaminācijas ǵenētiskās testēšanas protokola izstrāde ................................................................ 32

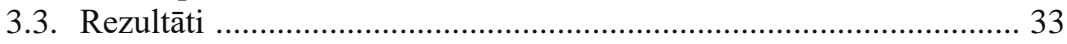

3.3.1. Vizuāla pārtraukušās grūtniecības materiāla novērtěšana un mātes šūnu kontaminācijas ǵenētiskā testēšana ................ 33

3.3.2. Hromosomu analīze ar salīdzinošo genoma hibridizāciju

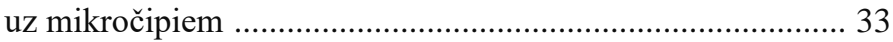

3.3.3. Augsta mātes šūnu kontaminācijas riska pārtraukušās grūtniecības materiāla analīze

4. Dzemdes kakla nepietiekamības izraisītu priekšlaicīgu dzemdību ǵenētiskā etiologija: sistemātiska gēnu analīze un pacientu nākamās paaudzes sekvencēšanas datu interpretācija 


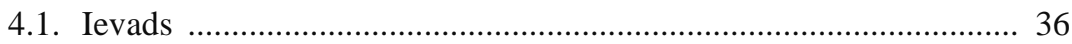

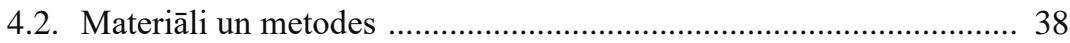

4.2.1. Dzemdes kakla biologijāa iesaistīto gēnu identificēšana ........ 38

4.2.2. Nākamās paaudzes sekvencēšana pacientiem ar dzemdes

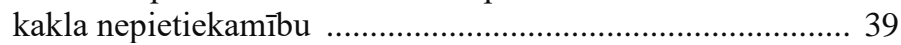

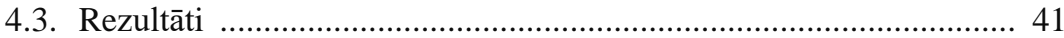

4.3.1. Gēnu analīze: gēni, kas saistīti ar dzemdes kakla nepietiekamību, galvenokārt ir sindromiski ........................ 41

4.3.2. Pacientu nākamās paaudzes sekvencēšanas datu analīze ...... 42

4.3.3. Molekulāro gēnu ceḷu bagātināšanas analīze ......................... 43

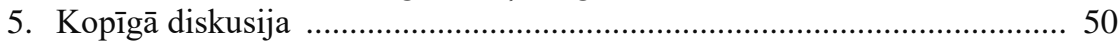

5.1. Labākās tehnolog̣ijas izvēle pirmsimplantācijas ǵenētiskajai

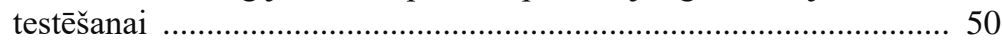

5.2. Pārtraukušās grūtniecības materiāla ğenētiskās testēšanas uzticamības uzlabošana ............................................................... 51

5.3. Dzemdes kakla nepietiekamības ǵenētiskās etiologijas

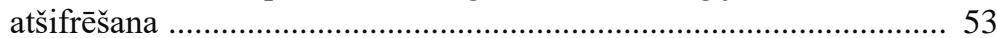

5.4. Ieteikumi sieviešu reproduktīvās mazspējas ǵenētiskajai novērtēšanai pētījumos un klīnikā ................................................ 56

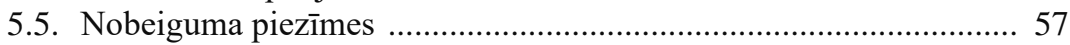

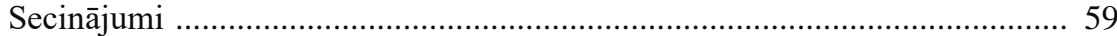

Publikācijas un ziņojumi par promocijas darba tēmu ...................................... 60

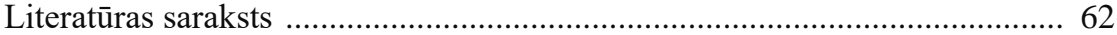

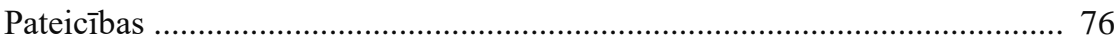

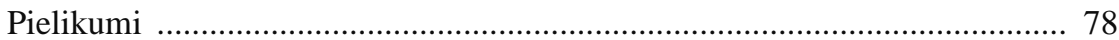




\section{Darbā izmantotie sā̄sinājumi}

ACMG Amerikas medicīniskās genētikas koledža (angl. American college of Medical Genetics)

DNS Dezoksiribonuklē̄nskābe

EDS Elersa-Danlo sindroms

FSH Folikulu stimulējošais hormons

GnRH Gonadotropīnu atbrīvojošais hormons

HGNC HUGO gēnu nomenklatūra

LH Luteinizējošais hormons

MDA Phi-29 polimerāzes pilna genoma amplifikācijas metode (angl. multiple displacement amplification)

nt Nukleotīds

OMIM Interneta katalogs Mendel̦a iedzimšanai cilvēkā (angl. Online Mendelian inheritance in man)

PĶR Polimerāzes ķēdes reakcija

PG̣T Pirmsimplantācijas ǵenētiskā testēšana

PG̣T-A Pirmsimplantācijas ǵenētiskā testēšana aneiploīdijām

PG̣T-M Pirmsimplantācijas ǵenētiskā testēšana monogēnajām saslimšanām

PVO Pasaules Veselības organizācija

VCF Fails ar sasauktiem gēnu variantiem (angl. variant called file)

VUS Neskaidras nozīmes variants

(angl. variant of unknown significance) 


\section{Ievads}

Sievietes reproduktīvā mazspēja ir globāla problēma, kurai ir nozīmīgas medicīniskas, sociālas un finansiālas sekas, dažās valstīs tā skar 16,2\% sieviešu (Inhorn \& Patrizio, 2014; Maddirevula et al., 2020; Singh, 2004). Pastāv vairākas reproduktīvās mazspējas, tajā skaitā neauglības, definīcijas, piemēram, PVO neauglību definē kā "reproduktīvās sistēmas slimību, ko raksturo klīniskas grūtniecības neiestāšanās regulāra neaizsargāta dzimumakta rezultātā 12 vai vairāku mēnešu ilgā periodā". Šajā darbā tiek lietots termins "sievietes neauglība" kā nespēja ieņemt bērnu un plašāks jēdziens "sievietes reproduktīvā mazspēja" kā nespēja ieņemt un / vai iznēsāt grūtniecību līdz termiṇam.

G̣enētiskā patoloǵija tiek atzīta par nozīmīgu sievietes reproduktīvās mazspējas iemeslu visos galvenajos veiksmīgas apaug̣̣ošanās un grūtniecības progresa faktoru līmeņos, sākot ar embrionālo, mātes (piemēram, endometrija) un kopīgo - placentas faktoru. Sievietes neauglības ǵenētisko cēloṇu meklēšana aizsākās 20. gadsimta piecdesmito gadu beigās, kad ar kariotipēšanas palīdzību tika atklāts Tērnera sindroms (Ford et al., 1959), un turpinās līdz šai dienai, pateicoties jaunu molekulāro metožu attīstībai un tehnologiskajiem sasniegumiem. Tomēr joprojām salīdzinoši maz ir zināms par vairuma sievietes neauglības gadījumu ǵenētisko izcelsmi, diemžēl vēl mazāk tiek ieviests klīniskajā praksē, kavējot individualizētas ārstēšanas progresu reproduktīvajā medicīnā.

Bez šaubām, 21. gadsimtu klīniskajā medicīnā un jo īpaši zinātnē var uzlūkot kā genomikas gadsimtu, jo galvenie sasniegumi bija iespējami, pateicoties slimību molekulāro mehānismu atklāšanai. Ģenētiskie testi kḷūst arvien pieprasītāki arī sievietes reproduktīvās mazspējas diagnosticēšanas un vadīšanas ietvaros. Diemžēl bieži vien var novērot atpalikšanu starp datiem, kurus iegūst, pateicoties jaunākajām tehnologijāam, un to klīnisko interpretāciju 
un lietojamību, kas ir saistîts ar katras genētiskās metodes īpatnībām, kā arī zināšanu trūkumu par molekulāro un genētisko sievietes reproduktīvās mazspējas patofiziolog̣iju. Viss minētais iztrūkstošu un / vai nepilnvērtīgu vadlīniju kontekstā, kas regulētu sievietes reproduktīvās genētikas jomu, palielina nepareizas pacientu vadības, psiholoǵiskā sloga un pārmērīgu izmaksu risku pacientiem, viṇu ǵimenes locekḷiem un pēcnācējiem.

\section{Darba mērḳis}

Demonstrēt mūsdien̄̄gu genomisko tehnolog̣iju lietošanu dažādās sievietes reproduktīvās mazspējas stadijās reālos klīniskajos vai pētījumu scenārijos, lai palielinātu pāra iespējas ieņemt veselu bērnu, uzlabotu ǵenētiskās testēšanas uzticamību agrīnas grūtniecības zaudēšanas gadījumā un atklātu dzemdes kakla nepietiekamības ǵenētisko etiologiju.

\section{Darba uzdevumi}

1. Izstrādāt pirmsimplantācijas ǵenētiskās testēšanas protokolus un salīdzināt divu pilna genoma amplifikācijas metožu veiktsēju dažādu embrija patolog̣iju analīzes ietvaros.

2. Izstrādāt mātes šūnu kontaminācijas novērtēšanas protokolu agrīni pārtraukušās grūtniecības materiāla ǵenētiskajai testēšanai.

3. Veikt dzemdes kakla funkcionēšanā iesaistīto gēnu sistemātisku analīzi, lai veicinātu nākamās paaudzes sekvencēšanas datu interpretāciju pacientiem ar dzemdes kakla nepietiekamību. 
4. Izmantojot nākamās paaudzes sekvencēšanu pacientu kohortā ar dzemdes kakla nepietiekamības izraisītām priekšlaicīgām dzemdībām, raksturot stāvokḷa ǵenētisko etiologiiju un identificēt gēnu variantus palielinošus dzemdes kakla nepietiekamības attīstības varbūtību.

\section{Darba hipotēze}

Mūsdien̄̄gas ǵenētiskās tehnolog̣ijas var veiksmīgi lietot dažādu genētisko patologiju, kas ietekmē sievietes reproduktīvo potenciālu, ticamai novērtēšanai, savukārt genētiskās testēšanas labas prakses vadlīniju un gēnu klīniskās validitātes novērtējuma trūkums traucē uzkrāto zināšanu klīnisko lietojamību sievietes reproduktīvās ǵenētikas jomā.

\section{Darba novitāte}

Darbs, kas ir aprakstīts 2. nodaḷā, atspoguḷo individualizētu pirmsimplantācijas embriju ǵenētiskās testēšanas protokolu izstrādi un šādas testēšanas ieviešanu Latvijāa kā arī apraksta divu plaši izmantoto pilna genoma amplifikācijas metožu veiktspējas salīdzinājumu, kas tika veikts pirmo reizi. Darbs, kas ir aprakstîts 3. nodaḷā, ir veltīts zināmai mātes šūnu kontaminācijas problēmai pārtraukušās grūtniecības ǵenētiskajā testēšanā un piedāvā pārstrādātu vienkāršu vizuālās un tehnologiiskās materiāla novērtēšanas un apstrādes protokolu, kas spēj veiksmīgi risināt problēmu. Darbs 4. nodą̧ā ne tikai apraksta nākamās paaudzes sekvencēšanas lietošanas rezultātus pacientiem ar izolētu dzemdes kakla nepietiekamību, kas tika veikts pirmo reizi, bet arī ietver visaptverošu un sistemātisku literatūras un gēnu analīzi par šo tēmu, kas arī tika veikts pirmo reizi. 


\section{$\bar{E}$ tika}

Šis pētījums ir saskaņā ar Helsinku êtikas principu deklarāciju, to ir apstiprinājusi Latvijas centrālās medicīnas ètikas komiteja (lūdzu, skatiet 1. un 2. pielikumus darba beigās). 


\section{Literatūras apskats}

\subsection{Sievietes reproduktīvās mazspējas ğenētiskie iemesli}

Sievietes gonādu attīstību un pareizu funkcionēšanu un līdz ar to sievietes reproduktīvo funkciju kopumā galvenokārt regulē koordinēta hipotalāmahipofīzes-gonādu ass darbība. Hipofīzes aktivitāte tiek stimulēta, pateicoties gonadotropīnu atbrīvojošam hormonam, ko producē hipotalāma neironi. Savukārt gonadotropīniem - folikulu stimulējošam hormonam (FSH) - un luteinizējošam hormonam (LH), kurus sintezē gonadotropās šūnas priekšējā hipofĩzē, pieder centrālā loma folikuloǵenēzes un ovulācijas regulācijā. FSH ir nepieciešams, lai katru mēnesi iesaistîtu un stimulētu attīstošās folikulu kohortas, bet LH aktivitāte mediē folikulu nobriešanas pēdējās stadijas un iniciē notikumu virkni, nodrošinošu pašu ovulāciju (McGee \& Hsueh, 2000). Folikulu nobriešanas gala stadijās granulozās folikulu šūnas kḷūst ligandjutīgas, pateicoties LH / horiona gonadotropīna receptoru attīstībai (Mitri et al., 2014). Rezultātā dzimumsteroīdi realizē hipotalāma un hipofīzes regulāciju, pateicoties atgriezeniskajai saitei (sk. 1.1. attēlu). Defekti vairākos gēnos, kas nodrošina hipotalāma-hipofīzes-gonādu ass darbību, ir aprakstīti kā sievietes reproduktīvās mazspējas iemesli (Beau et al., 1998; Layman, 2013). 


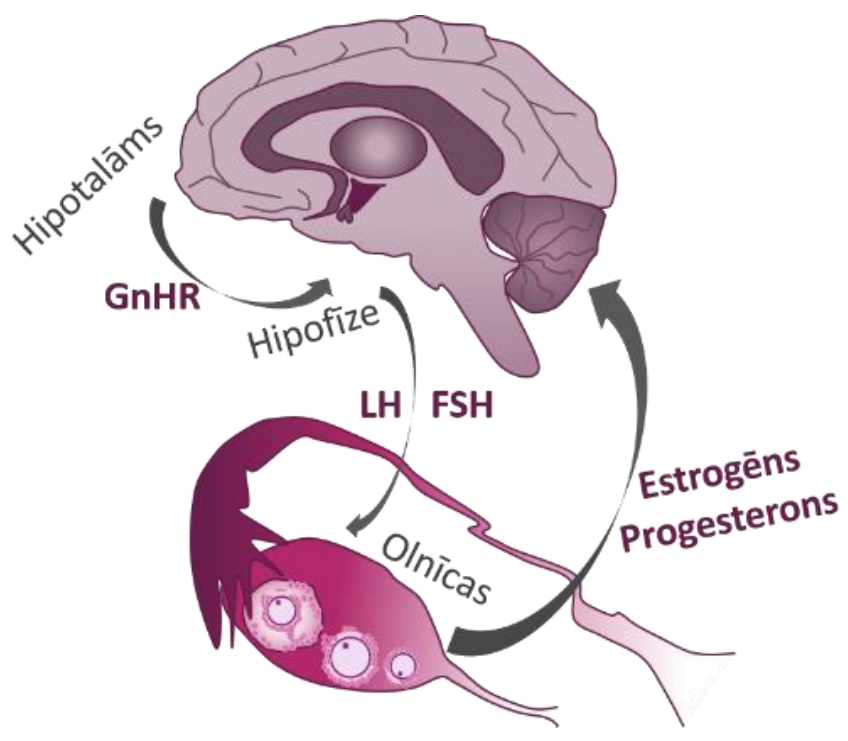

\section{1. attēls. Shematisks hipotalāma-hipofīzes-gonādu ass darbības principa attēlojums sievietes organismā (L. Voložonokas shēma)}

Hipotalāms producē gonadotropīnu atbrīvojošo hormonu (GnRH), kas stimulē luteinizējošā hormona (LH) un folikulu stimulējošā hormona (FSH) produkciju priekšejjā hipofìzes daivā; LH un FSH ietekmē estrogēna un progesterona produkciju olnīcās, kuri realizē atgriezenisko saiti uz hipotalāmu un hipofĩzi.

Zems gonadotropīnu līmenis plazmā, kā arī atgriezeniskās regulācijas pārrāvums sievietei izpaužas kā krūts dziedzeru attīstības traucējums / trūkums un hipoestrogēns menstruāciju trūkums un norāda uz to, ka defekts ir hipotalāma vai hipofīzes līmen̄̄ (parasti gonadotropīna atbrīvojošā hormona darbības traucējums). Ja pacienta oža nav traucēta, tad šādu stāvokli dēvē par hipogonadotropo hipogonādismu, papildus ožas traucējums liecina par Kalmana sindromu. Pretēju stāvokli - hipergonadotropo hipogonādismu - raksturo palielināti FSH un LH līmeņi, liecinot par to, ka defekts ir gonādu (sievietes organismā olnīcu) līmen̄i. Aizdomās par hipergonadotropo hipogonādismu ir jāatceras par Tērnera sindromu, ko izraisa $\mathrm{X}$ hromosomas monosomija vai mozaīkveida monosomija (ICD-10 Q96.9) (Layman, 2013). 
Attīstoties mākslīgās apaugḷošanas tehnologijāam un pateicoties to plašajam lietojumam visā pasaulē, oocītu attīstības, apauglošanās un embrija attīstības agrīnais periods var tikt detalizēti novērots un pētīts, veicinot jaunu fenotipu un gēnu atklāšanu, kas izraisa sievietes reproduktīvo mazspēju (Sang et al., 2019). 1.1. tabulā ir apkopoti gēni, kas iesaistīti sievietes reproduktīvās mazspējas attīstībā pirmsgonādu līmen̄i, gonādu līmenī, kā arī gēni, kas ietekmēe sievietes reprodukciju, darbojoties ārpus hipotalāma-hipofīzes-gonādu ass. 


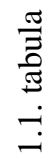

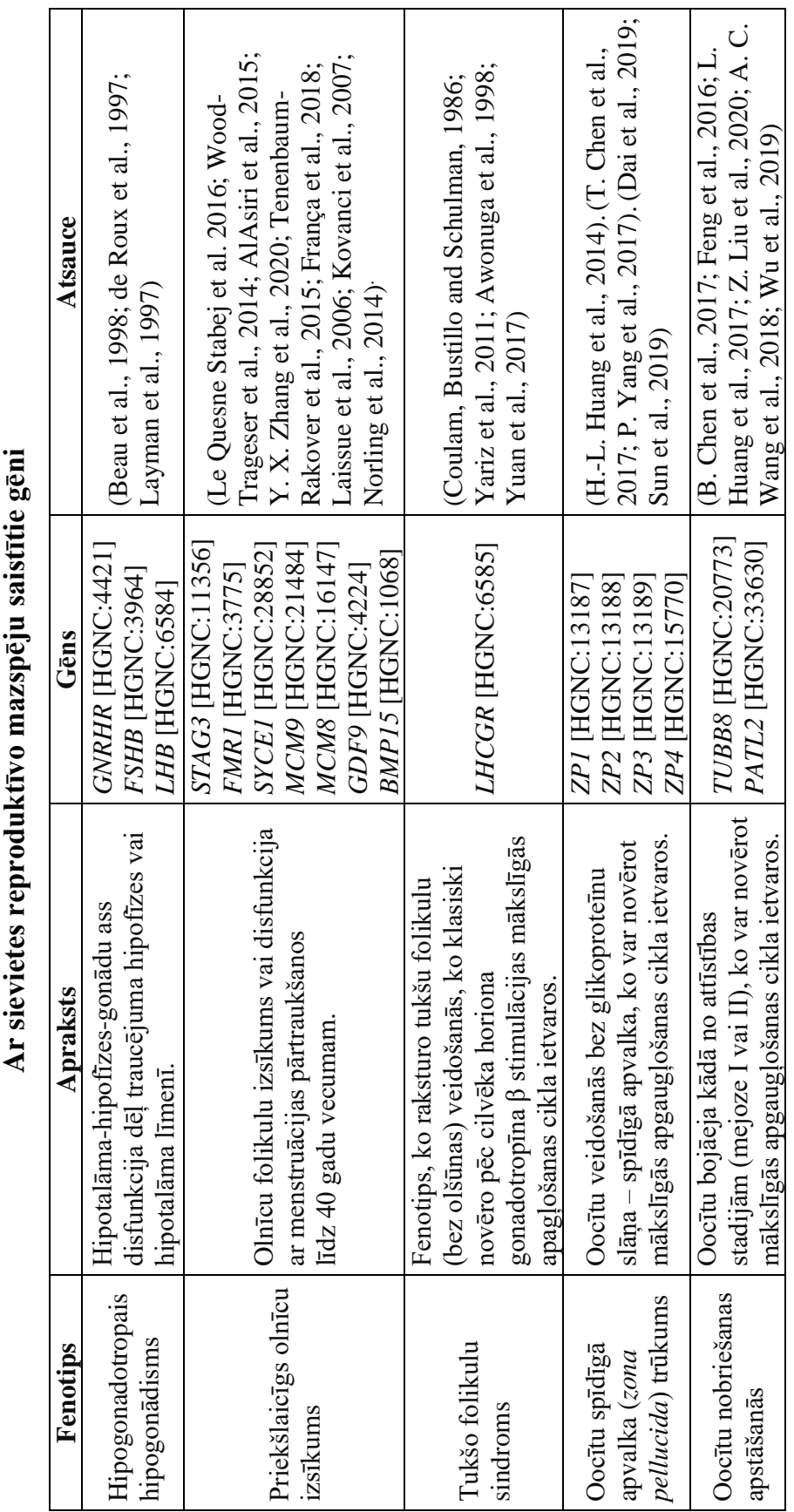




\begin{tabular}{|c|c|c|c|c|c|c|c|}
\hline 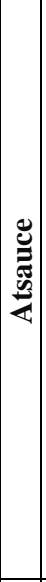 & 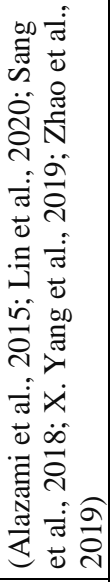 & 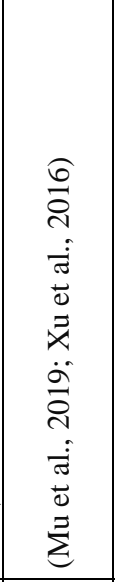 & 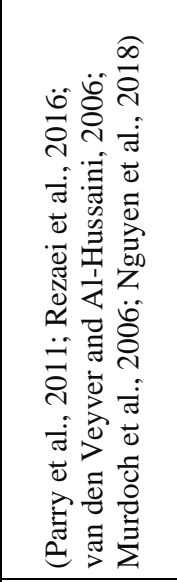 & 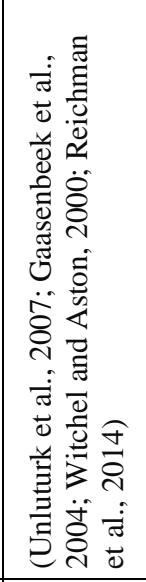 & 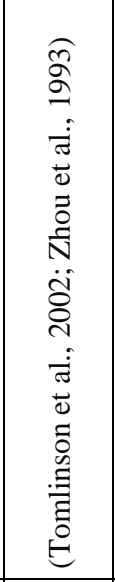 & 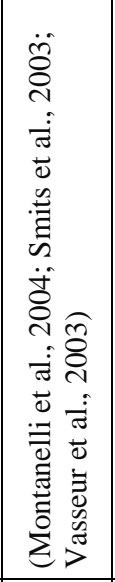 & 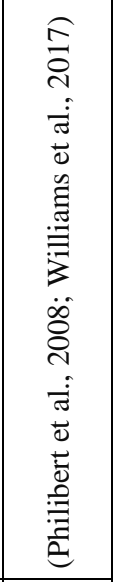 \\
\hline & 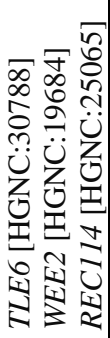 & 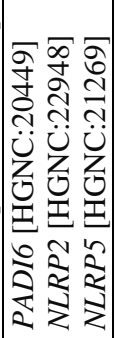 & 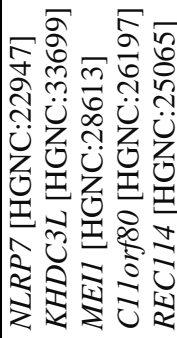 & 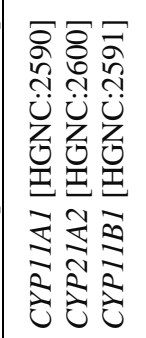 & 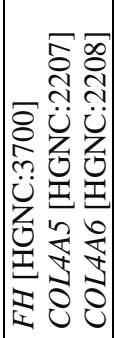 & 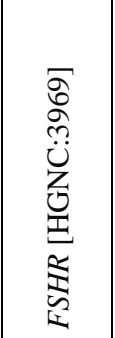 & 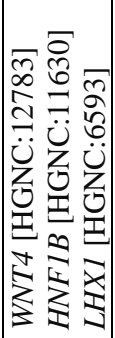 \\
\hline & 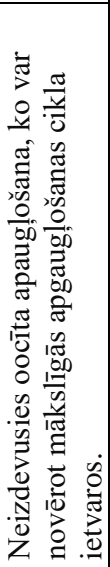 & 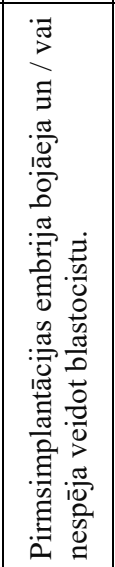 & 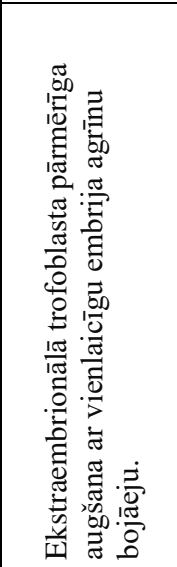 & 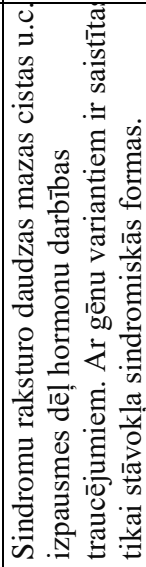 & 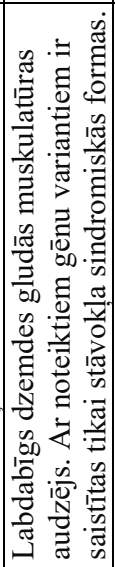 & 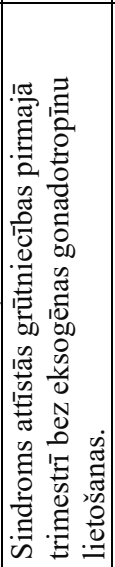 & 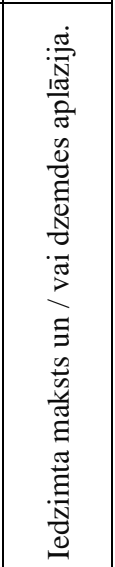 \\
\hline 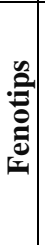 & 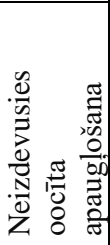 & 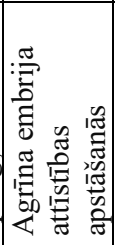 & 焉 & 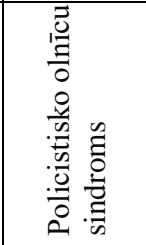 & 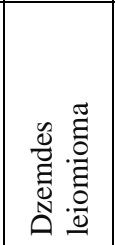 & 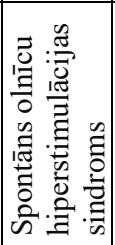 & 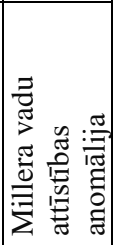 \\
\hline
\end{tabular}




\section{2. Ģenētiskā testēšana diagnostikas ietvaros}

Zinātniskie pētījumi ir brīvi, izvēloties konkrētas pētǐšanas metodes, izstrādājot secinājumus, kā arī tiem nav atbildības pacientu priekšā, turpretī ǵenētiskās testēšanas galvenie uzdevumi diagnostikas ietvaros ir diezgan stingri: noskaidrot patieso slimības g̊enētisko cēloni / risku; skaidri noteikt testēšanas metodolog̣ijas ierobežojumus; identificēt radiniekus ar paaugstinātu konkrētā stāvokḷa attīstības risku; identificēt stāvokḷus, kas var iedzimt pēcnācējiem; identificēt stāvokḷus, pakḷaujamus mērḳa terapijai; un, kas īpaši attiecas uz cilvēka reprodukciju, optimizēt mākslīgās apaugḷošanas lietošanu.

Šobrīd ir izveidotas rekomendācijas ǵenētiskajam prekoncepcijas nesēju skrīningam, ieskaitot tā piemērošanai mākslīgās apaugḷošanas ietvaros (Edwards et al., 2015), taču pastāv zināms vadlīniju vai komitejas atzinumu trūkums par genētisko testēšanu sievietes reproduktīvās mazspējas gadījumā. Līdz ar to klīnikā tikai l,oti ierobežots skaits specifisku ǵenētisko izmeklējumu tiek piemērots, lai analizētu hromosomālās aberācijas vai viena gēna defektus, kas var būt saistīti ar sievietes reproduktīvajiem fenotipiem (Cariati et al., 2019). Piemēram, klasiski tiek nozīmēta kariotipēšana, lai atklātu tādas hromosomālās izmaiņas kā, piemēram, Tērnera sindroms vai diferencētu Svaiera sindromu fenotipiskās sievietēs ar kariotipu 46,XY. Turklāt kariotipēšana ir praktiski vienīgā metode, kas piemērojama, lai atklātu līdzsvarotas kariotipa izmaiņas; kā zināms, strukturālas hromosomu aberācijas atrod $\sim 5 \%$ sieviešu ar nesindromisku reproduktīvo mazspēju (Gekas et al., 2001). Nākamā labi zināmā ǵenētiskā izmeklēšana ar stabilu lomu sievietes neauglībā ir CGG atkārtojumu ekspansijas analīze gēnā $F M R 1$, kas ir saistīta ar priekšlaicīgu olnīcu izsīkšanu.

Papildus pastāv daži genētiskie testi, piemērojami kādai specifiskai problēmai sievietes reproduktologijā vai reproduktīvo tehnologiju ietvaros. 


\subsubsection{Pirmsimplantācijas embriju ġenētiskā testēšana}

Sieviešu daudzums vecumā no 15 līdz 49 gadiem, kuras jebkad ir izmantojušas mākslīgās apaugḷošanas pakalpojumus, Amerikas Savienotajās Valstīs ir 12,7\%. Aptuveni 1,9\% no visiem zīdainiem, kas katru gadu dzimuši ASV, tiek ieņemti, izmantojot mākslīgo apaugḷošanu (Singh, 2004). Kopš piedzimusi Luīze Brauna - pasaules pirmais "mēǵenes zīdainis" - 1978. gadā (Steptoe \& Edwards, 1978), reproduktīvās tehnoloǵas ir ievērojami uzlabojušās tehnoloǵiski un metodoloǵiski. Dzimstības rādītāji, izmantojot in vitro apaugḷošanu, svārstās no $27 \%$ līdz 55\% atkarībā no pacienta vecuma grupas un izmantotās metodes (Dahdouh et al., 2015). Neveiksmīga neauglības ārstēšana ir viena no galvenajām klīniskās reprodukcijas problēmām. Viens no galvenajiem reproduktīvo tehnolog̣iju sasniegumiem ir pirmsimplantācijas embriju ǵenētiskā testēšana (PG̣T), kas tagad rutīni tiek izmantota, lai analizētu embriju ġenētisko profilu. Sākotnēji PG̣T tika ieviesta, lai analizētu embrijus no zināmiem monogēno traucējumu nesējiem (PG̣T-M), bet vēlāk attīstìjās, lai pārbaudītu visu hromosomu komplektu kā embriju selekcijas rīku ar cerību palielināt dzimstību pēc embrija pārneses (PG̣T-A) (Theobald et al., 2020).

\subsubsection{Pārtraukušās grūtniecības ǵenētiskā testēšana}

Vairākas pieejas un metodes tiek lietotas pārtraukušās grūtniecības materiāla genētiskajai testēšanai, ieskaitot klasiskās citoǵenētikas tehnikas (kariotipēšana, fluorescentā in situ hibridizācija), uz PḲR balstītas metodes un genomiskās tehnologijas, kā salīdzinošā genoma hibridizācija uz mikročipiem vai nākamās paaudzes sekvencēšana. Visām tām ir ierobežojumi, piemēram, veiksmīgas kariotipēšanas priekšnoteikums ir dzīvotspējīgu horija audu klātbūtne primārajā biologiiskajā materiālā (Lomax et al., 2000). Būtiski, ka visas metodes var izdot maldinošus rezultātus, ja mātes šūnu kontaminācija paraugā 
netiek ņemta vērā. Mātes šūnu kontaminācijas problēma pārtraukušās grūtniecības materiāla testēšanā ir aprakstîta laboratorijas praksē (Jarrett et al., 2001; Shen et al., 2016), tomēr tā joprojām rada apgrūtinājumu analīžu interpretēšanā un rezultātu ziņošanā, un metodes, kas dod iespēju atpazīt un risināt šo jautājumu konvencionāli, nav plaši adaptētas, kā redzam no zinātniskās literatūras.

\subsection{Literatūras apskats: kopsavilkums}

Pēdējās desmitgadēs ir gūti zināmi panākumi sieviešu reproduktīiās mazspējas molekulārā un genētiskā profila atšifrēšanā. Tomēr šo zināšanu izmantošana klīniskajā praksē joprojām ir apgrūtināta un sadrumstalota (Cariati et al., 2019), ko varētu skaidrot ar: i) plašu un dažkārt pārklājošos reproduktīvo fenotipu spektru un to heterogenitāti, ii) plašo genomisko tehnologijiju un testēšanas pieeju klāstu, no kuriem katrs ir saistīts ar dažādiem ierobežojumiem un īpatnībām. Līdz ar to pētījuma mērķis ietvēra izstrādāt uzticamus protokolus, kas balstītos uz modernu genomisko tehnolog̣iju izmantošanu noteiktos sievietes reprodukcijas fenotipos / stadijās, pārvarēt šo tehnologiju trūkumus un demonstrēt to piemērotu izmantošanu reālos klīniskajos vai pētījumu scenārijos.

Tādējādi 2. darba nodaḷa tika veltīta daudzfaktoru pirmsimplantācijas embriju testēšanas protokolu izstrādei, kurā tika parādīts divu pilna genoma amplifikācijas metožu veiktspējas salīdzinājums dažādu genoma struktūru testēšanā ar četrām dažādām tehnologijām. Darba 3. nodaļa tika veltīta mātes šūnu kontaminācijas novērtēšanas protokola izstrādei un ieteikumu formulēšanai, lai uzlabotu dažādas kvalitātes pārtraukušās grūtniecības materiāla apstrādes darbplūsmu preanalītiskajos un analītiskajos posmos. Visbeidzot 4. darba nodaḷā tika analizēts nesindromiskas dzemdes kakla nepietiekamības genētiskais profils, izmantojot nākamās paaudzes sekvencēšanu. 


\section{Divu pilna genoma amplifikācijas tehniku veiktspējas salīdzinājums pirmsimplantācijas embriju genētiskajā testēšanā}

Publicēts kā:

Ludmila Volozonoka, Dmitry Perminov, Liene Kornejeva, Baiba Alkšere, Natālija Novikova, Evija Jokste Pīmane, Arita Blumberga, Inga Kempa, Anna Miskova, Linda Gailīte, Violeta Fodina, 2020. Performance comparison of two whole genome amplification techniques in frame of multifactor preimplantation genetic testing. Journal of assisted reproduction and genetics, 35(8), 1457-1472. DOI: 10.1007/s10815-018-1187-4.

Personīgais ieguldījums:

Mans personīgais ieguldījums šajā darbā ietver embriju testēšanas protokolu izstrādi, testēšanai izmantojamo metožu izvēli, praktisko izmeklējumu veikšanu trim ǵimenēm no deviņām, datu interpretāciju, pilna genoma amplifikācijas metožu salīdzināšanu, publikācijas uzrakstǐšanu. Lūdzu, skatiet visu līdzautoru parakstītus apliecinājumus dotās publikācijas izmantošanai manā promocijas darbā (3. pielikums).

\subsection{Ievads}

Pirmsimplantācijas ǵenētiskā testēšana ir alternatīva prenatālajai testēšanai pāriem ar paaugstinātu risku kādas ǵenētiskās patoloğijas nodošanai pēcnācējiem. Laika gaitā PG̣T ir piedzīvojusi nozīmīgas metodoloğijas izmaiṇas, sākot no polārḳermenīšu un blastomēru analīzes līdz tagad plaši lietojamai trofektodermas biopsijai ar tai sekojošu blastocistas sasaldēšanu (Renwick et al., 2006). Taču, neskatoties uz tehnoloǵiskajiem uzlabojumiem, PG̣T protokolu izstrāde ir sarežğīta amplifikācijas neizdošanās dēḷ, parauga kontaminācijas un alēles / lokusa izkrišanas fenomena dēl, tas raksturīgs visiem vienas vai dažu 
šūnu PĶR testiem, tā ietekmējot PG̣T testēšanas sistēmas drošumu. Alēles izkrišanas incidence variē, bet ārkārtas gadījumos tā ir skārusi 20\% amplifikāciju un pagātnē izraisījusi vairākas nepareizas diagnozes (Capalbo et at., 2016). Pilna genoma amplifikācijas metodes izvēle arī nav viennozīmīga problēmu turpmāko testēšanas metožu interpretācijā dēl, piemēram, īso tandēma atkārtojumu analīzē ar fluorescento PĶR vai salīdzinošās genoma hibridizācijas uz mikročipiem (Rechitsky et al., 2015). Šobrīd ir pieejamas vairākas pilna genoma amplifikācijas metodes (Zheng et al., 2011), piemēram, deǵenerētu oligonukleotīdu praimeru metode (Telenius et al., 1992) vai praimeru pagarināšanas tehnologija (L. Zhang et al., 1992). Līderpozīcijas tirgū ieņem Rubicon Genomics izstrādāta SurePlex PĶR tehnologiija (S. U. Chen et al., 2008; Uda et al., 2007) un izotermālas (ne PĶR) Phi-29 polimerāzes sintēzes metode MDA (angl. multiple displacement amplification) (Handyside et al., 2004). Taq DNS polimerāzes izmantošana PĶR metodēs limitē fragmentu garumu līdz 3kb. Savukārt Phi-29 polimerāze generē fragmentus līdz $100 \mathrm{~kb}$, un tai piemīt 3' $\rightarrow 5^{\prime}$ eksonukleāzes kḷūdu nolasǐšanas aktivitāte. Abām metodēm ir priekšrocības un trūkumi, līdz ar to nav skaidrs, kuras izvēli varētu prioritizēt, izstrādājot PG̣T protokolos (Zheng et al., 2011). Arī PG̣T savas specifikas dēl, neskatoties uz atzītiem metodes lietošanas ieguvumiem, joprojām nav standartizēta un regulēta metode salīdzinājumā ar citām testēšanas metodēm (Harton et al., 2011).

Ṇemot vērā iepriekš minēto informāciju, šā pētījuma mērḳis bija izstrādāt individualizētu efektīvu un uzticamu daudzfaktoru embriju testēšanas protokolu un demonstrēt divu pilnas genoma apmplifikācijas metožu veiktspējas salīdzinājumu četrās dažādās tehnologijijās - nosakot īsos tandēma atkārtojumus, Sangera sekvencēšanā, salīdzinošajā genoma hibridizācijā uz mikročipiem un SNaPshot tehnoloǵijā. 


\subsection{Materiāli un metodes}

\subsubsection{Pirmsklīniska sagatavošanās PĢT ciklam}

Deviņi pāri ar apstiprinātu viena gēna patolog̣iju tika konsultēti par PG̣T procedūru, olnīcu stimulāciju, olšūnu aspirāciju un mākslīgo apaglošanu. Saistītie mikrosatelītu marķieri, kas atrodas blakus interesējošajam gēnam, tika lokalizēti caur Kalifornijas Universitātes Santa Kruzas genoma pārlūkprogrammu (https://genome-preview.ucsc.edu/index.html). Visiem lokusiem tika dizainēti praimeri divpakāpju multipleksa PĶR testēšanas sistēmai, praimeru specifiskums tika nodrošināts, izmantojot "Primer-BLAST" (Ye et al., 2012). No PG̣T ǵimenes locekḷu perifērajām asinīm tika izolēta DNS, izmantojot standarta procedūru [Qiagen]. Analizējot mikrosatelītus, tika sastādīti gimenes haplotipi. Kartā gimenē 6-13 $(8.1 \pm 2.5)$ informatīvi vai pusinformatīvi marķieri tika atlasīti turpmākai embriju analīzei (sk. 2.1. tabulu). Slimību izraisošā gimenes varianta apstiprināšana tika veikta, izmantojot Sangera sekvencēšanu (Sambrook \& W Russell, 2001) viena nukleotīda variācijas gadījumā un izmantojot fragmentu garuma analīzi trinukleotīdu ekspansijas gadījumā [Applied Biosystems, ASV].

\subsubsection{Klīnisko gadījumu analīze}

Visu iegūto embriju trofektodermas biopsijas DNS materiāls tika pavairots, izmantojot pilna genoma amplifikāciju - daḷai tika lietota MDA tehnologija [Illumina, ASV] un dalai SurePlex [Illumina, ASV] (sk. 2.2. tabulu). Embriju haplotipēšanai izmantoja marḳierus, atlasītus iepriekšējā solī, mutācijas lokusa analīzi veica, izmantojot Sangera vai SnaPshot analīzi [Applied Biosystems, ASV]. HTT gēna (OMIM:613004) CAG atkārtojumu skaits (RCV000030659, HGVS nomenklatūra - NM_002111.6(HTT):c.53_55[(41_?)] (p.Gln40(41_?)) tika noteikts ar kapilāra elektroforēzes metodi. Embriju 
hromosomu analīze tika veikta, ievērojot ražotāja [24Sure, Illumina, ASV] protokolu. 
ํ.

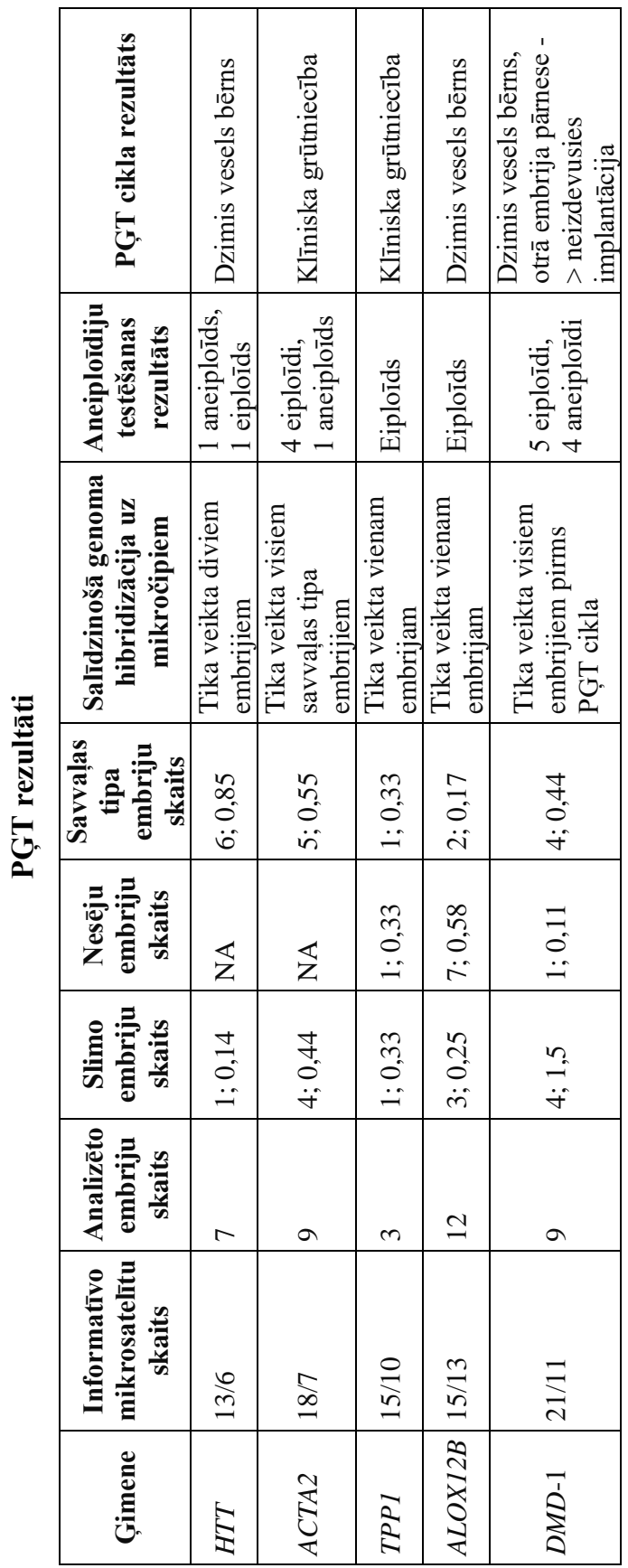


覃

\begin{tabular}{|c|c|c|c|c|}
\hline 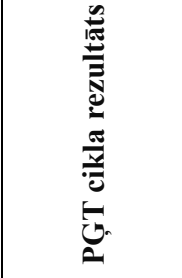 & 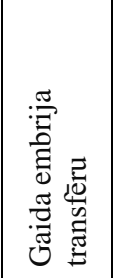 & 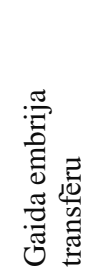 & & \\
\hline 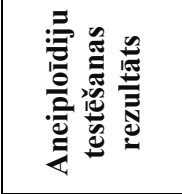 & 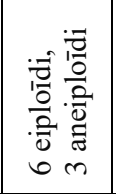 & 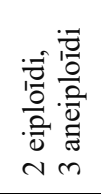 & & \\
\hline 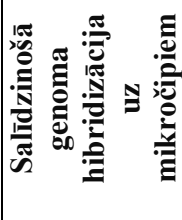 & 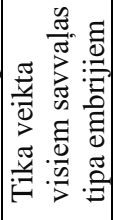 & 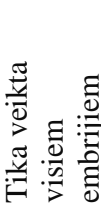 & & \\
\hline 竞 & $\begin{array}{l}\tilde{n} \\
0 \\
0 \\
\sigma\end{array}$ & $\begin{array}{l}\tilde{O} \\
0 \\
-\end{array}$ & $\mid \begin{array}{l}0 \\
0 \\
00 \\
00 \\
0 \\
0\end{array}$ & \\
\hline 漓滈产 & $\begin{array}{l}\text { ते } \\
\text { o } \\
\ddot{n}\end{array}$ & $\begin{array}{l}\infty \\
0 \\
\ddot{f}\end{array}$ & 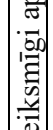 & 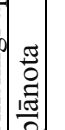 \\
\hline 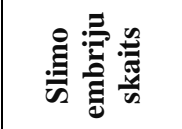 & $\begin{array}{l}\frac{\infty}{0} \\
\ddot{m}\end{array}$ & $\begin{array}{l}0 \\
\dot{0}\end{array}$ & $\mid \begin{array}{c}0 \\
: 0 \\
0 \\
0 \\
0 \\
0 \\
0 \\
0=0\end{array}$ & 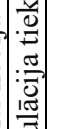 \\
\hline 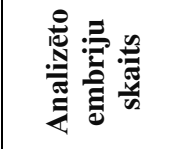 & I & $n$ & $\left|\begin{array}{c|}0 \\
0 \\
0 \\
0 \\
0 \\
0 \\
0 \\
z\end{array}\right|$ & 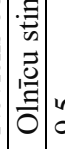 \\
\hline 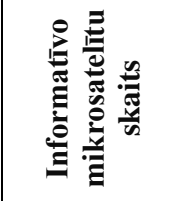 & $\widehat{E}$ & $\stackrel{\infty}{n}$ & $\frac{5}{y}$ & $\stackrel{2}{2}$ \\
\hline 节 & 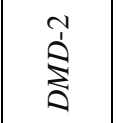 & $\underset{ত}{0}$ & & $\frac{⿱ 亠 乂}{z}$ \\
\hline
\end{tabular}


$\frac{\pi}{3}$
กิ
ก

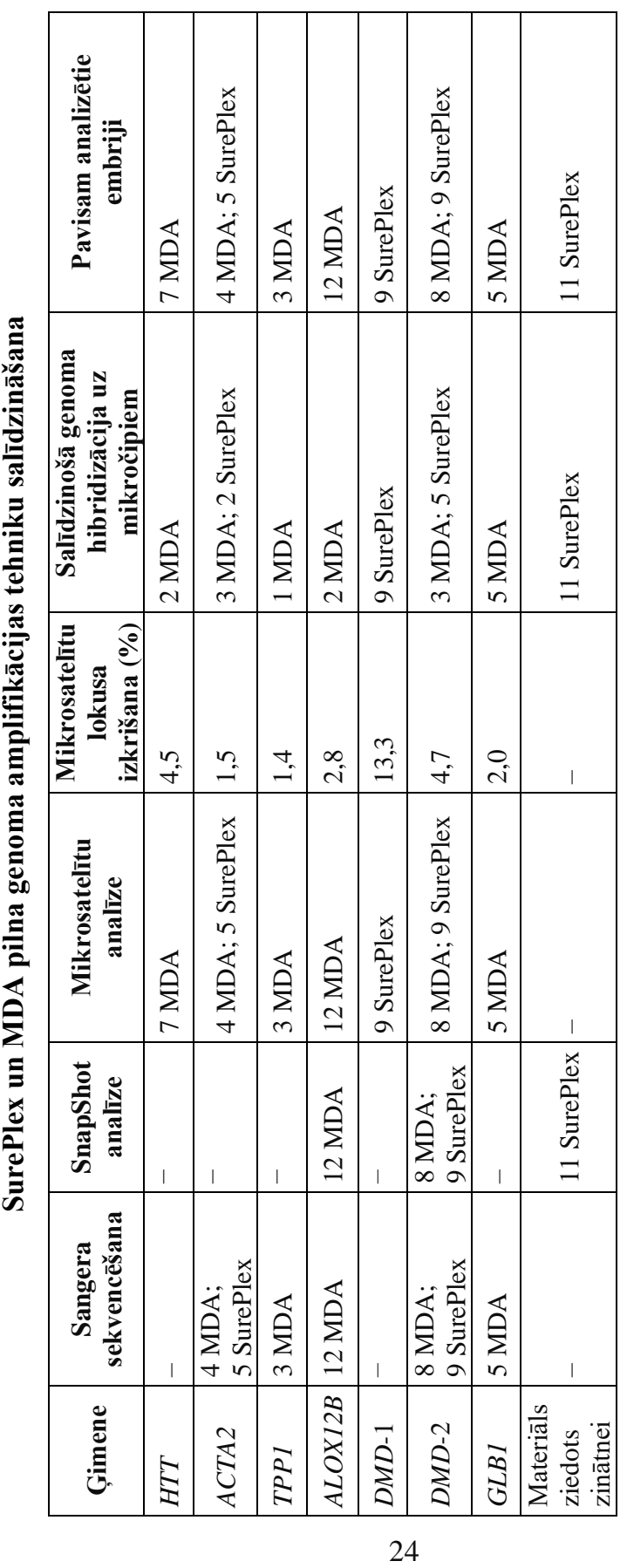




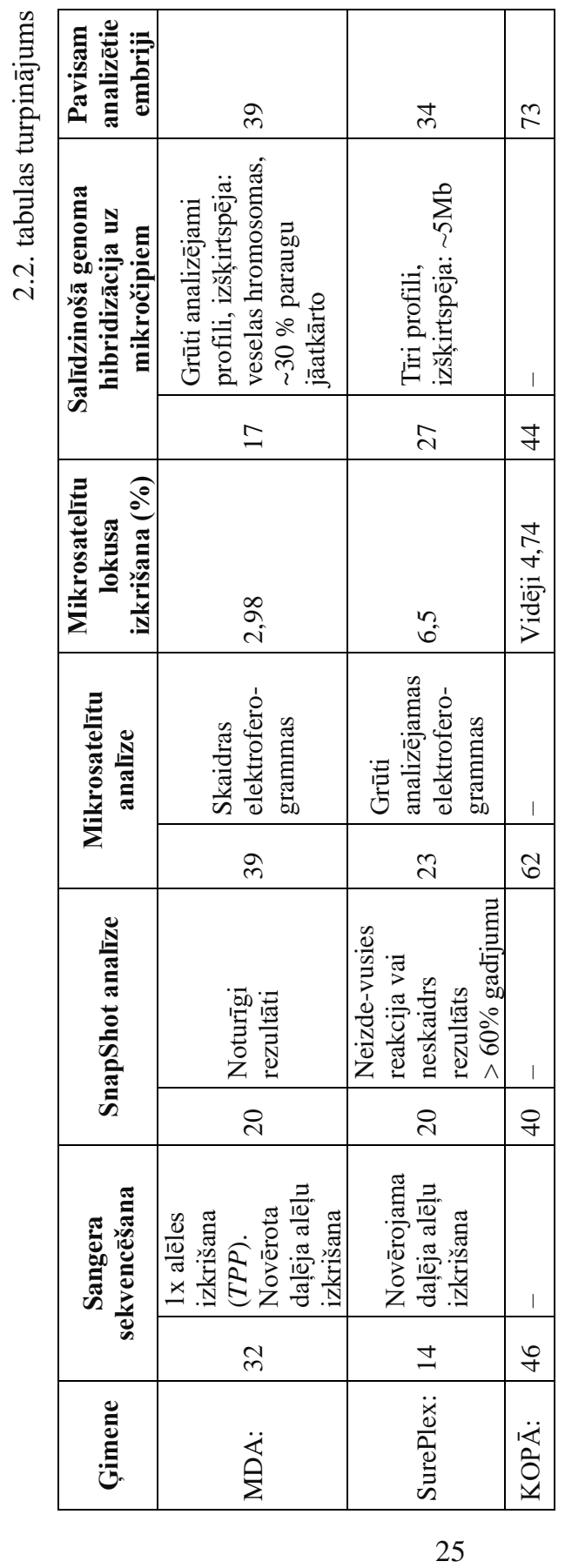




\subsection{Rezultāti}

\subsubsection{Divu pilna genoma amplifikācijas metožu salīdzinājums}

Abas pilna genoma amplifikācijas metodes tika analizētas, izmantojot četras dažādas tehnolog̣ijas - Sangera sekvencēšanu, SNaPshot analīzi, fragmentu garuma analīzi un salīdzinošo genoma hibridizāciju uz mikročipiem (sk. 2.2. tabulu). Mūsu rezultāti parāda, ka abas metodoloǵijas rezultējas dal̦ējā alēḷu izkrišanā, ja tiek veikta Sangera sekvencēšana (sk. 2.1. attēlu). Slimību izraisošo alēles vājo amplifikāciju var atšķirt kā zema līmeņa pīḳi citādi skaidrā profilā (nav fona). Viens TPPl paraugs rezultējās pilnīgā varianta alēles izkrišanā, neskatoties uz divpakāpju amplifikācijas pieeju. 

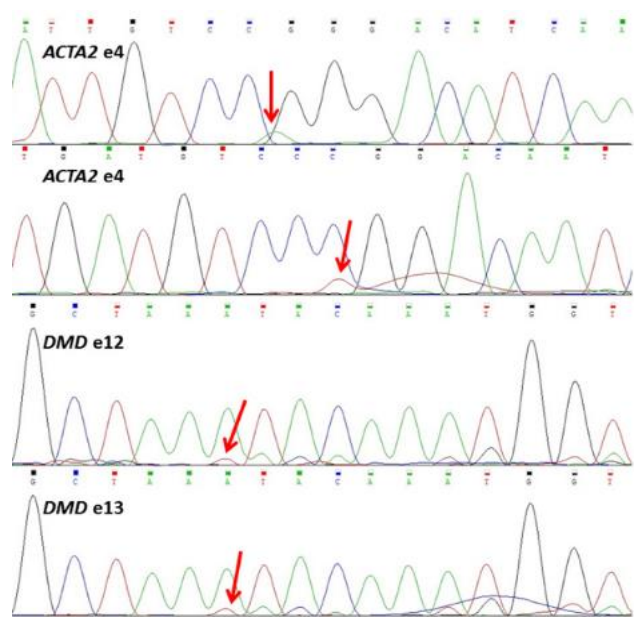

2.1. attēls. Sangera sekvencēšanas profili ar dažādām pilna genoma amplifikācijas metodēm

ACTA2 embrijs e4 tika amplificēts ar SurePlex (augšējā secība iegūta ar tiešo praimeri, apakšējā ar reverso). Sarkanās bultiņas norāda uz varianta alēles daḷēju izkrišanu. Dotā embrija haplotipa analīze atbilst heterozigotam genotipam. DMD- 2 embriji e12 un e13 tika amplificēti ar MDA metodi. Abas elektroferogrammas attēlo secības, iegūtas ar tiešo praimeri. Sarkanās bultiņas norāda uz varianta alēles daḷēju izkrišanu - viena nukleotīda delēciju. Izmainītā alēle ir nosakāma tikai kā vājš pīḳis, kas līdzīgs fonam.

Doto embriju haplotipa analīze atbilst heterozigotam genotipam.

Tālāk mēs bijām ieinteresēti salīdzināt abu amplifikatoru veikumu, izmantojot SNaPshot genotipēšanas tehnologijiju (sk. 2.2. attēlu). MDA produkts uzrādīja ar Sangera sekvencēšanu salīdzināmus rezultātus, visi genotipi sakrita, savukārt SurePlex produkta testēšana atkārtoti neuzrādīja interpretējamus profilus vairāk nekā 60\% gadījumu (dati nav attēloti). 

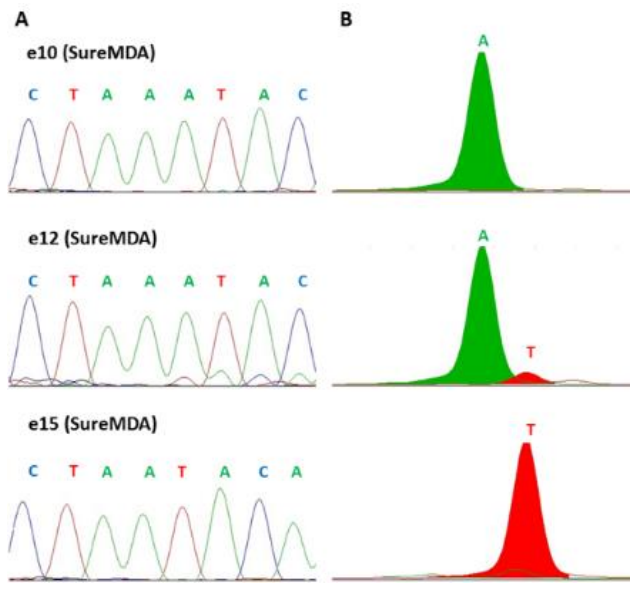

\section{2. attēls. DMD-2 embriju rezultāti}

MDA tehnoloǵijas veikums Sangera sekvencēšanā (A) un SnaPshot tehnoloǵijā

(B). Profili pilnībā sakrīt, heterozigots embrijs e12 uzrāda dạ̣ēju alēles izkrišanu abos gadījumos.

Dažādas abu amplifikācijas metožu dabas dēl tie rezultējās piln̄̄gi atšķirīgos elektroferogrammu profilos, genotipējot mikrosatelītus ar PĶR fragmentu garuma noteikšanas metodi, ko redz kapilāra elektroforēzē (sk. 2.3. attēlu). Izteikti artificiāli pīḳi parādās polimerāzes enzīma "slīdēšanas" SurePlex amplifikācijas laikā un tam sekojošas pārākuma amplifikācijas nepareiza garuma fragmentos. Šādos gadījumos izškirt īsto embrija genotipu iespējams tikai, paralēli analizējot arī vecāku genomisko DNS. 


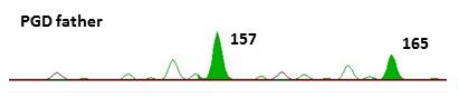

PGD father

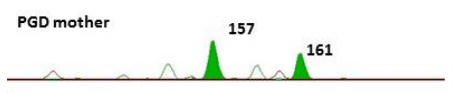

PGD mother
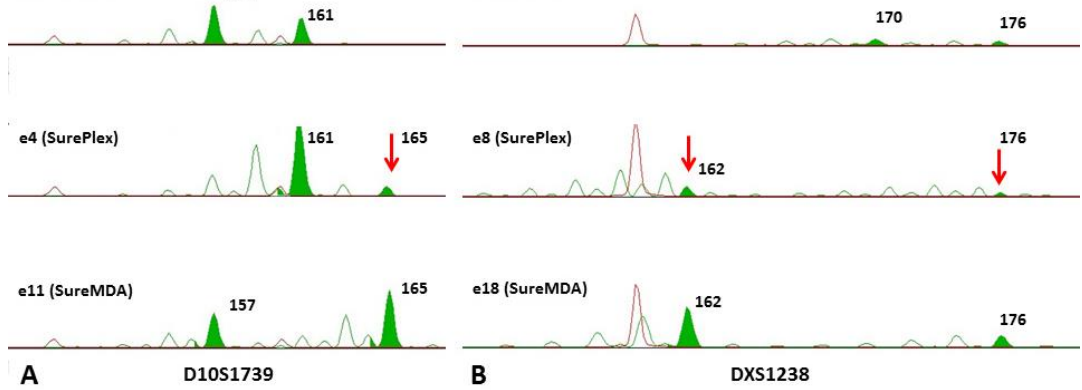

2.3. attēls. Mikrosatelītu D10S17390 (A) un DXS1238 (B) genotipēšana, izmantojot kapilāra elektroforēzi

İsteno alẹḷu daḹja izkrišana, izmantojot SurePlex metodi, ir parādīta ar sarkanām bultiņām, lielākā daḷa izteikto pịḳu ir artefakti. 


\section{Mātes šūnu kontaminācijas izraisītas nepareizas diagnozes mazināšana agrīnas grūtniecības zaudēšanas genētiskajā testēšanā}

Publicēts kā:

Ludmila Volozonoka, Linda Gailite, Dmitrijs Perminov, Liene Kornejeva, Violeta Fodina, Inga Kempa, and Anna Miskova, 2020. Reducing misdiagnosis caused by maternal cell contamination in genetic testing for early pregnancy loss. Systems Biology in Reproductive Medicine, 66(6), 410-420. doi: 10.1080/19396368.2020.1827081.

Personīgais ieguldījums:

Mans personīgais ieguldījums šajā darbā ietver pētījuma dizaina izstrādi, visu paraugu praktisku testēšanu, datu interpretāciju, publikācijas uzrakstī̌sanu. Lūdzu, skatiet visu līdzautoru parakstītus apliecinājumus dotās publikācijas izmantošanai manā promocijas darbā (4. pielikums).

\subsection{Ievads}

Grūtniecības zaudēšana ir traumējoša pieredze pacientam, kā arī ir klīniska problēma dzemdniecības un ginekologiijas praksē. Novērojams, ka pārtraukušos grūtniecību skaits pieaug, īpaši attīstītajās valstīs, kur palielinās vidējais iedzīvotāju vecums un attiecīgi palielinās vidējais grūtnieces vecums (Heazell et al., 2018). Galvenā loma pārtraukušās grūtniecības etiologijijā ir augḷa hromosomālajām aberācijām, lielākā daḷa augḷu ar mainītu kariotipu iet bojā pirmajās grūtniecības nedēlāas (Davis et al., 2017; Romero et al., 2015). Koncepcijas produktu analīze ir klīniski svarīga, lai noskaidrotu agrīnas grūtniecības zaudēšanas cēloni un pielāgotu klīnisko taktiku nākamajā dabiskajā vai asistētā grūtniecības ieņemšanā. Pašlaik ir pieejamas dažāasas metodes 
hromosomu aneiplōidiju un strukturālo pārkārtojumu noteikšanai koncepcijas materiālā. Visām metodēm ir zināmi trūkumi, taču visas tehnolog̣ijas var izdot maldinošus rezultātus, ja netiek ņemta vērā mātes DNS kontaminācija (parasti dēvēta par mātes šūnu kontamināciju). Literatūrā ir aprakstīta tendence palielinātam normālas sievietes kariotipa ziņojumu daudzumam salīdzinājumā ar normāla vīrieša kariotipa ziņojumiem (Bell et al., 1999; Jarrett et al., 2001; Lathi et al., 2014). Tomēr ne visas laboratorijas risina šo svarīgo jautājumu un pievēršas tā etiologiijai (Nikitina et al., 2005).

Lai gan pastāv vairāki izskaidrojumi mainītam dzimumu sadalījumam pārtraukušās grūtniecības materiālā (Jarrett et al., 2001) kā, piemēram, neatpazīta molāra 46,XX grūtniecība, ar X-sistītas letālas mutācijas, kā arī dzimumhromosomu analīzes neizdošanās hromosomu preparātos (Eiben et al., 1990; Hassold et al., 1983), pētījumi demonstrē, ka līdz pat 59\% normāla sievietes kariotipa gadījumu ir saistāmi ar mātes šūnu kontamināciju (Jarrett et al., 2001; Lathi et al., 2014; Romero et al., 2015). No literatūras var secināt, ka pastāv ierobežota izpratne par koncepcijas materiāla analīzei izmantoto metodiku tehniskajiem ierobežojumiem un kritiskajiem aspektiem materiāla testēšanā. Līdz ar to darba mērḳis ir izstrādāt koncepcijas produktu testēšanas protokolu, kā arī formulēt materiāla apstrādes, testēšanas un ziņošanas ieteikumus. 


\subsection{Materiāli un metodes}

\subsubsection{Pacienti un pārtraukušās grūtniecības materiāla hromosomu analīze}

Pētījumā tika iekḷautas pacientes ar grūtniecības pārtraukšanos pirms 13. grūtniecības nedēlas. Kopumā pētījumā tika iekḷauti 86 paraugi. Mātes šūnu kontaminācijas genētiskai analīzei perifēro asiṇu paraugi tika iegūti no 47 sievietēm. Primārā biologiskā materiāla parauga vizuālais izskats tika reǵistrēts šādi: "labas kvalitātes horions" - ja vizualizēja tipisku horija bārkstiņu morfolog̣iju; "nekvalitatīvs horions" - ja novēroja audu macerācijas pazīmes un tikai dažas bārkstiņas; "horiju nevizualizē" - ja horija bārkstiņas nesaskatīja. Hromosomu analīzi veica visiem paraugiem ar salīdzinošo genoma hibridizāciju uz mikročipiem, ievērojot ražotāja protokolu [24sure; Ilumina, ASV].

\subsubsection{Mātes šūnu kontaminācijas ǵenētiskās testēšanas protokola izstrāde}

Mātes šūnu kontaminācijas testēšanas sistēma iekḷāva 14 mikrosatelītu, $A M E L$ un SRY reǵionu analīzi ar fluorescento PĶR. Visi 47 DNS paraugu pāri tika testēti, rezultāti klasificēti šādi: "kontaminācijas pazīmes" - ja elektroferogrammā detektēja trīs pīķus (vai divus, ja māte vai auglis bija homozigots); "tikai mātes genoms" - ja perifēro asiṇu parauga genotips pilnībā sakrita ar pārtraukušās grūtniecības materiāla genotipu; "nav kontaminācijas" ja augḷa genotipu varēja detektēt kā otru alēli, atšḳirīgu no mātes alēles. 


\subsection{Rezultāti}

\subsubsection{Vizuāla pārtraukušās grūtniecības materiāla novērtēšana un mātes šūnu kontaminācijas genenētiskā testēšana}

Par koncepcijas paraugu uzskata tādu materiālu, kas nesatur identificējamas aug̣̣a daḷas (piemēram, nabas saite, amnions), bet drīzāk sastāv no horija bārkstin̄ām, membrānveida materiāla (Jarrett et al., 2001) un citiem nenoteiktas izcelsmes audiem. Vizuāli pārbaudot primāro materiālu $(n=86)$, tika iegūti šādi novērojumi: 55 bija labas kvalitātes paraugi, 19 bija nekvalitatīvi horiji ar audu macerācijas pazīmēm un 12 paraugos nevarēja vizualizēt audus ar tipisku horija morfologiju - atzīmēti kā "nav horiona". Trīsdesmit trijos paraugos (70,2\%) no 47 mātes šūnu kontaminācija netika detektēta, viens no tiem bija “nekvalitatīvs horions", bet pārējie bija labas kvalitātes horiji. Astoņi paraugi $(17,0 \%)$ demonstrēja kontaminācijas pazīmes, seši no tiem bija "nekvalitatīvi horioni” un divi neuzrādīja horija klātbūtni. Seši paraugi (12,8\%) uzrādīja tikai mātes genomu, trīs no tiem bija "nekvalitatīvi horioni” un trīs bija bez horiona. Tika aprēkināts, ka izstrādātās sistēmas varbūtība būt neinformatīvai, t.i., uzrādīt nepatiesu rezultātu, ka aug̣̣a paraugs satur tikai mātes genomu, ir 1,9E-08. Tādējādi varēja pieṇemt, ka izstrādātais protokols nodrošina ticamus rezultātus un to var izmantot ar lielu pārliecību.

\subsubsection{Hromosomu analīze ar salīdzinošo genoma hibridizāciju uz mikročipiem}

Kopsumā 34 paraugi uzrādīja normālu sievietes kariotipu un 16 - normālu vīrieša kariotipu (dzimumu attiecība 2,1:1). Pārējie 36 paraugi $(41,9 \%)$ uzrādīja kādu hromosomālu patoloǵiju, 12 no tiem saturēja XX dzimumhromosomas un 
11 saturēja XY dzimumhromosomas (dzimumu attiecība 1:0,9), 13 paraugos tika atklāta dzimumhromosomu patologiija.

\subsubsection{Augsta mātes šūnu kontaminācijas riska pārtraukušās grūtniecības materiāla analīze}

Katrs 46,XX kariotipa rezultāts ir jāuztver piesardzīgi, jo tas var rasties, analizējot mātes šūnas, īpaši neapmierinošas vizuālās kvalitātes paraugos. Kā redzams no 3.1. attēla, jo sliktāka ir analizējamā parauga vizuālā kvalitāte, jo lielāka ir 46,XX paraugu proporcija un jo zemāka ir 46,XY un aneiploīdo paraugu daḷa.

\section{Vizuāli novērtētie paraugi}

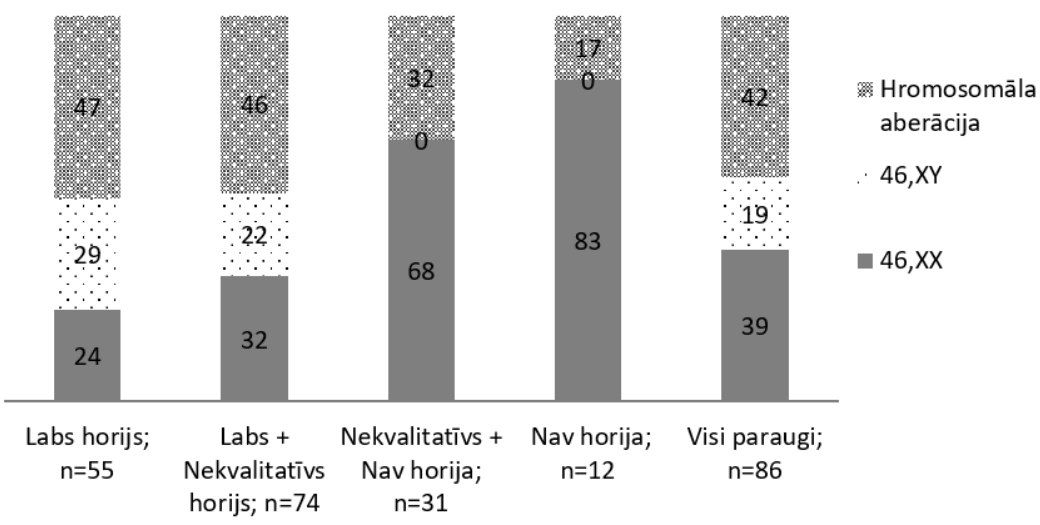

\section{1. attēls. Kariotipa rezultātu sadalījums dažādas vizuālās kvalitātes paraugos}

Šūnu / audu izcelsme ar 46,XY kariotipu vai jebkādu hromosomālu anomāliju ( $\mathrm{n}=28)$ ir neapšaubāma (t.i., aug̣̣a). 3.2. attēls vizuāli atspoguḷo to, ka lielākā daḷa šo gadījumu (82,1\%) koncentrējās paraugos ar labu vizuālo 
kvalitāti bez mātes šūnu kontaminācijas. Tomēr četri gadījumi (14,3\%) tika konstatēti starp zemas kvalitātes paraugiem, trijos no tiem bija atrastas arī kontaminācijas pazīmes. Balstoties uz standarta kritērijiem, kompromitētās vizuālās kvalitātes paraugi tiktu izmesti (Romero et al., 2015), jo dzīvotspējīgu šūnu klātbūtne ir izšķiroša citoǵenētiskajai analīzei, arī parafīna paraugiem pirms DNS ekstrakcijas parasti bija nepieciešams patologa slēdziens par augḷa šūnu klātbūtni. Šeit mēs parādām, kā vienkāršs un ātrs mātes šūnu kontaminācijas novērtēšanas solis var glābt daļu no sliktajiem paraugiem un palielināt korekto diagnožu skaitu.

Tikai mātes genoms (6)

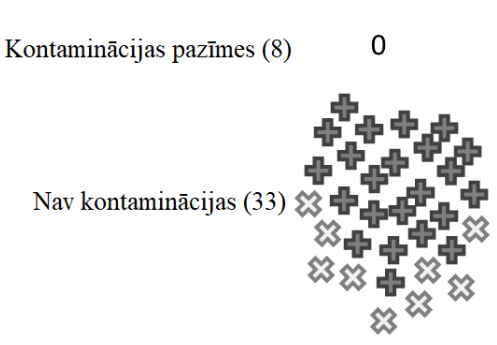

Labas kvalitātes horijs (32)
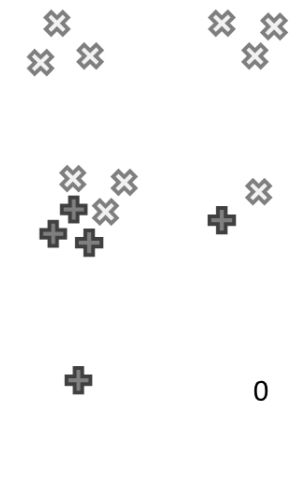

Nekvalitatīvs horijs Nav horija (5)

(10)

\section{2. attēls. Paraugu sadalījums atkarībā no vizuālās kvalitātes} un mātes šūnu kontaminācijas klātbūtnes 


\section{Dzemdes kakla nepietiekamības izraisītu priekšlaicīgu dzemdību genētiskā etioloǵija: sistemātiska gēnu analīze un pacientu nākamās paaudzes sekvencēšanas datu interpretācija}

Publicēts kā:

Ludmila Volozonoka, Dmitrijs Rots, Inga Kempa, Anna Kornete, Dace Rezeberga, Linda Gailite, Anna Miskova, 2020. Genetic landscape of preterm birth due to cervical insufficiency: Comprehensive gene analysis and patient next-generation sequencing data interpretation. PloS one, 15(3), e0230771. doi: 10.1371/journal.pone.0230771.

Personīgais ieguldījums:

Mans person̄̄gais ieguldījums šajā darbā ietver pētījuma dizaina izstrādi, sistemātisku literatūras un gēnu analīzi, nākamās paaudzes sekvencēšanas datu interpretāciju, publikācijas uzrakstī̌sanu. Lūdzu, skatiet visu līdzautoru parakstītus apliecinājumus dotās publikācijas izmantošanai manā promocijas darbā (5. pielikums).

\subsection{Ievads}

Medicīnisks stāvoklis dzemdniecībā, kad dzemdes kakls spontāni sāk atvērties un kḷūst plānāks bez dzemdību pazīmēm un simptomiem, ir dzemdes kakla nepietiekamība. Dzemdes kaklam, kā audi ir bagāti ar kolagēnu, grūtniecības laikā jāpaliek noslēgtam, taču vienlaikus jāveic pakāpeniska fiziologiiskā pārveidošana, lai sagatavotos dzemdībām (Word et al., 2007). Dzemdes kakla nepietiekamības gadījumā tas nespēj uzturēt progresējošas grūtniecības spiedienu. Klīniski nozīmīga izolēta dzemdes kakla nepietiekamība novērojama apmēram 1-2\% no visām grūtniecībām, bet ir saistīta ar 
5-15\% grūtniecības zaudējumiem otrajā trimestrī (Mingione et al., 2003; SW Wang et al., 2016). Rutīnu dzemdes kakla mērīšanu 2011. gadā ieteica Globālā alianse priekšlaicīgu dzemdību un nedzìvi dzimušu bērnu novēršanai (Goldenberg et al., 2012), jo īss dzemdes kakls ir labākais spontāno dzemdību prognozēšanas faktors (Di Renzo, 2015).

Epidemioloǵiskie dati rāda, ka aug̣̣iem / jaundzimušajiem ar ElersaDanlo sindromu, osteogenesis imperfecta un ierobežojošo dermopātiju ir paaugstināts nelabvēlīgu grūtniecības iznākumu risks, tostarp pārtraukušās grūtniecības, priekšlaicīgs augḷūdens pūş̌la plīsuma, kā arī dzemdes kakla nepietiekamības (Anum et al., 2009; Young et al., 2007).

Bez šaubām, mūsu pašreizējā izpratne par cilvēka dzemdes kakla pārveidošanos grūtniecības laikā ir ierobežota (Vink \& Myers, 2018). Tas var būt par iemeslu ar dzemdes kakla nepietiekamību pētīto gēnu nobīdei un pārsteidzoši mazajam informācijas daudzumam, kas pašlaik ir zināms par dzemdes kakla patologiiskas pārveidošanās ǵenētiku grūtniecības laikā.

N̦emot vērā to, ka gēnu varianti, kurus var atklāt ar genoma asociācijas pētījumiem, parasti izskaidro tikai mazu daḷu no kompleksu slimību iedzimstamības (Asimit \& Zeggini, 2010), pastāv hipotēze, ka retie varianti vairākos gēnos, kas iesaistīti priekšlaicīgu dzemdību attīstībā, var kumulatīvi ietekmēt predispozīciju grūtniecības atrisināšanai pirms laika (Bezold et al., 2013; Strauss et al., 2018). Mēs nolēmām pārbaudīt šo hipotēzi, veicot nākamās paaudzes sekvencēšanu pacientēm ar izolētu nesindromisku dzemdes kakla nepietiekamību. Tā kā trūkst zināšanu par dzemdes kakla darbībā iesaistītajiem gēniem, mēs veicām sistemātisku literatūras analīzi, lai atlasītu visus iespējamos gēnus, saistītus ar dzemdes kakla funkciju. N̦emot vērā aprakstìto dzemdes kakla nepietiekamības iedzimstamību, galvenie jautājumi, kuriem mēs pievērsāmies šajā pētījumā, bija šādi: i) vai ir gēni, kas ir primāri saistīti ar dzemdes kakla 
nepietiekamību, un, ja ir, tad kāda ir to loma? un ii) cik daudz izolētas nesindromiskas dzemdes kakla nepietiekamības gadījumu var būt attiecināmi uz ǵenētiskajām variācijām?

\subsection{Materiāli un metodes}

\subsubsection{Dzemdes kakla bioloğijā iesaistīto gēnu identificēšana}

Literatūras meklēšana tika veikta saskaṇā ar PRISMA vadlīnijām (Moher et al., 2009). Iekḷaušanas kritēriji: pētījums publicēts recenzētā žurnālā; pētījums demonstrē oriǵinālus datus; pētījums koncentrējas uz dzemdes kakla nepietiekamības un / vai priekšlaicīgu dzemdību genētiskā cēloṇa atrašanu; pētījums izmanto dzemdes kakla audus funkcionālajai gēnu analīzei, lai pētītu dzemdes kakla nobriešanu, dzemdes kakla nepietiekamību un / vai priekšlaicīgas dzemdības. Tika ieklauti tikai cilvēku pētījumi.

Izslēgšanas kritēriji: pētījums koncentrējas uz spontāno abortu un / vai pirmo grūtniecības trimestri; pētījums koncentrējas uz mikroRNS, lncRNS, brīvi cirkulējošo DNS, ribosomu DNS, dzemdes kakla un maksts mikrobiomu, vēža analīzi; pētījums neanalizē cilvēka datus; pētījums nav pieejams angḷu valodā. Pamatojoties uz datiem, kas iegūti no visiem iekḷautajiem pētījumiem un papildu gēnu meklējumiem, mēs izveidojām trīs dažādus gēnu sarakstus atbilstoši to saistībai ar dzemdes kakla genētiku. 


\subsubsection{Nākamās paaudzes sekvencēšana pacientiem ar dzemdes kakla nepietiekamību}

\section{Pacienti}

Pētījums iekḷāva 21 kaukāziešu tautības sievieti ar nesāpīgu dzemdes kakla atvēršanos pašreizējās grūtniecības laikā un / vai pozitīvu grūtniecības zaudēšanu un / vai priekšlaicīgām dzemdībām anamnēzē dzemdes kakla nepietiekamības dẹḷ un bez kontrakcijām viena aug̣̣a grūtniecīibā (sk. 4.1. tabulu).

4.1. tabula

\section{Pacientu demogrāfiskās un klīniskās īpašības}

\begin{tabular}{|c|l|}
\hline Vecums, gadi & $35 \pm 4,8$ \\
\hline Svars, kg & $73,2 \pm 16,7$ \\
\hline Augums, m & $1,7 \pm 0,05$ \\
\hline KMI, kg / m ${ }^{2}$ & $26 \pm 5,5$ \\
\hline VG & $4,5 \pm 2,5$ \\
\hline CG & $1,0 \pm 1,1$ \\
\hline VG-CG & $3,5 \pm 2,2$ \\
\hline AGP & $0,5 \pm, 0$ \\
\hline VGP + PD & $1,9 \pm 1,7$ \\
\hline DKG, cm & $1,53 \pm 0,5$ \\
\hline
\end{tabular}

* ĶMI - ķermeņa masas indeks; VG - visas grūtniecības; CG - citas grūtniecības, ieskaitot legālo abortu, indicēto medicīnisko abortu; VG-CG visas grūtniecības, atskaitot citas grūtniecības; AGP - agrīna grūtniecības zaudēšana ( $<12$ nedēḷas); VGP + PD - vēlīna grūtniecības zaudēšana (> 12 nedēlas, < 22 nedēḷas) un priekšlaicīgas dzemdības (<37 nedēḷas); DKG - dzemdes kakla garums. 


\section{Nākamās paaudzes sekvencēšana, bioinformātikas analīze un variantu filtrēšana}

Nākamās paaudzes sekvencēšanai tika izmantots Illuminas TruSight One Sequencing Panel Capture reaǵentu komplekts [ASV]. Nolasījumu kartēšanai un variantu sasaukšanai tika izmantota Sentieon's DNAseq (Freed et al., 2017; Kendig et al., 2019) FASTQ uz VCF analīze, kas implementēta DNAnexus mākoņserverī [ASV]. Pirmais variantu filtrs atlasīja nesinonīmus eksonu variantus un splaisa-saita variantus $( \pm 10 \mathrm{nt})$ kanoniskajā (garākajā) transkriptā. Tika iekḷauti varianti ar alēles biežumu < 1\% datubāzēs "1000 Genomes", "ExAC" un "gnomAD”. Otrais variantu filtrs atlasīja variantus, pārklātus ar vismaz 10 nolasījumiem, ar varianta alēles biežumu vismaz 25\%, un izslēdza zināmus variantus, marḳētus kā "neitrāls" (angl. benign) un "visdrīzāk neitrāls" (angl. likely benign) klīniskajās datubāzēs.

\section{Variantu klasifikācija, prioritizācija un gēnu bagātināšanas analīze}

Ģenētiskie varianti tika prioritizēti, izmantojot trīs sistemātiskajā gēnu analīzē izveidotos gēnu sarakstus. Varianti, kas atrasti gēnos no pirmā un otrā saraksta, prioritizēti, tāpēc tika rūp̄̄gi apakatīti, lai identificētu tos variantus, kas, visticamāk, veicina pacientu fenotipa attīstību. Katra šī saraksta varianta patogenitāti vērtēja trīs neatkarīgi zinātnieki saskaņā ar Amerikas Medicīniskās ǵenētikas koledžas vadlīnijām (Richards et al., 2015). Lai iegūtu objektīvu informāciju par ceḷu bagātināšanu gēnos, kuriem mūsu kohortā ir reti varianti ar in silico paredzētu ietekmi uz gēna funkciju, mēs anotējām gēnus, izmantojot ConsensusPathDB datubāzi (Kamburov et al., 2013). 


\subsection{Rezultāti}

\subsubsection{Gēnu analīze: gēni, kas saistīti ar dzemdes kakla nepietiekamību, galvenokārt ir sindromiski}

Kopumā tikai 12 gēni tika primāri saistīti ar dzemdes kakla nepietiekamību (sk. 4.2. tabulu), no tiem seši bija sindromiski, t.i., COL1Al un COL3A1 izraisa Elersa-Danlo sindromu (EDS); FBN1 izraisa Marfāna sindromu; ZMPSTE24 un LMNA izraisa ierobežojošo dermopātiju; MATR3 izraisa miopātiju. COL3A1 bija vienīgais gēns ar zināmu gēna-fenotipa saistību, kā parādīts cilvēka fenotipa ontolog̣ijas apzīmējumā "Dzemdes kakla nepietiekamība" (HP:0030009), kā arī "Priekšlaicīgas dzemdības dēḷ dzemdes kakla nepietiekamības vai membrānas trausluma" (HP:0005267), "Dzemdes plīsums" (HP:0100718) un "Dzemdes prolapss" (HP:0000139), un ir zināms, ka tas izraisa asinsvadu tipa EDS (OMIM:130050).

4.2. tabula

Gēni, kas primāri saistīti ar dzemdes kakla nepietiekamību (pirmais gēnu saraksts)

\begin{tabular}{|c|c|}
\hline Gēns & Asociācijas no literatūras un papildu meklējumiem \\
\hline COL1A1 & $\begin{array}{l}\text { Elersa-Danlo sindroms; dzemdes kakla nepietiekamība; } \\
\text { priekšlaicīgas dzemdības; priekšlaicīgs aug̣̦ūdens pūșla plīsums; } \\
\text { dzemdes kakla fizioloğiskā sagatavošanās; fizioloğiska } \\
\text { grūtniecība. }\end{array}$ \\
\hline COL3A1 & $\begin{array}{l}\text { Elersa-Danlo sindroms; dzemdes kakla nepietiekamība } \\
\text { HP:0030009 / priekšlaicīgas dzemdības dzemdes kakla } \\
\text { nepietiekamības vai membrānas trausluma dēḷ HP:0005267 / } \\
\text { dzemdes plīsums HP:0100718 / dzemdes prolapss HP:0000139; } \\
\text { priekšlaicīgs augḷūens pūšḷa plīsums; priekšlaicīgas dzemdības; } \\
\text { dzemdes kakla fizioloğiskā sagatavošanās; fizioloğiska } \\
\text { grūtniecība; priekšlaicīgas dzemdes kontrakcijas. }\end{array}$ \\
\hline FBN1 & $\begin{array}{l}\text { Marfāna sindroms; dzemdes kakla nepietiekamība; priekšlaicīgs } \\
\text { aug̣̦ūdens pūšla plīsums; priekšlaicīgas dzemdes kontrakcijas. }\end{array}$ \\
\hline
\end{tabular}


4.2. tabulas turpinājums

\begin{tabular}{|c|c|}
\hline Gēns & Asociācijas no literatūras un papildu meklējumiem \\
\hline HIF $1 A$ & $\begin{array}{l}\text { Dzemdes kakla nepietiekamība; dzemdes kakla fizioloğiskā } \\
\text { sagatavošanās; fizioloğiska grūtniecība. }\end{array}$ \\
\hline IL10 & Dzemdes kakla nepietiekamība; priekšlaicīgas dzemdības. \\
\hline$I L 1 B$ & $\begin{array}{l}\text { Dzemdes kakla nepietiekamība; priekšlaicīgas dzemdības; } \\
\text { dzemdes kakla fizioloğiskā sagatavošanās; fizioloğiska } \\
\text { grūtniecība. }\end{array}$ \\
\hline IL6 & $\begin{array}{l}\text { Dzemdes kakla nepietiekamība; priekšlaicīgas dzemdības; } \\
\text { dzemdes kakla fizioloğiskā sagatavošanās; fizioloğiska } \\
\text { grūtniecība. }\end{array}$ \\
\hline$L M N A$ & $\begin{array}{l}\text { Ierobežojoša dermatopātija; priekšlaicīgas dzemdības dzemdes } \\
\text { kakla nepietiekamības vai membrānas trausluma dēl } \\
\text { HP:0005267; priekšlaicīgs membrānu plīsums HP:0001788. }\end{array}$ \\
\hline MATR3 & Miopātija MATR3 mutāciju dēḷ; dzemdes kakla nepietiekamība. \\
\hline$M B L 2$ & Dzemdes kakla nepietiekamība; priekšlaicīgas dzemdības. \\
\hline$T G F B 1$ & $\begin{array}{l}\text { Dzemdes kakla nepietiekamība; priekšlaicīgas dzemdības; } \\
\text { dzemdes kakla fizioloğiskā sagatavošanās; fiziologiska } \\
\text { grūtniecība. }\end{array}$ \\
\hline ZMPSTE24 & $\begin{array}{l}\text { Ierobežojoša dermatopātija; priekšlaicīgas dzemdības dzemdes } \\
\text { kakla nepietiekamības vai membrānas trausluma dēḷ } \\
\text { HP:0005267; priekšlaicīgs augḷūdens pūșla plīsums; } \\
\text { priekšlaicīgas dzemdības. }\end{array}$ \\
\hline
\end{tabular}

\subsubsection{Pacientu nākamās paaudzes sekvencēšanas datu analīze}

Divdesmit heterozigotiski varianti, kas atrasti 14 no mūsu pacientiem (67\%) no pirmā un otrā gēnu sarakstiem, tika paḳ̣auti tuvākai analīzei, jo, pamatojoties uz zināšanām, tika uzskatīts, ka tie, visticamāk, veicina pacientu fenotipa attīstību (sk. 4.3. tabulu). Tika atrasti 14 varianti desmit gēnos, kas izraisa EDS, osteogenesis imperfecta vai Betlema miopātiju.

Galu galā, pamatojoties uz visaptverošu variantu patogenitātes, tostarp zināmu gēna-slimības / gēna-fenotipa asociāciju, gēnu ekspresijas dzemdes kaklā un konkrētu gēnu slimību mehānismiem u.tml. novērtēšanu, mēs piešḳīām variantam varbūtību pacienta fenotipa attīstības ieguldījumā (sk. 4.3. tabulas 
pēdējo kolonnu). Varianta ieguldījums fenotipa attīstībā tika klasificēts kā maz ticams ieguldījums $(\mathrm{n}=7)$, ja tas tika klasificēts kā neitrāls / visdrīzāk neitrāls saskaņā ar manuālo variantu patogenitātes novērtēšanu, neekspresējās vai vāji ekspresējās dzemdes kaklā vai arī tā zināmās gēna-slimības / gēna-fenotipa asociācijas neatbilda interesējošajam fenotipam. Variantam ir nepieciešama papildu izmeklēšana $(\mathrm{n}=13)$, ja tas, pamatojoties uz novērtētajiem kritērijiem, parādīja teorētisku potenciālu palielināt uzņēmību pret interesējošā fenotipa attīstību, taču ir nepieciešams vairāk datu, lai atzītu variantu kā nepārprotami iesaistītu dzemdes kakla nepietiekamības attīstībā.

\subsubsection{Molekulāro gēnu ceḷu bagātināšanas analīze}

Lai noteiktu, vai gēniem ar retiem variantiem mūsu pacientu kohortā ir fenotipam atbilstoša molekulāro ceḷu bagātināšanās, mēs anotējām visus gēnus ( $n=694$ ), izmantojot ConsensusPathDB mijiedarbības datubāzi (Kamburov et al., 2013), izmantojot TruSight gēnu sarakstu kā fonu $(n=4810)$. Analīze atklāja izteiktu pārstāvniecību ceḷos, kas saistīti ar audu mehānisko un biomehānisko izturību (kolagēni un proteoglikāni, integrīni). Tika novērota bagātināšana ne tikai ar ekstracelulāro matriksu saistītajos ceḷos, bet arī šūnas saziṇā ar ekstracelulāro matriksu (piemēram, hemidesmosomas, fokālā adhēzija) un bazālās membrānas komponentos (laminīni). Turklāt vairāki šeit identificētie ceḷi sakrīt ar tiem, kas ir bagātināti gēnos, kuri pētīi saistībā ar dzemdes kakla genētiku, kā parādīts mūsu literatūras analīzē. 


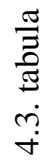

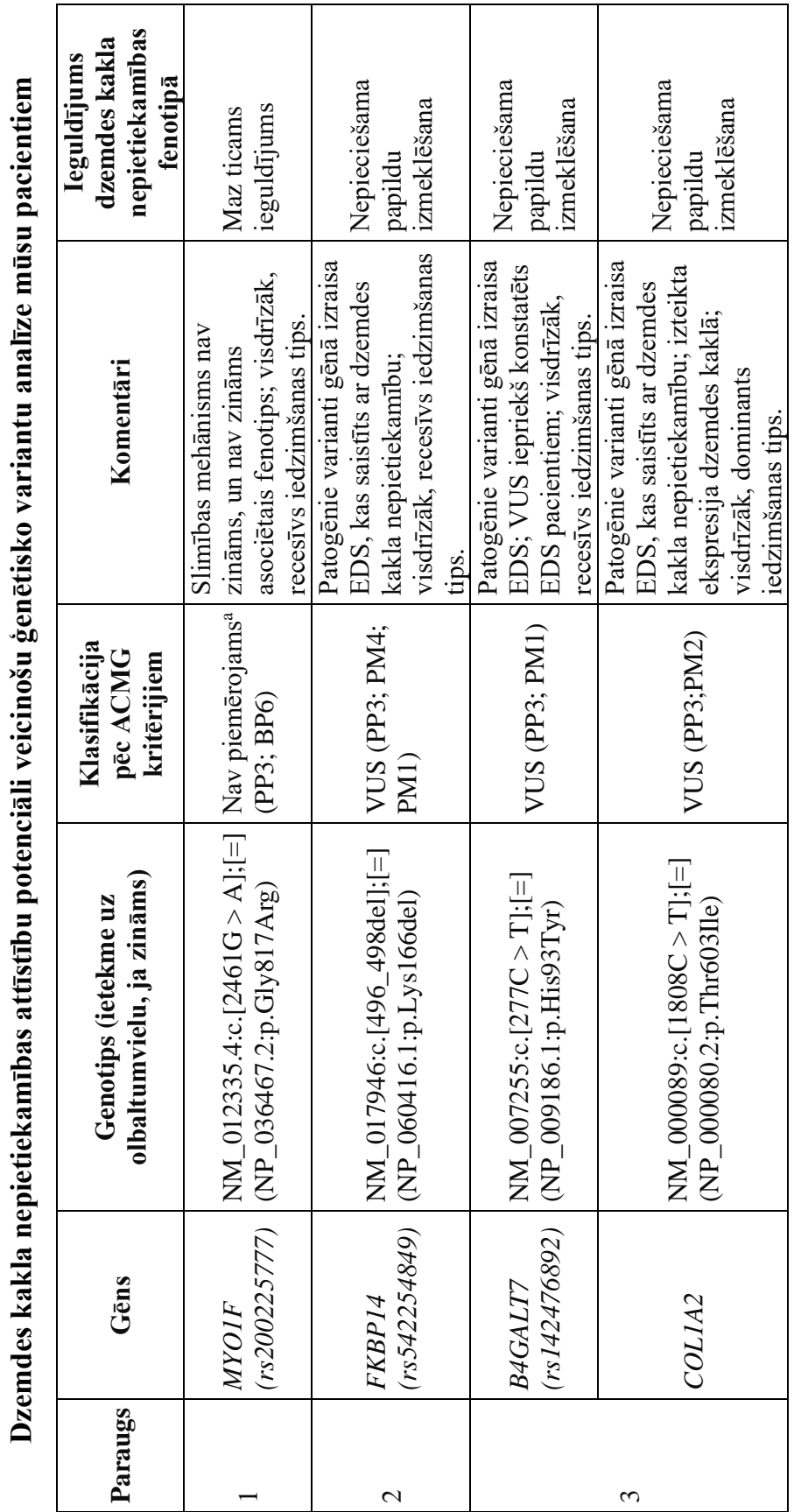


童

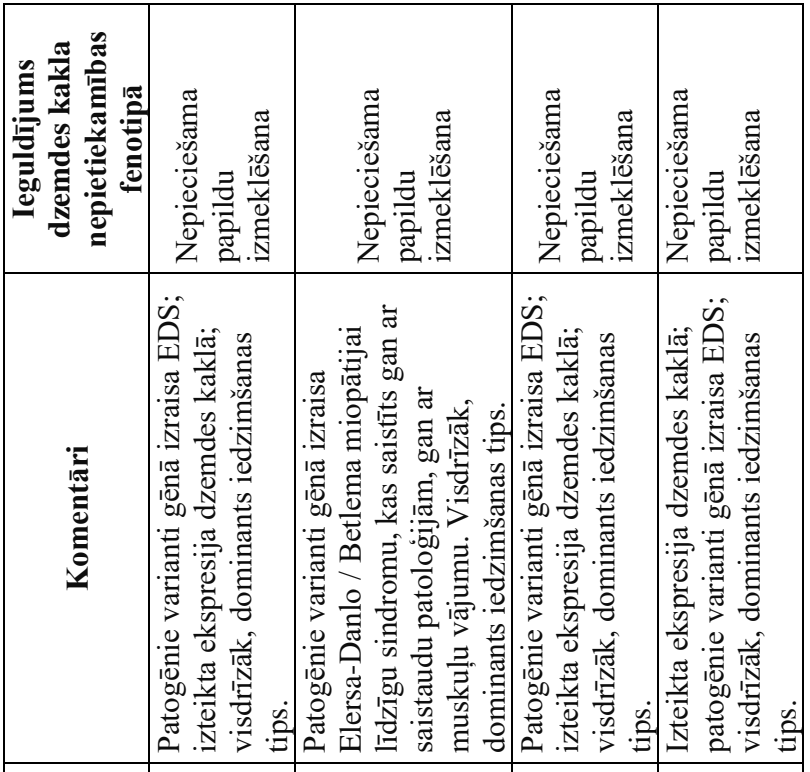

\begin{tabular}{|c|c|c|c|c|}
\hline 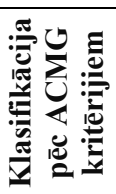 & 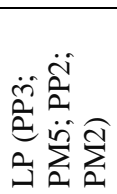 & 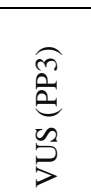 & 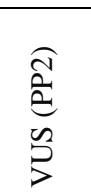 & 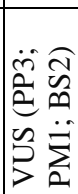 \\
\hline 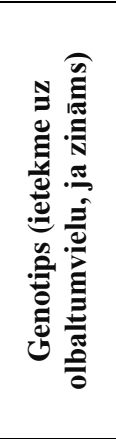 & 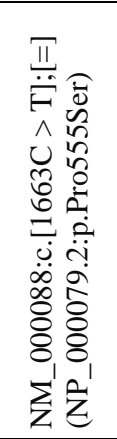 & 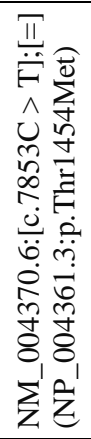 & 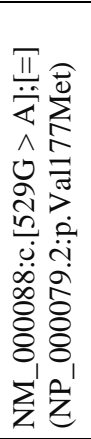 & 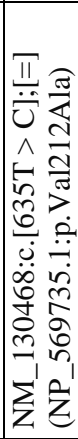 \\
\hline 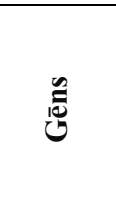 & 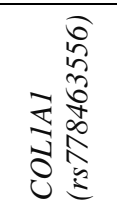 & 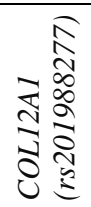 & 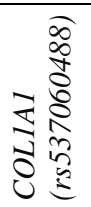 & 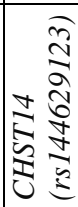 \\
\hline 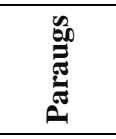 & & & & \\
\hline
\end{tabular}


志

\begin{tabular}{|c|c|c|c|c|}
\hline 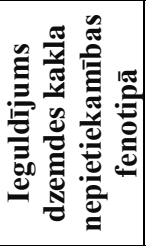 & 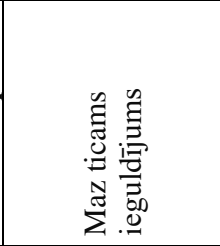 & 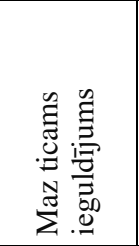 & 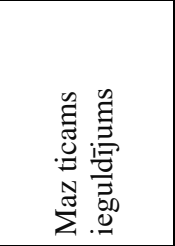 & 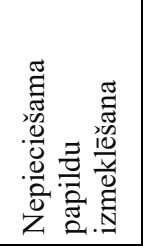 \\
\hline 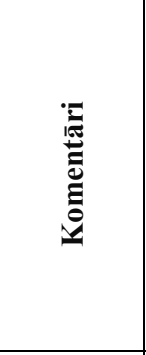 & 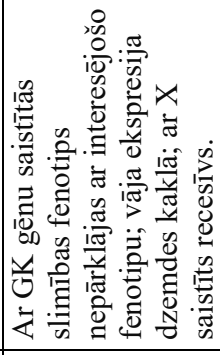 & 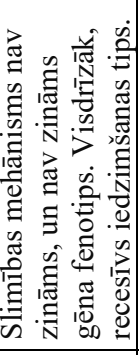 & 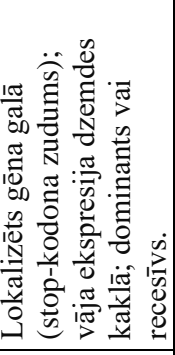 & 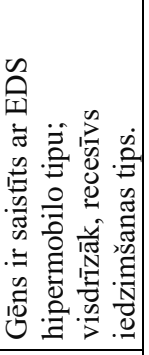 \\
\hline 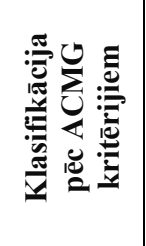 & 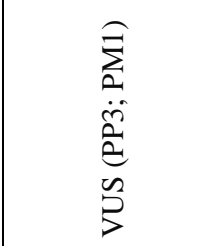 & 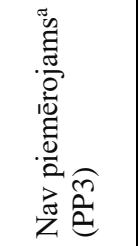 & 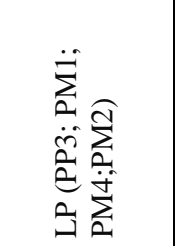 & 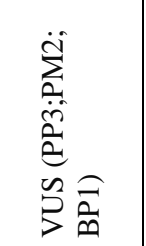 \\
\hline 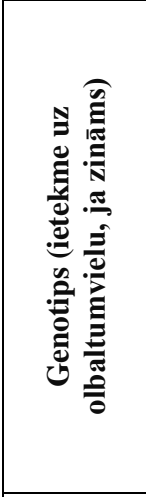 & 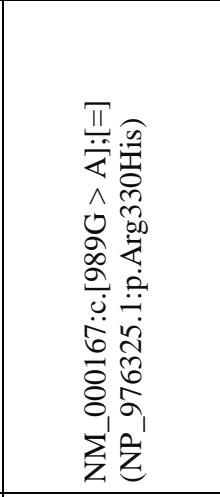 & 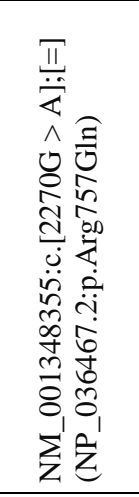 & 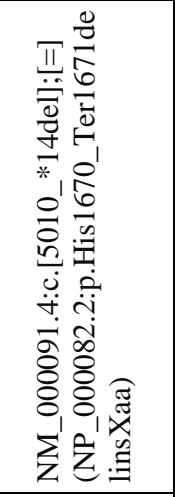 & 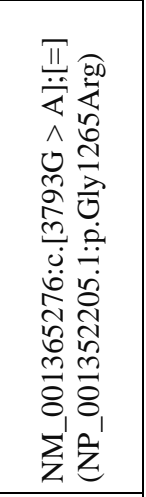 \\
\hline 芯 & 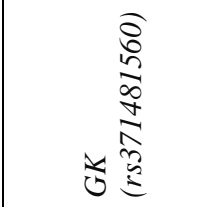 & 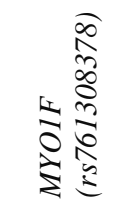 & 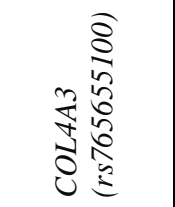 & $\sum_{k}^{\infty}$ \\
\hline 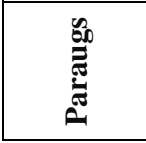 & 6 & & & $\infty$ \\
\hline
\end{tabular}


童

\begin{tabular}{|c|c|c|c|c|}
\hline 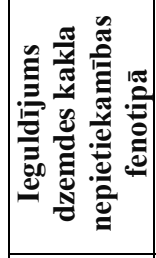 & 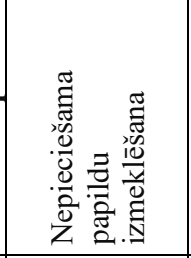 & 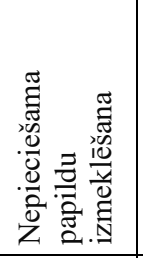 & 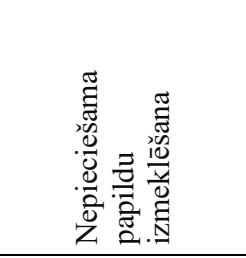 & 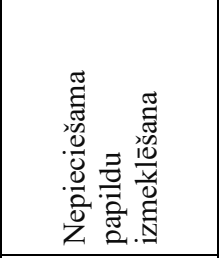 \\
\hline 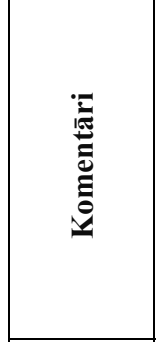 & 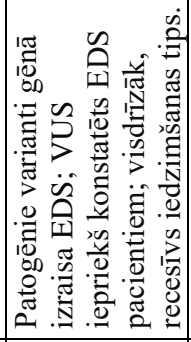 & 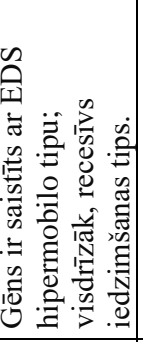 & 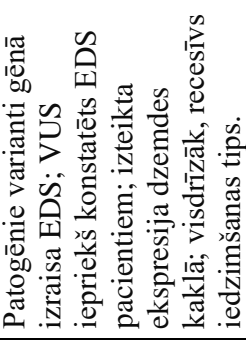 & 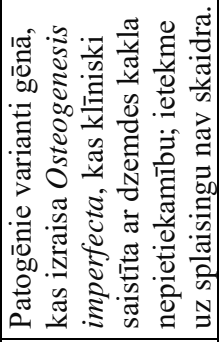 \\
\hline 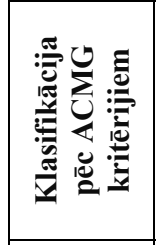 & 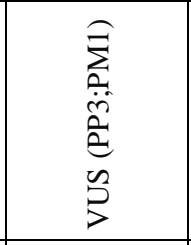 & 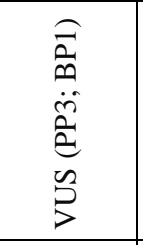 & 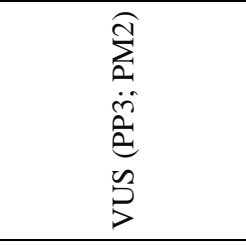 & $\stackrel{2}{>}$ \\
\hline 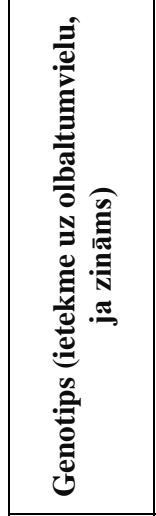 & 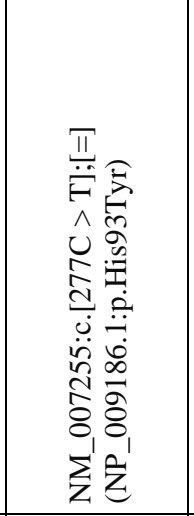 & 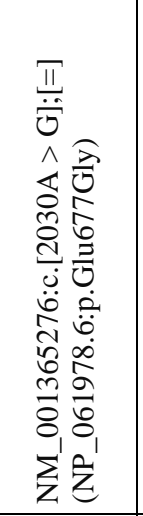 & 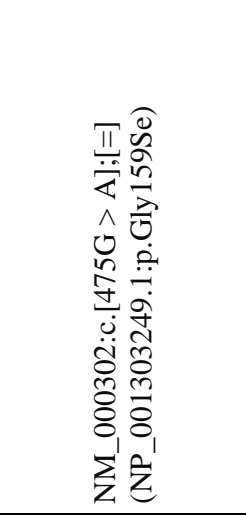 & 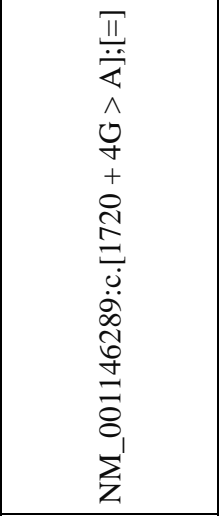 \\
\hline טِّ & 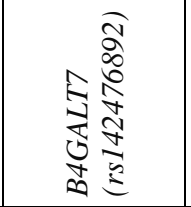 & 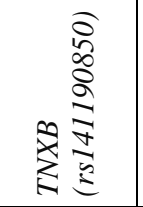 & 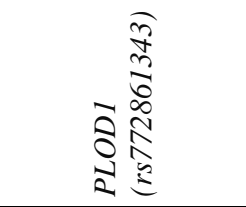 & 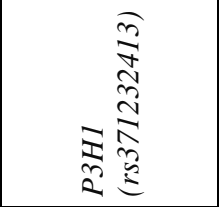 \\
\hline 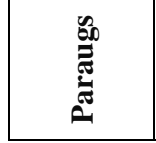 & & & 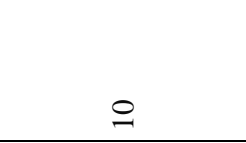 & - \\
\hline
\end{tabular}


弯

\begin{tabular}{|c|c|c|c|}
\hline 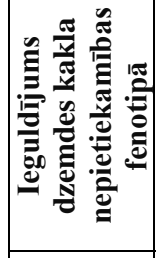 & 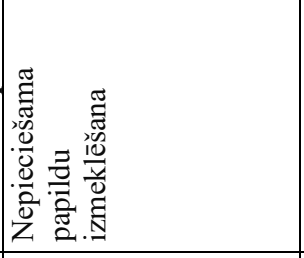 & 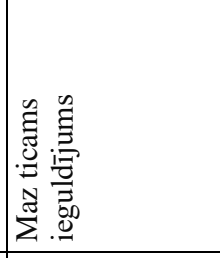 & 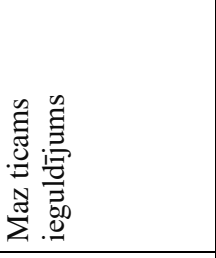 \\
\hline 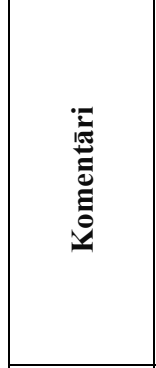 & 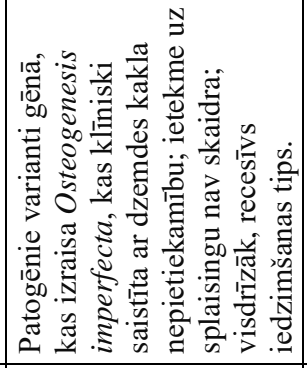 & 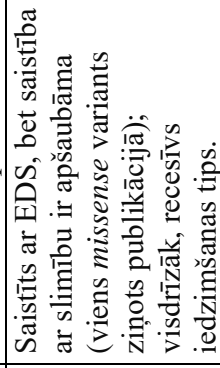 & 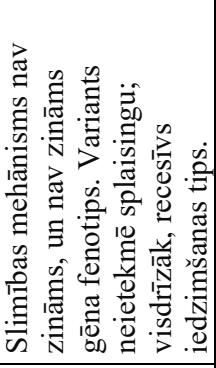 \\
\hline 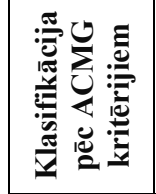 & $\stackrel{\tilde{s}}{\rho}$ & $\begin{array}{l}\ddot{\tilde{n}} \\
\tilde{n} \\
\stackrel{\tilde{n}}{\tilde{n}}\end{array}$ & 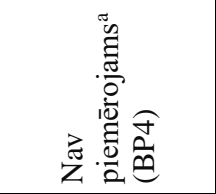 \\
\hline 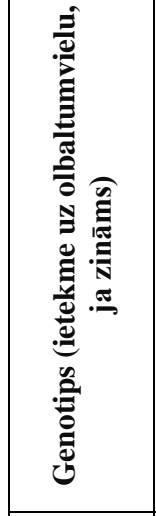 & 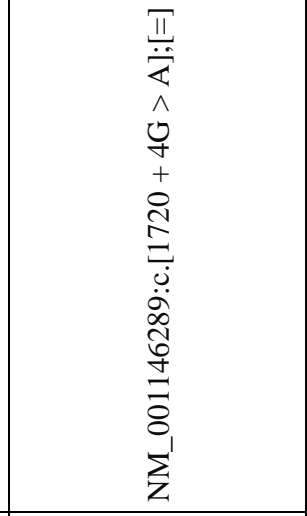 & 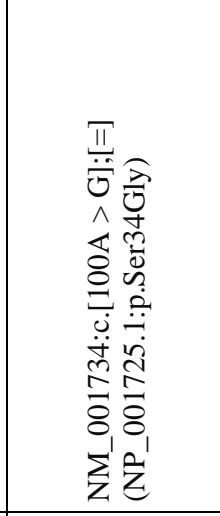 & 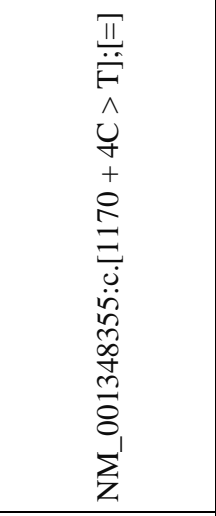 \\
\hline 芯 & 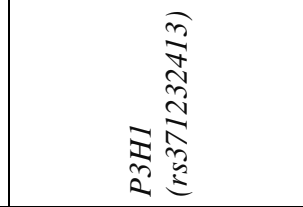 & 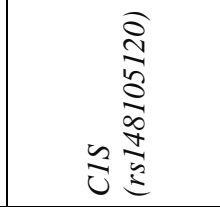 & 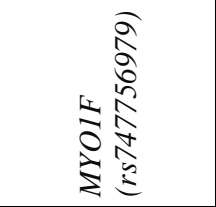 \\
\hline 哭 & $\simeq$ & & \\
\hline
\end{tabular}




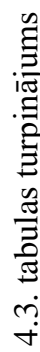

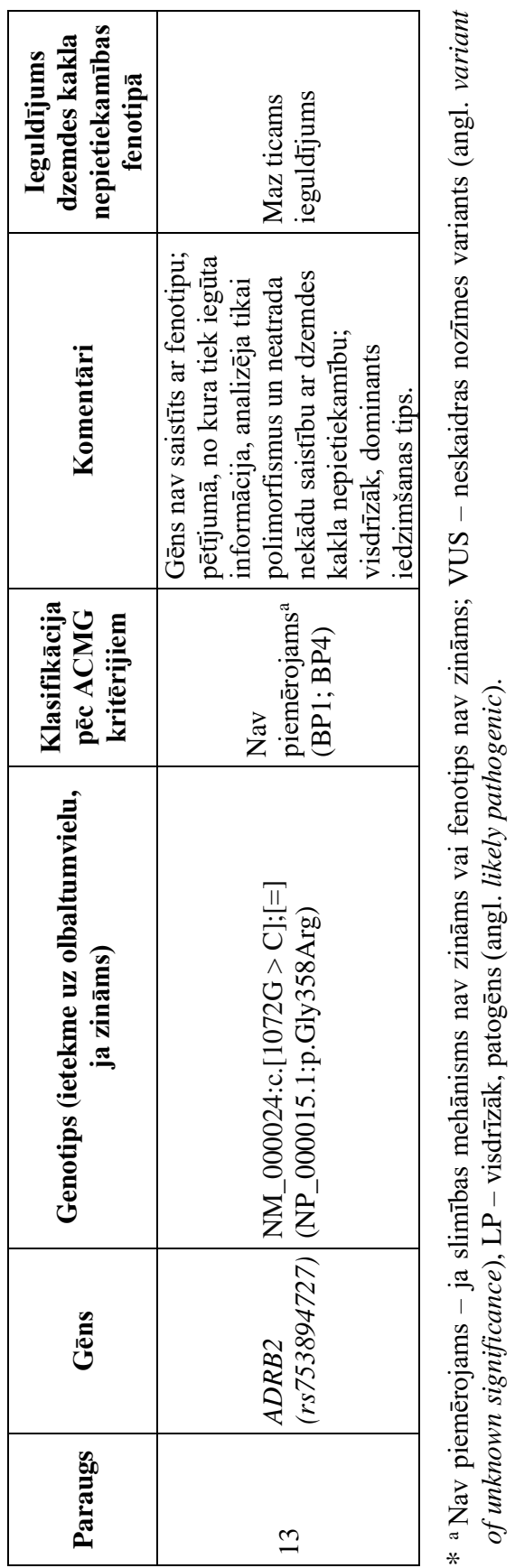




\section{Kopīgā diskusija}

\subsection{Labākās tehnologijijas izvēle pirmsimplantācijas genētiskajai testēšanai}

Šīs disertācijas pirmajā praktiskajā darbā, kas aprakstīts 2. nodaḷā, tika apskatīta embriju pirmsimplantācijas analīze pāriem ar paaugstinātu risku bērna piedzimšanai ar monogēnu patologiju. Papildus uzdevumam uzturēt visaugstākos PG̣T drošības standartus mēs izvirzìjām mērḳi sasniegt vēlamo grūtniecību katram no pāriem. Tā kā tirgū nebija pieejamas nevienas PG̣T sistēmas, mēs visu testēšanas protokolu izstrādājām no nulles, jau pašā sākumā saskaroties ar izaicinājumu izvēlēties pareizos rīkus, t.i., reaǵentus un metodes. Tāpēc mēs nolēmām i) salīdzināt divas populārākās pilna genoma amplifikācijas metodes un ii) detalizēti dalīties savā praktiskajā pieredzē ar tiem, kas saskaras ar to pašu izaicinājumu. Rezultātā mēs bijām apmierināti ar savu sniegumu, jo astoṇiem pāriem no deviṇiem piedzima veseli bērni, kas tika apstiprināts arī postnatāli. Tikai vienā gadījumā (MTMl) neviena olšūna netika veiksmīgi apaugḷota, limitējot pāra iespējas ieņemt veselu bērnu. Trīs embriju pārnešanas rezultējās neveiksmīgā implantācijā, padarot kopējo dzimstību uz embrija pārnesi par 72,7\%, kas joprojām pārsniedz vidējo ziṇoto literatūrā (Butler et al., 2019; Theobald et al., 2020). Nelielais aplūkoto gadījumu skaits apgrūtina iespējas prognozēt augsta dzimstības līmeņa tendenci ilgtermiņā, taču mēs to saistām ar visu pārnesto embriju galvenā neizdevušās embrija implantācijas faktora izslēgšanu (aneuploīdu embriju daudzums bija 37,5\%). Tomēr tiek uzsvērts, lai noteiktu PG̣T-A klīnisko efektu PG̣T-M cikliem, ir nepieciešami randomizēti kontrolēti pētījumi (Toft et al., 2020). 
No 73 apstrādātiem embrijiem 39 tika amplificēti, izmantojot MDA, bet 34 - SurePlex amplifikācijas sistēmu, lai novērtētu divu pilna genoma amplifikācijas metožu veikumu četrās dažādās tehnologijāàs un izvēlētos vispiemērotāko. Mūsu rezultāti vēlreiz apstiprina zināmu faktu, ka MDA amplifikācija ir piemērota viena vai dažu lokusu analīzei, kā mēs parādījām, neatkarīgi no izmantotās tehnologiijas, savukārt SurePlex pilnībā atbilst tādu genomisko tehnoloǵiju lietošanas prasībām kā salīdzinošā genoma hibridizācija uz mikročipiem vai nākamās paaudzes sekvencēšana. Kaut gan tikai divās ǵimenēs mēs varējām vienlaikus izmantot abas pilna genoma amplifikācijas metodes, mēs uzskatām šādu pieeju par praktisku un pragmatisku. Tas ḷauj iegūt daudzpusīgāku PG̣T pieredzi, jo hromosomu analīze uz mikročipiem, izmantojot MDA, ir iespējama tikai aptuveni divās trešdaḷās gadījumu un tikai pilnām hromosomām, bet ne daliējām kopiju skaita variācijām. Savstarpējā metožu validācija deva mums iespēju secināt, ka abus amplifikatorus var izmantot jebkurai turpmākai embriju analīzes tehnologijai ar pietiekami labu jutību, ja PG̣T-M labās prakses vadlīnijas tiek ievērotas (Hellani et al., 2004; Piyamongkol et al., 2003). Galu galā mūsu centieni l̦auj pielāgot izstrādāto testēšanas sistēmu praktiski jebkurai viena gēna patologijai.

\subsection{Pārtraukušās grūtniecības materiāla ġenētiskās testēšanas uzticamības uzlabošana}

Nākamais praktiskais darbs, kas aprakstīts 3. nodaḷā - koncepcijas produktu ǵenētiskā testēšana augḷa hromosomālo patoloǵiju izslēgšanai -, tika iniciēts klīniskas nepieciešamības rezultātā. Neskatoties uz pretrunīgi vērtēto koncepcijas produktu ǵenētiskās testēšanas statusu (Carp, 2007), pastāv scenāriji, kuros zināšanas par aug̣̣a kariotipu palīdz klīniskai pacienta vadīšanai (Lathi et al., 2012), jo jebkura prognoze ir empīriska, ja bojāgājušā augḷa 
kariotips ir nezināms. Tomēr pastāvošā mātes šūnu kontaminācijas problēma var apdraudēt visu nodomu nodrošināt labāko aprūpi šiem pacientiem.

Tā kā salīdzinošā genoma hibridizācija uz mikročipiem tika parādīta kā avārijas kariotipēšanas metodika pārtraukušās grūtniecības materiāla analīzē (Kudesia et al., 2014), mēs to izvēlējāmies kā vispiemērotāko instrumentu klīniskai lietošanai. Tomēr drīz pēc ieviešanas mēs saskārāmies ar palielinātu šķietami normālas sievietes kariotipa skaitu testēšanas pārskatos. Šādi koncepcijas produktu testēšana parāda, kā mūsdienīgu tehnologiju lietojums var sagādāt vilšanos, ja to izmanto, neizprotot konkrētās metodikas īpatnības un / vai konkrētā bioloǵiskā materiāla specifiku. Tas stimulēja mūs izstrādāt vienkāršu protokolu, kas varētu atpazīt mātes šūnu kontaminācijas klātbūtni ikvienā paraugā.

Darba rezultātā tika izstrādāts mātes šūnu kontaminācijas noteikšanas protokols, kurš ir zemu resursu papildinājums jebkuram koncepcijas produktu testēšanas protokolam laboratorijā un kuram ir būtisks potenciāls uzlabot klīnisko vadību pacientiem ar agrīnu grūtniecības zaudēšanu. Mēs piedāvājām jaunu polimorfu īsu tandēma atkārtojumu marķieru komplektu, kas būtu tikpat uzticams kā komerciāli pieejamie komplekti (piemēram, Identifiler no Thermofisher), un tas ir arī lēts risinājums, kas dažās valstīs var būt svarīgs apsvērums. Mūsu pieeja izmantot salīdzinošo genoma hibridizāciju uz mikročipiem apvienojumā ar mātes šūnu kontaminācijas noteikšanu ir alternatīva starp polimorfismu mikročipiem (angl. SNParrays), kas spēj konstitucionāli noteikt mātes šūnu kontamināciju (Lathi et al., 2014), taču to izmantošana ir dārga un darbietilpīga, un citoǵenētisko testēšanu, kas ir zelta standarts koncepcijas produktu analīzē, taču atstāj ievērojamu daḷu paraugu bez rezultāta zaudētas šūnu dz̄ivotspējas dēḷ. Mūsu praktiskie ieteikumi par mātes šūnu kontaminācijas samazināšanu būs noderīgi tiem, kas tikai ievieš koncepcijas produktu g̊enētisko testēšanu. 


\subsection{Dzemdes kakla nepietiekamības genenētiskās etiologijijas atšifrěšana}

Priekšlaicīgas dzemdības tiek uzskatītas par multifaktoriālu jeb kompleksu saslimšanu. No g̊enētiskās epidemiolog̣ijas ir zināms, ka būtiska šādu slimību etioloǵijas dạ̦a slēpjas kompleksā ǵenētikā (Polychronakos, 2008). Multifaktoriālu slimību gēnu identificēšana lielā mērā tika meklēta, izmantojot populāciju pētījumu metodes, piemēram, genoma asociāciju pētījumus (angl. genome wide association studies), galvenokārt to objektīvā un no hipotēzes brīva rakstura dēḷ (Agler \& Divaris, 2020). Diemžēl šādai pieejai nav izdevies identificēt biežas alēles kā ticamus priekšlaicīgu dzemdību marḳierus.

Stāvoklis, kas klīniski asociēts ar priekšlaicīgām dzemdībām, ir dzemdes kakla nepietiekamība. Mēs mēǵinājām atklāt tā ǵenētisko etioloǵiju, lietojot nākamās paaudzes sekvencēšanu 21 klīniski labi raksturotai pacientei ar dzemdes kakla nepietiekamību. Būtiski atzīmēt, ka š̄i pētījuma tēma radās no klīniskas nepieciešamības, jo iespējas laikus prognozēt un novērst šā stāvokḷa sekas pašlaik ir ḷoti ierobežotas tā neskaidrā rakstura dēḷ (Artymuk et al., 2019).

Tā kā ar dzemdes kakla darbību saistîto zināmo gēnu skaits mūsu pētījuma sākumā bija saskaitāms uz vienas rokas pirkstiem, nopietni limitējot nākamās paaudzes sekvencēšanas datu analīzes iespējas mūsu pacientiem, mēs apbruṇojāmies ar a priori zināšanām, veicot visaptverošu un sistemātisku gēnu analīzi. Kopumā identificējām 12 gēnus, kas primāri saistīti ar dzemdes kakla nepietiekamību, no kuriem seši (COL1A1, COL3A1, FBN1, LMNA, MATR3, ZMPSTE24) izraisa kolagenopātiju sindromus, savukārt MBL2 deficīts ir saistīts ar uzṇēmību pret autoimūnām un infekcijas slimībām, IL6, IL1B, IL10 - visi ir iekaisuma procesa mediatori, TGFB1 regulē šūnu proliferāciju un augšanu un HIF 1A ir transkripcijas faktors. Tālāk mēs identificējām 91 gēnu, kas potenciāli ir saistīts ar dzemdes kakla nepietiekamību (otrais gēnu saraksts). Abi gēnu saraksti tika izmantoti sekvencēšanas datu analīzei. Pēc rūpīgas identificēto 
variantu analīzes mēs izdalījām 13 gēnu variantus ar in silico paredzētu ietekmi uz gēna funkciju 10 pacientiem. Būdami uzmanīgi ar variantu interpretāciju, mēs tos nosaucām par "variantiem, kas uzrāda teorētisku potenciālu palielināt uzṇēmību dzemdes kakla nepietiekamības attīstībai, kam nepieciešama turpmāka izpēte". Būtiski, ka 11 varianti tika atrasti gēnos, kas saistīti ar EDS attīstību, un divi - gēnos, kas izraisa osteogenesis imperfecta.

Lai arī kolagēna loma jau sen ir saistīta ar dzemdes kakla nepietiekamības attīstību, tiešo pierādījumu no klīniskajiem pētījumiem trūka. Mēs bijām pirmie, kas mēgināja pêtīt retos variantus un parādīja to lomu šī fenotipa attīstībā, jo iepriekš tika aprakstītas tikai asociācijas ar kolagēna gēnu polimorfismiem. Svarīgi, ka šāda retu variantu ietekme, ko nevar atklāt, veicot genoma asociācijas pētījumus, tika prognozēta jau sen (Levy et al., 2007; Polychronakos, 2008).

Pēc mūsu manuskripta publicēšanas nāca klajā vēl viens jauns pētījums, kura mērḳis bija identificēt molekulāros mehānismus, caur kuriem dzemdes kakla atvēršanās tiek realizēta progesterona un interleikīna IL-1 $\beta$ ietekmē (Kniss \& Summerfield, 2020), un kura rezultāti netieši atbalstīja arī mūsu atradnes. Pierādījumi par progesterona terapeitisko lietderību priekšlaicīgas dzemdes kakla nobriešanas un priekšlaicīgu dzemdību novēršanā sievietēm riska grupā ir labi aprakstīti (Conde-Agudelo \& Romero, 2016). Progesterona receptoru signalizācija ir pamatā daudziem fizioloǵiskajiem procesiem, kas vērsti pret dzemdes kakla pirmstermiņa paplašināšanos (Word et al., 2007). Tomēr joprojām pastāv neatbildēti jautājumi par progesterona darbības molekulārajiem un genētiskajiem mehānismiem. Pētījuma autori izmantoja cilvēka dzemdes kakla stromas fibroblastu primārās kultūras modeli, tie tika stimulēti ar progesteronu, interleikīnu-1 $\beta$ vai abu vielu kombināciju. Rezultāti parādīja, ka interleikīns-1 $\beta$ inducēja ekstracelulārā matriksa proteīnus, to degradējošo enzīmu un glikozaminoglikānu biosintēzē iesaistīto enzīmu diferenciālu ekspresiju. Konkrēti tika parādīta COL3A1 [HGNC:2201] iesaistīšanās, kas ir 
vienīgais gēns ar reg̣istrētu saistību ar dzemdes kakla nepietiekamību, kā arī ELN [HGNC:3327], COL4A1 [HGNC:2202], HAS2 [HGNC:4819] - visi gēni ir iekḷauti mūsu gēnu sarakstos - un B4GALT1 [HGNC:924], CHST11 [HGNC:17422], EXT1 [HGNC:3512], FUT8 [HGNC:4019] un HS3ST3B1 [HGNC:5198] - visi mazākā vai lielākā mērā ir iesaistīti ārpusšūnu matricas darbībā, audu mehāniskajā un biomehāniskajā izturībā (Kniss \& Summerfield, 2020). Šie atklājumi atkārto mūsu molekulāro ceḷu bagātināšanas analīzes secinājumus par kolagēnu saistīto ceḷu nozīmi dzemdes kakla pārveidošanā, kā arī sniedz ieskatu šo notikumu kontrolē ar progesterona starpniecību (Kniss \& Summerfield, 2020).

Vienlaikus ar mūsu manuskriptu iznāca vēl viens interesants Ben-Zvi un kolēǵu pētījums par dzemdes kakla nepietiekamības saistību ar iegurņa orgānu prolapsu un urīna nesaturēšanu (Ben-Zvi et al., 2020). Viņu analīze parādīja, ka sievietēm ar dzemdes kakla nepietiekamību anamnēzē bija lielāks iegurṇa orgānu prolapsu un urīna nesaturēšanas gadījumu skaits (izredžu koeficients 12,8), demonstrējot, ka abiem stāvokḷiem ir līdzīgs patofiziologiskais mehānisms (BenZvi et al., 2020). Patiešām ir pierādījumi, ka iegurņa orgānu un to atbalstošo audu integritāti galvenokārt uztur fibrilārās ārpusšūnu matricas sastāvdaḷas (Carley \& Schaffer, 2000; X. Liu et al., 2006).

Tāpat kā novājināti saistaudi rezultējas dzemdes kakla nepietiekamībā, tie nevar pienācīgi atbalstīt iegurņa pamatnē balstošos orgānus, rezultējoties iegurņa orgānu prolapsā un urīna nesaturēšanā (Ben-Zvi et al., 2020). Tā kā mēs bijām iedvesmoti ar mūsu pilotpētījuma sākotnējiem rezultātiem, tika nolemts turpināt veikt pētījumu par dzemdes kakla nepietiekamības kolagenopātisko dabu (FLPP projekts Nr. 2020/1-0042, 2021-2023). Pašlaik tiek izstrādāts pētījuma dizains, tas ietver arī visaptverošu ar kolagēnu saistîto pacientu fenotipisko pazīmju novērtēšanu, ieskaitot iegurņa orgānu prolapsu un urīna simptomu novērtēšanu. Mēs gaidām rezultātus un iespēju tos salīdzināt ar Ben-Zvi atradnēm. 


\subsection{Ieteikumi sieviešu reproduktīvās mazspējas genenētiskajai novērtēšanai pētījumos un klīnikā}

1. Lai droši sasaistîtu pašlaik identificētos gēnus ar sievieties reproduktīvās mazspējas fenotipiem un izmantotu tos kā diagnostikas marķierus klīniskajā praksē, jāveic standartizēta gēnu-slimību klīniskās validitātes novērtēšana.

2. Lai veicinātu sievietes reprodukcijas jomas attīstību un stimulētu personalizētas ārstēšanas piemērošanu tajā, jāatjaunina ǵenētiskās testēšanas labās prakses vadlīnijas traucētas sievietes reprodukcijas gadījumā.

3. Ģenētiskai konsultēšanai vajadzētu pavadīt jebkuru genētisko testēšanu un, vēlams, reproduktīvo tehnologiiju lietošanu, nodrošinot informētu reproduktīvo lēmumu pieņemšanu, lai izvairītos no nelabvēlīgiem reproduktīviem rezultātiem pacientiem un viņu pēcnācējiem.

4. Pêtîjumos un klīniskajā vidē būtu jāveic rūpīga pacienta fenotipēšana, lai nošķirtu pacientus ar sagaidāmiem ǵenētiskiem defektiem no tiem, kuru fenotips ir attiecināms uz ārējiem faktoriem, tādējādi palielinot iespēju atklāt noteiktus g̊enētiskos markiierus.

5. Labi raksturotu gēnu paneḷu ieviešana klīniskajā praksē atvieglos traucētas sievietes reprodukcijas ǵenētisko cēloṇu identificēšanu, izvairoties no nevajadzīgas izmeklēšanas un manipulācijām, samazinot laiku līdz piemērotākam reproduktīvajam risinājumam. 


\subsection{Nobeiguma piezīmes}

Sievietes reproduktīvās mazspējas jumta saucējs aptver ḷoti dažādus un atškirīgus fenotipus, kurus visus var ietekmēt indivīda genētiskais fons. Ģenētiskā testēšana kḷūst aizvien pieprasītāka gandrīz katrā neveiksmīgas sievietes reprodukcijas posmā, sākot no traucētas olnīcu funkcijas un neveiksmīgiem mēginājumiem ieņemt bērnu un beidzot ar zaudētu grūtniecību. Dažas genomiskās tehnologijas ir piemērotas, lai apmierinātu augošās jomas prasības, - katra šīs disertācijas nodaḷa demonstrē, kā konkrētu metodi var droši izmantot reproduktīvā jautājumā. Līdz ar to izvirzītā darba hipotēze mūsdien̄̄gas genētiskās tehnolog̣ijas var tikt veiksmīgi izmantotas dažādu ǵenētisko variāciju ietekmējošu sievietes reproduktīvo potenciālu drošai novērtēšanai - ir apstiprināta.

Es paredzu, ka gēnu skaits, kas atklāts līdz šim, pēc gaidītā sistemātiskā gēnu-slimības klīniskās validitātes novērtējuma būs pamats mērḳa gēnu paneḷu ieviešanai tuvākajā nākotnē. Kopā ar atjauninātām labās prakses vadlīnijām un piemērotu ǵenētisko konsultēšanu tam vajadzētu palielināt pozitīvu diagnožu skaitu un individualizētu reproduktīvo tehnologiju izmantošanu, uzlabojot reproduktīvās medicīnas vispārējo kvalitātes līmeni. Paredzēts, ka sievietes reprodukcijas fenotipi, kas kavē izraisošā gēnu varianta dabisku nodošanu nākamajai paaudzei, ir ḷoti heterogēni (Laissue, 2015). Pelēm vairāk nekā 500 gēnu ir saistīti ar sievietes neauglību, tuvākajos gados daudz vairāk gēnu tiks atklāti cilvēkam (Harper et al., 2018). Lai to panāktu, nepieciešama dažādu pārdomātu genomisko pieeju un izsmalcinātu pētîjuma dizainu izmantošana lielās pacientu grupās ar genomisko variāciju funkcionālu validāciju.

Svarīgi ir tas, ka, pētot populācijas ar inbrīdingu un bez tā, jāpiemēro dažādas pieejas. Inbrīdās populācijās lielākā daḷa izraisošo gēnu variantu ir bialēliski gēnu traucējumi, turpretī populācijās bez raksturīgās tuvradnieciskās 
krustošanās var sagaidīt dažādu ǵenētisko mehānismu kombināciju. Es ticu, ka lielā skaitā gadījumu de novo varianti var būt atbildīgi par sievietes reproduktīvo fenotipu attīstību autbrīdinga populācijās, lai gan š̄ aizraujošā hipotēze ir pienācīgi jāpēta. Turklāt uz šo hipotēzi netieši norāda daži novērojumi, kuri tika iegūti līdz ar ExAC konsorcijas datubāzes analīzi. Respektīvi, cilvēka genomā ir identificēti 3230 gēni, kas ir jutīgi pret funkcijas zudumu, un 72\% no tiem nav saistīta cilvēka slimības fenotipa. Šie gēni ne obligāti ir slimības gēni, bet, iespējams, norāda uz gēniem, kuros heterozigotisks funkcijas zudums ir reproduktīvi neizdevīgs cilvēces vēstures gaitā (Lek et al., 2016).

Līdz šim kopējais identificēto gēnu skaits ar asociētu slimības fenotipu sasniedz vairāk nekā 4000 (OMIM, 2020). Kopumā cilvēka genomā ir vairāk nekā 20000 gēnu, tas nozīmē, ka variantiem vairāk nekā 16000 gēnos bez zināmas klīniskas nozīmes joprojām ir potenciāls būt iesaistītiem sievietes reprodukcijā kā atsevišķam cēlonim vai kompleksā ar citiem gēnu variantiem.

Liels skaits fenotipiskās daudzveidības, kas tagad slēpta mūsu acīm, un tās ǵenētiskā izcelsme vēl tikai tiks atklāta. Piemēram, 30\% grūtniecību tiek zaudētas laikā starp embrija implantāciju un grūtniecības sesto nedēḷu (Jeve \& Davies, 2014; Nybo Andersen et al., 2000), šobrīd šis laika posms ir pilnīgi nepieejams analīzei, tāpat kā embrija-endometrija mijiedarbība. Tāpat nav pētījumu, kas koncentrētos uz mozāicisma iedarbību uz sievietes reproduktīvajiem fenotipiem. Vai tas varētu izskaidrot daļu no priekšlaicīgas olnīcu izsīkšanas fenotipa?

Es ticu, ka turpmākajos gados jaunu gēnu skaits, kas izskaidros sieviešu reproduktīvo mazspēju, strauji palielināsies. Molekulārā un ǵenētiskā pacienta fenotipa izpratne sniegs vēl nebijušu iespēju noteikt jaunus mērķus terapijai vai sievietes reproduktīvās funkcijas preventīvai saglabāšanai, izvirzot personalizētu terapiju reproduktīvās medicīnas priekšplānā. 


\section{Secinājumi}

1. MDA pilna genoma amplifikācijas metode piemērojama viena vai dažu lokusu analīzei, savukārt SurePlex tehnolog̣ija atbilst genomisko tehnologiju prasībām; vienlaikus izmantojot abus amplifikatorus, var veikt daudzpusīgu un drošu pirmsimplantācijas ǵenētisko testēšanu, lai atlasītu embrijus bez viena gēna un hromosomālām patologiijām, veicinot vesela bērna ieṇemšanu.

2. Četrpadsmit mikrosatelītu lokusu analīzes protokols mātes šūnu kontaminācijas noteikšanai kombinācijā ar salīdzinošo genoma hibridizāciju uz mikročipiem novērš nepareižu diagnožu rašanos agrīni pārtraukušās grūtniecības materiāla ǵenētiskajā testēšanā un ietekmē klīnicistu un pacientu informētu lēmumu pieņemšanu turpmākas taktikas izvēlē.

3. Sistemātiskā literatūras un gēnu analīzē tika identificēti 12 primāri ar dzemdes kakla nepietiekamību saistīti gēni, no kuriem lielākā daḷa izraisa kolagenopātijas, tādējādi efektīvi veicinot pacientu nākamās paaudzes sekvencēšanas datu analīzi.

4. Molekulāro gēnu ceḷu bagātināšanas analīze un stingra nākamās paaudzes sekvencēšanā identificēto gēnu un gēnu variantu atlases stratēgiija atklāja paaugstinātu gēnu variācijas slogu molekulārajos ceḷos, kas saistīti ar audu mehānisko un biomehānisko izturību, un lokalizēja 13 variantus gēnos, kuri izraisa kolagenopātijas un potenciāli palielina dzemdes kakla nepietiekamības attīstības varbūtību. 


\section{Publikācijas un ziṇojumi par promocijas darba tēmu}

\section{Zinātniskās publikācijas izdevumos, kas iekḷauti starptautiskajās datubāzēs (Web of Science, SCOPUS, ERIH PLUS)}

1. Perminovs, D., Voložonoka, L., Korṇejeva, L., Jokste-Pīrmane, E., Blumberga, A., Krasucka, S., Seimuškina, N., Kovaḷova, I. and Fodina, V., 2017. First preimplantation genetic testing case for monogenic disease in Latvia. Gynecological Endocrinology, 33(sup1), 47-49.

2. Voložonoka, L., Perminovs, D., Korņejeva, L., Alkšere, B., Novikova, N., Pīmane, E. J., Blumberga, A., Kempa, I., Miskova, A., Gailīte, L. and Fodina, V., 2018. Performance comparison of two whole genome amplification techniques in frame of multifactor preimplantation genetic testing. Journal of assisted reproduction and genetics, 35(8), 1457-1472.

3. Voložonoka, L., Rots, D., Kempa, I., Kornete, A., Rezeberga, D., Gailīte, L. and Miskova, A., 2020. Genetic landscape of preterm birth due to cervical insufficiency: Comprehensive gene analysis and patient next-generation sequencing data interpretation. PloS one, 15(3), e0230771.

4. Voložonoka, L., Gailīte, L., Perminovs, D., Korņejeva, L., Fodina, V., Kempa, I. and Miskova, A., 2020. Reducing misdiagnosis caused by maternal cell contamination in genetic testing for early pregnancy loss. Systems Biology in Reproductive Medicine, 66(6), 410-420.

5. Ludmila Voložonoka, Anna Miskova, Liene Kornejeva, Inga Kempa, Veronika Bargatina, Linda Gailite. A systematic review and standartized clinical validity assessment of genes involved in female reproductive failure. Submitted to Human Reproduction.

\section{Zinātniskās publikācijas Latvijas izdevumos}

1. Voložonoka, L., Korņejeva, L., Miskova, A., Fodina, V., 2015. Preimplantation Genetic Screening - Summary of First Results in Patients with Complicated Reproductive History. Riga Stradins University Scientific Proceedings. (1), 241-45.

\section{Uzstāšanās starptautiskās zinātniskās konferencēs}

1. Voložonoka, L., Korņejeva, L., Novikova, N., Fodina, V. Benefits of combined preimplantation genetic screening and endometrial receptivity assessment on IVF outcome for complicated reproductive history patients. 49th European Human Genetics Conference. Barcelona, Spain. May 21-24, 2016. (Stenda referāts). 
2. Voložonoka, L., Fodina, V., Korņejeva, L. Molecular karyotyping of products of conception - evaluation of performance and capacity. ESHRE 32nd Annual Meeting. Helsinki, Finland. 3-6 July 2016. (Stenda referāts).

3. Voložonoka, L., Perminovs, D., Korn̨ejeva, L., Kempa, I., Miskova, A., Šterna, O., Fodina, V. Preimplantation genetic testing of monogenic diseases and aneiploīdsies using single blastocyst biopsy approach. European Human Genetics Conference. Copenhagen, Denmark, May 27-30, 2017. (Stenda referāts).

4. Voložonoka, L., Perminovs, D., Korṇejeva, L., Alkšere, B., Kempa, I., Miskova, A., Gailīte, L., Fodina, V. Development and application of individualized customizable preimplantation genetic testing algorithm. Balkan Journal of Medical Genetics, ICGEB Workshop Next generation diagnostics, Vol 21, 2018, Supplement 1:71. (Stenda referāts).

5. Voložonoka, L., Kornete, A, Krūmiņa, Z., Rota, A., Gailīte, L., Kempa, I., Rezeberga, D., Miskova, A. Clinical Characterization and Collagenopathic Phenotyping in Preterm Birth due to Cervical Insufficiency. Knowledge for Use in Practice. Riga, Latvia, 24-26 March 2021. (Mutisks ziņojums).

\section{Uzstāšanās vietējas nozīmes zinātniskās konferencēs}

1. Voložonoka, L. Clinical application of embryo preimplantation genetic testing by comparative genomic hybridization on microchips in frame of reproductive medicine. Latvian Obstetrics and Gynecology Specialist Congress. Riga, Latvia, October 16-18, 2014. (Mutisks ziņojums).

2. Voložonoka, L., Miskova, A. Assessing molecular karyotyping applicability in recurrent early pregnancy loss etiology determination. Latvian Obstetrics and Gynecology Specialist Congress. Riga, Latvia, October 16-18, 2014. (Tēzes).

3. Voložonoka, L., Korṇejeva, L., Miskova, A., Fodina, V. Embryo preimplantation genetic screening effectiveness in ART cycles for the patients with burdened reproductive history - first results. Rīga Stradiňš University scientific conference. Riga, Latvia, March 26-27, 2015. (Stenda referāts).

4. Voložonoka, L. Array Comparative Genomic Hybridization application in reproductive genetics. The Second Annual International Reproductive, Genetic \& Biotechnology Conference. Riga, Latvia, 14 October 2016. (Mutisks ziniojums).

5. Voložonoka, L., Gailīte, L., Miskova, A., Kempa, I. Next generation sequencing identifies pathogenic variants in genes involved in collagen production in patients with preterm birth due to precocious cervical ripening. RSU Research Week 2019. Knowledge For Use In Practice. Riga, Latvia, April 1-3, 2019. (Stenda referāts). 


\section{Literatūras saraksts}

1. Agler, C. S. and Divaris, K. 2020. Sources of bias in genomics research of oral and dental traits: [special issue of community dental health, to be disseminated at 'Random and systematic bias in population oral health research' IADR symposium, March 2020, Washington DC.]. Community Dental Health, 37(1), 102-106. https://doi.org/10.1922/CDH_SpecialIssue_Divaris05.

2. AlAsiri, S., Basit, S., Wood-Trageser, M. A., Yatsenko, S. A., Jeffries, E. P., Surti, U., Ketterer, D. M., Afzal, S., Ramzan, K., Faiyaz-Ul Haque, M., Jiang, H., Trakselis, M. A. and Rajkovic, A. 2015. Exome sequencing reveals MCM8 mutation underlies ovarian failure and chromosomal instability. Journal of Clinical Investigation, 125(1), 258-262. https://doi.org/10.1172/JCI78473.

3. Alazami, A. M., Awad, S. M., Coskun, S., Al-Hassan, S., Hijazi, H., Abdulwahab, F. M., Poizat, C. and Alkuraya, F. S. 2015. TLE6 mutation causes the earliest known human embryonic lethality. Genome Biology, 16(1), 1-8. https://doi.org/10.1186/s13059-015-0792-0.

4. Anum, E. A., Hill, L. D., Pandya, A. and Strauss, J. F. 2009. Connective Tissue and Related Disorders and Preterm Birth: Clues to Genes Contributing to Prematurity. Placenta, 30(3), 207-215. https://doi.org/10.1016/j.placenta.2008.12.007.

5. Artymuk, N. V., Belokrinickaya, T. E., Zaharova, U. A., Ksenofontova, O. L., Kulikov, A. V., Leshenko, O. Y., Martirosyan, S. V., Oboskalova, T. A., Olenev, A. S., Perevozkina, O. V., Radzinskiy, V. E., Salimova, I. V., Sevostyanova, O. Y., Simonovskaya, H. Y. Tetruashvili, N. K., and Shifman, E. M. 2019. Истмико-цервикальная недостаточность: распространенность и клинико-анамнестические особенности. Cervical Insufficiency. Clinical Recommendations Treatment Protocol. Акушерство и Гинекология: Новости, Мнения, Обучение, 3(25).

6. Asimit, J. and Zeggini, E. 2010. Rare variant association analysis methods for complex traits. Annual Review of Genetics, 44, 293-308. https://doi.org/ 10.1146/annurev-genet-102209-163421.

7. Awonuga, A., Govindbhai, J., Zierke, S. and Schnauffer, K. 1998. Continuing the debate on empty follicle syndrome: $C$ an it be associated with normal bioavailability of $\beta$-human chorionic gonadotrophin on the day of oocyte recovery? Human Reproduction, 13(5), 1281-1284. https://doi.org/10.1093/humrep/13.5.1281.

8. Beau, I., Touraine, P., Meduri, G., Gougeon, A., Desroches, A., Matuchansky, C., Milgrom, E., Kuttenn, F. and Misrahi, M. 1998. A novel phenotype related to partial loss of function mutations of the follicle stimulating hormone receptor. Journal of Clinical Investigation, 102(7), 1352-1359. https://doi.org/10.1172/JCI3795. 
9. Bell, K. A., van Deerlin, P. G., Haddad, B. R. and Feinberg, R. F. 1999. Cytogenetic diagnosis of "normal 46,XX" karyotypes in spontaneous abortions frequently may be misleading. Fertility and Sterility, 71(2), 334-341. https://doi.org/ 10.1016/S0015-0282(98)00445-2.

10. Ben-Zvi, M., Herman, H. G., Bar, J., Condrea, A. and Ginath, S. 2020. Are women with cervical incompetence at a higher risk of experiencing urinary and pelvic organ prolapse symptoms? International Urogynecology Journal, 31(2), 385-389. https://doi.org/10.1007/s00192-019-03979-w.

11. Bezold, K. Y., Karjalainen, M. K., Hallman, M., Teramo, K. and Muglia, L. J. 2013. The genomics of preterm birth: From animal models to human studies. Genome Medicine, 5(4). https://doi.org/10.1186/gm438.

12. Butler, R., Nakhuda, G., Guimond, C., Jing, C., Lee, N., Hitkari, J., Tallon, N., Taylor, B. and Yuzpe, A. 2019. Analysis of PGT-M and PGT-SR outcomes at a Canadian fertility clinic. Prenatal Diagnosis, 39(10), 866-870. https://doi.org/10.1002/pd.5496.

13. Capalbo, A., Rienzi, L. and Ubaldi, F. M. 2016. New approaches for multifactor preimplantation genetic diagnosis of monogenic diseases and aneuploidies from a single biopsy. Fertility and Sterility, 105(2), 297-298. https://doi.org/10.1016/j.fertnstert.2015.10.039.

14. Cariati, F., D’Argenio, V. and Tomaiuolo, R. 2019. The evolving role of genetic tests in reproductive medicine. In Journal of Translational Medicine, 17(1), 1-33. https://doi.org/10.1186/s12967-019-2019-8.

15. Carley, M. E. and Schaffer, J. 2000. Urinary incontinence and pelvic organ prolapse in women with Marfan or Ehlers-Danlos syndrome. American Journal of Obstetrics and Gynecology, 182(5), 1021-1023. https://doi.org/10.1067/mob.2000.105410.

16. Carp, H. J. A. 2007. Recurrent pregnancy loss: Causes, controversies and treatment. Recurrent Pregnancy Loss: Causes, Controversies and Treatment. CRC press; 2014(Dec 10). https://doi.org/10.1080/14647270701712928.

17. Chen, B., Zhang, Z., Sun, X., Kuang, Y., Mao, X., Wang, X., Yan, Z., Li, B., Xu, Y., Yu, M., Fu, J., Mu, J., Zhou, Z., Li, Q., Jin, L., He, L., Sang, Q. and Wang, L. 2017. Biallelic Mutations in PATL2 Cause Female Infertility Characterized by Oocyte Maturation Arrest. American Journal of Human Genetics, 101(4), 609-615. https://doi.org/10.1016/j.ajhg.2017.08.018.

18. Chen, S. U., Su, Y. N., Fang, M. Y., Chang, L. J., Tsai, Y. Y., Lin, L. T., Lee, C. N. and Yang, Y. S. 2008. PGD of $\beta$-thalassaemia and HLA haplotypes using OmniPlex whole genome amplification. Reproductive BioMedicine Online, 17(5), 699-705. https://doi.org/10.1016/S1472-6483(10)60319-7. 
19. Chen, T., Bian, Y., Liu, X., Zhao, S., Wu, K., Yan, L., Li, M., Yang, Z., Liu, H., Zhao, H. and Chen, Z. J. 2017. A Recurrent Missense Mutation in ZP3 Causes Empty Follicle Syndrome and Female Infertility. American Journal of Human Genetics, 101(3), 459-465. https://doi.org/10.1016/j.ajhg.2017.08.001.

20. Conde-Agudelo, A. and Romero, R. 2016. Vaginal progesterone to prevent preterm birth in pregnant women with a sonographic short cervix: Clinical and public health implications. American Journal of Obstetrics and Gynecology, 214(2), 235-242. https://doi.org/10.1016/j.ajog.2015.09.102.

21. Coulam, C. B., Bustillo, M. and Schulman, J. D. 1986. Empty follicle syndrome. Fertility and Sterility, 46(6), 1153-1155. https://doi.org/10.1016/S00150282(16)49898-5.

22. Dahdouh, E. M., Balayla, J., Audibert, F., Wilson, R. D., Brock, J. A., Campagnolo, C., Carroll, J., Chong, K., Gagnon, A., Johnson, J. A., MacDonald, W., Okun, N., Pastuck, M. and Vallée-Pouliot, K. 2015. Technical Update: Preimplantation Genetic Diagnosis and Screening. Journal of Obstetrics and Gynaecology Canada, 37(5), 451-463. https://doi.org/10.1016/S1701-2163(15)30261-9.

23. Dai, C., Hu, L., Gong, F., Tan, Y., Cai, S., Zhang, S., Dai, J., Lu, C., Chen, J., Chen, Y., Lu, G., Du, J. and Lin, G. 2019. ZP2 pathogenic variants cause in vitro fertilization failure and female infertility. Genetics in Medicine, 21(2), 431-440. https://doi.org/10.1038/s41436-018-0064-y.

24. Davis, A. R., Horvath, S. K. and Castaño, P. M. 2017. Trends in gestational age at time of surgical abortion for fetal aneuploidy and structural abnormalities. American Journal of Obstetrics and Gynecology, 216(3), 278.e1-278.e5. https://doi.org/10.1016/j.ajog.2016.10.031.

25. De Roux, N., Young, J., Misrahi, M., Genet, R., Chanson, P., Schaison, G. and Milgrom, E. 1997. A Family with Hypogonadotropic Hypogonadism and Mutations in the Gonadotropin-Releasing Hormone Receptor. New England Journal of Medicine, 337(22), 1597-1603. https://doi.org/10.1056/nejm199711273372205.

26. Di Renzo, G. C. 2015. Best practice in maternal-fetal medicine. International Journal of Gynecology and Obstetrics, 128(1), 80-82. https://doi.org/ 10.1016/j.ijgo.2014.10.011.

27. Edwards, J. G., Feldman, G., Goldberg, J., Gregg, A. R., Norton, M. E., Rose, N. C., Schneider, A., Stoll, K., Wapner, R. and Watson, M. S. 2015. Expanded carrier screening in reproductive medicine-points to consider. Obstetrics and Gynecology, 125(3), 653-662. https://doi.org/10.1097/AOG.0000000000000666. 
28. Eiben, B., Bartels, I., Bahr-Porsch, S., Borgmann, S., Gatz, G., Gellert, G., Goebel, R., Hammans, W., Hentemann, M., Osmers, R., Rauskolb, R. and Hansmann, I. 1990. Cytogenetic analysis of 750 spontaneous abortions with the direct-preparation method of chorionic villi and its implications for studying genetic causes of pregnancy wastage. American Journal of Human Genetics, 47(4), 656-663.

29. Feng, R., Yan, Z., Li, B., Yu, M., Sang, Q., Tian, G., Xu, Y., Chen, B., Qu, R., Sun, Z., Sun, X., Jin, L., He, L., Kuang, Y., Cowan, N. J. and Wang, L. 2016. Mutations in TUBB8 cause a multiplicity of phenotypes in human oocytes and early embryos. Journal of Medical Genetics, 53(10), 662-671. https://doi.org/10.1136/jmedgenet2016-103891.

30. Ford, C. E., Jones, K. W., Polani, P. E., de Almeida, J. C. and Briggs, J. H. 1959. a Sex-Chromosome Anomaly in a Case of Gonadal Dysgenesis Turner'S Syndrome. The Lancet, 273(7075), 711-713. https://doi.org/10.1016/S0140-6736(59)91893-8.

31. França, M. M., Funari, M. F. A., Nishi, M. Y., Narcizo, A. M., Domenice, S., Costa, E. M. F., Lerario, A. M. and Mendonca, B. B. 2018. Identification of the first homozygous 1-bp deletion in GDF9 gene leading to primary ovarian insufficiency by using targeted massively parallel sequencing. Clinical Genetics, 93(2), 408-411. https://doi.org/10.1111/cge.13156.

32. Freed, D., Aldana, R., Weber, J. A. and Edwards, J. S. 2017. The Sentieon Genomics Tools - A fast and accurate solution to variant calling from next-generation sequence data. BioRxiv. https://doi.org/10.1101/115717.

33. Gaasenbeek, M., Powell, B. L., Sovio, U., Haddad, L., Gharani, N., Bennett, A., Groves, C. J., Rush, K., Goh, M. J., Conway, G. S., Ruokonen, A., Martikainen, H., Pouta, A., Taponen, S., Hartikainen, A. L., Halford, S., Järvelin, M. R., Franks, S. and McCarthy, M. I. 2004. Large-Scale Analysis of the Relationship between CYP11A Promoter Variation, Polycystic Ovarian Syndrome, and Serum Testosterone. Journal of Clinical Endocrinology and Metabolism, 89(5), 2408-2413. https://doi.org/10.1210/jc.2003-031640.

34. Gekas, J., Thepot, F., Turleau, C., Siffroi, J. P., Dadoune, J. P., Briault, S., Rio, M., Bourouillou, G., Carré-Pigeon, F., Wasels, R., Benzacken, B., Montagnon, M., Rives, N., Clotteau, L., Malingue, M. C., Darabi, P., Poitot, C., Baverel, F., Lesourd, S., Cartault, F. 2001. Chromosomal factors of infertility in candidate couples for ICSI: An equal risk of constitutional aberrations in women and men. Human Reproduction, 16(1), 82-90. https://doi.org/10.1093/humrep/16.1.82.

35. Goldenberg, R. L., Gravett, M. G., Iams, J., Papageorghiou, A. T., Waller, S. A., Kramer, M., Culhane, J., Barros, F., Conde-Agudelo, A., Bhutta, Z. A., Knight, H. E. and Villar, J. 2012. The preterm birth syndrome: Issues to consider in creating a classification system. American Journal of Obstetrics and Gynecology, 206(2), 113-118. https://doi.org/10.1016/j.ajog.2011.10.865. 
36. Handyside, A. H., Robinson, M. D., Simpson, R. J., Omar, M. B., Shaw, M. A., Grudzinskas, J. G. and Rutherford, A. 2004. Isothermal whole genome amplification from single and small numbers of cells: A new era for preimplantation genetic diagnosis of inherited disease. Molecular Human Reproduction, 10(10), 767-772. https://doi.org/10.1093/molehr/gah101.

37. Harper, J. C., Aittomäki, K., Borry, P., Cornel, M. C., de Wert, G., Dondorp, W., Geraedts, J., Gianaroli, L., Ketterson, K., Liebaers, I., Lundin, K., Mertes, H., Morris, M., Pennings, G., Sermon, K., Spits, C., Soini, S., van Montfoort, A. P. A., Veiga, A., Macek, M. 2018. Recent developments in genetics and medically assisted reproduction: From research to clinical applications. European Journal of Human Genetics, 26(1), 12-33. https://doi.org/10.1038/s41431-017-0016-z.

38. Harton, G. L., de Rycke, M., Fiorentino, F., Moutou, C., Sengupta, S., TraegerSynodinos, J. and Harper, J. C. 2011. ESHRE PGD consortium best practice guidelines for amplification-based PGD. Human Reproduction, 26(1), 33-40. https://doi.org/10.1093/humrep/deq231.

39. Hassold, T., Quillen, S. D. and Yamane, J. A. 1983. Sex ratio in spontaneous abortions. Annals of Human Genetics, 47(1), 39-47. https://doi.org/10.1111/j.14691809.1983.tb00968.x.

40. Heazell, A. E. P., Newman, L., Lean, S. C. and Jones, R. L. 2018. Pregnancy outcome in mothers over the age of 35. Current Opinion in Obstetrics and Gynecology, 30(6), 337-343. https://doi.org/10.1097/GCO.0000000000000494.

41. Hellani, A., Coskun, S., Tbakhi, A. and Al-Hassan, S. 2004. The Preimplantation Genetic Diagnosis International Society PGDIS): Guidelines for good practice in PGD. Reproductive BioMedicine Online, 9(4), 430-434. https://doi.org/ 10.1016/S1472-6483(10)61279-5.

42. Huang, H.-L., Lv, C., Zhao, Y.-C., Li, W., He, X.-M., Li, P., Sha, A.-G., Tian, X., Papasian, C. J., Deng, H.-W., Lu, G.-X. and Xiao, H.-M. 2014. Mutant ZP1 in Familial Infertility. New England Journal of Medicine, 370(13), 1220-1226. https://doi.org/10.1056/nejmoa1308851.

43. Huang, L., Tong, X., Luo, L., Zheng, S., Jin, R., Fu, Y., Zhou, G., Li, D. and Liu, Y. 2017. Mutation analysis of the TUBB8 gene in nine infertile women with oocyte maturation arrest. Reproductive BioMedicine Online, 35(3), 305-310. https://doi.org/10.1016/j.rbmo.2017.05.017.

44. Inhorn, M. C. and Patrizio, P. 2014. Infertility around the globe: New thinking on gender, reproductive technologies and global movements in the 21st century. Human Reproduction Update, 21(4), 411-426. https://doi.org/10.1093/humupd/dmv016. 
45. Jarrett, K. L., Michaelis, R. C., Phelan, M. C., Vincent, V. A. and Best, R. G. 2001. Microsatellite analysis reveals a high incidence of maternal cell contamination in 46,XX products of conception consisting of villi or a combination of villi and membranous material. American Journal of Obstetrics and Gynecology, 185(1), 198-203. https://doi.org/10.1067/mob.2001.114692.

46. Jeve, Y. B. and Davies, W. 2014. Evidence-based management of recurrent miscarriages. Journal of Human Reproductive Sciences, 7(3), 159-169. https://doi.org/10.4103/0974-1208.142475.

47. Kamburov, A., Stelzl, U., Lehrach, H. and Herwig, R. 2013. The ConsensusPathDB interaction database: 2013 Update. Nucleic Acids Research, 41(1), 793-800. https://doi.org/10.1093/nar/gks1055.

48. Kendig, K. I., Baheti, S., Bockol, M. A., Drucker, T. M., Hart, S. N., Heldenbrand, J. R., Hernaez, M., Hudson, M. E., Kalmbach, M. T., Klee, E. W., Mattson, N. R., Ross, C. A., Taschuk, M., Wieben, E. D., Wiepert, M., Wildman, D. E. and Mainzer, L. S. 2019. SentIeon DNaSeq variant calling workflow demonstrates strong computational performance and accuracy. Frontiers in Genetics, 10(JUL), 736. https://doi.org/10.3389/fgene.2019.00736.

49. Kniss, D. A. and Summerfield, T. L. 2020. Progesterone Receptor Signaling Selectively Modulates Cytokine-Induced Global Gene Expression in Human Cervical Stromal Cells. Frontiers in Genetics, 2020(11). https://doi.org/ 10.3389/fgene.2020.00883.

50. Kovanci, E., Rohozinski, J., Simpson, J. L., Heard, M. J., Bishop, C. E. and Carson, S. A. 2007. Growth differentiating factor-9 mutations may be associated with premature ovarian failure. Fertility and Sterility, 87(1), 143-146. https://doi.org/10.1016/j.fertnstert.2006.05.079.

51. Kudesia, R., Li, M., Smith, J., Patel, A. and Williams, Z. 2014. Rescue karyotyping: A case series of array-based comparative genomic hybridization evaluation of archival conceptual tissue. Reproductive Biology and Endocrinology, 12(1), 1-8. https://doi.org/10.1186/1477-7827-12-19.

52. Laissue, P. 2015. Aetiological coding sequence variants in non-syndromic premature ovarian failure: From genetic linkage analysis to next generation sequencing. Molecular and Cellular Endocrinology, 411, 243-257. https://doi.org/ 10.1016/j.mce.2015.05.005.

53. Laissue, P., Christin-Maitre, S., Touraine, P., Kuttenn, F., Ritvos, O., Aittomaki, K., Bourcigaux, N., Jacquesson, L., Bouchard, P., Frydman, R., Dewailly, D., Reyss, A. C., Jeffery, L., Bachelot, A., Massin, N., Fellous, M. and Veitia, R. A. 2006. Mutations and sequence variants in GDF9 and BMP15 in patients with premature ovarian failure. European Journal of Endocrinology, 154(5), 739-744. https://doi.org/10.1530/eje.1.02135. 
55. Lathi, R. B., Gustin, S. L. F., Keller, J., Maisenbacher, M. K., Sigurjonsson, S., Tao, R. and Demko, Z. 2014. Reliability of 46,XX results on miscarriage specimens: A review of 1,222 first-trimester miscarriage specimens. Fertility and Sterility, 101(1), 178-182. https://doi.org/10.1016/j.fertnstert.2013.09.031.

56. Lathi, R. B., Loring, M., Massie, J. A. M., Demko, Z. P., Johnson, D., Sigurjonsson, S., Gemelos, G. and Rabinowitz, M. 2012. Informatics enhanced SNP microarray analysis of 30 miscarriage samples compared to routine cytogenetics. PLOS ONE, 7(3), p.e31282. https://doi.org/10.1371/journal.pone.0031282.

57. Layman, L. C. 2013. The genetic basis of female reproductive disorders: Etiology and clinical testing. Molecular and Cellular Endocrinology, 370(1-2), 138-148. https://doi.org/10.1016/j.mce.2013.02.016.

58. Layman, L. C., Lee, E.-J., Peak, D. B., Namnoum, A. B., Vu, K. V., van Lingen, B. L., Gray, M. R., McDonough, P. G., Reindollar, R. H. and Jameson, J. L. 1997. Delayed Puberty and Hypogonadism Caused by Mutations in the FollicleStimulating Hormone $\beta$-Subunit Gene. New England Journal of Medicine, 337(9), 607-611. https://doi.org/10.1056/nejm199708283370905.

59. Le Quesne-Stabej, P., Williams, H. J., James, C., Tekman, M., Stanescu, H. C., Kleta, R., Ocaka, L., Lescai, F., Storr, H. L., Bitner-Glindzicz, M., Bacchelli, C., Conway, G. S. and Sgene, G. O. 2016. STAG3 truncating variant as the cause of primary ovarian insufficiency. European Journal of Human Genetics, 24(1), 135- 138. https://doi.org/10.1038/ejhg.2015.107.

60. Lek, M., Karczewski, K. J., Minikel, E. V., Samocha, K. E., Banks, E., Fennell, T., O’Donnell-Luria, A. H., Ware, J. S., Hill, A. J., Cummings, B. B., Tukiainen, T., Birnbaum, D. P., Kosmicki, J. A., Duncan, L. E., Estrada, K., Zhao, F., Zou, J., Pierce-Hoffman, E., Berghout, J., Williams, A. L. 2016. Analysis of protein-coding genetic variation in 60,706 humans. Nature, 536(7616), 285-291. https://doi.org/10.1038/nature19057.

61. Levy, S., Sutton, G., Ng, P. C., Feuk, L., Halpern, A. L., Walenz, B. P., Axelrod, N., Huang, J., Kirkness, E. F., Denisov, G., Lin, Y., MacDonald, J. R., Pang, A. W. C., Shago, M., Stockwell, T. B., Tsiamouri, A., Bafna, V., Bansal, V., Kravitz, S. A., Venter, J. C. 2007. The diploid genome sequence of an individual human. PLoS Biology, 5(10), 2113-2144. https://doi.org/10.1371/journal.pbio.0050254.

62. Lin, J., Xu, H., Chen, B., Wang, W., Wang, L., Sun, X. and Sang, Q. 2020. Expanding the genetic and phenotypic spectrum of female infertility caused by TLE6 mutations. Journal of Assisted Reproduction and Genetics, 37(2), 437-442. https://doi.org/10.1007/s10815-019-01653-0.

63. Liu, X., Zhao, Y., Pawlyk, B., Damaser, M. and Li, T. 2006. Failure of elastic fiber homeostasis leads to pelvic floor disorders. American Journal of Pathology, 168(2), 519-528. https://doi.org/10.2353/ajpath.2006.050399. 
65. Liu, Z., Zhu, L., Wang, J., Luo, G., Xi, Q., Zhou, X., Li, Z., Yang, X., Duan, J., Jin, L. and Zhang, X. 2020. Novel homozygous mutations in PATL2 lead to female infertility with oocyte maturation arrest. Journal of Assisted Reproduction and Genetics, 37(4), 841-847. https://doi.org/10.1007/s10815-020-01698-6.

66. Lomax, B., Tang, S., Separovic, E., Phillips, D., Hillard, E., Thomson, T. and Kalousek, D. K. 2000. Comparative genomic hybridization in combination with flow cytometry improves results of cytogenetic analysis of spontaneous abortions. American Journal of Human Genetics, 66(5), 1516-1521. https://doi.org/ $10.1086 / 302878$.

67. Maddirevula, S., Awartani, K., Coskun, S., AlNaim, L. F., Ibrahim, N., Abdulwahab, F., Hashem, M., Alhassan, S. and Alkuraya, F. S. 2020. A genomics approach to females with infertility and recurrent pregnancy loss. Human Genetics, 139(5), 605-613. https://doi.org/10.1007/s00439-020-02143-5.

68. McGee, E. A. and Hsueh, A. J. W. 2000. Initial and cyclic recruitment of ovarian follicles. Endocrine Reviews, 21(2), 200-214. https://doi.org/10.1210/er.21.2.200.

69. Mingione, M. J., Scibetta, J. J., Sanko, S. R. and Phipps, W. R. 2003. Clinical outcomes following interval laparoscopic transabdominal cervico-isthmic cerclage placement: Case series. Human Reproduction, 18(8), 1716-1719. https://doi.org/10.1093/humrep/deg345.

70. Mitri, F., Bentov, Y., Behan, L. A., Esfandiari, N. and Casper, R. F. 2014. A novel compound heterozygous mutation of the luteinizing hormone receptor Implications for fertility. Journal of Assisted Reproduction and Genetics, 31(7), 787-794. https://doi.org/10.1007/s10815-014-0249-5.

71. Moher, D., Liberati, A., Tetzlaff, J. and Altman, D. G. 2009. Preferred reporting items for systematic reviews and meta-analyses: the PRISMA statement. Journal of Clinical Epidemiology, 62(10), 1006-1012. https://doi.org/ 10.1016/j.jclinepi.2009.06.005.

72. Montanelli, L., Delbaere, A., di Carlo, C., Nappi, C., Smits, G., Vassart, G. and Costagliola, S. 2004. A mutation in the follicle-stimulating hormone receptor as a cause of familial spontaneous ovarian hyperstimulation syndrome. Journal of Clinical Endocrinology and Metabolism, 89(3), 1255-1258. https://doi.org/ 10.1210/jc.2003-031910.

73. Mu, J., Wang, W., Chen, B., Wu, L., Li, B., Mao, X., Zhang, Z., Fu, J., Kuang, Y., Sun, X., Li, Q., Jin, L., He, L., Sang, Q. and Wang, L. 2019. Mutations in NLRP2 and NLRP5 cause female infertility characterised by early embryonic arrest. Journal of Medical Genetics, 56(7), 471-480. https://doi.org/10.1136/jmedgenet2018-105936.

74. Murdoch, S., Djuric, U., Mazhar, B., Seoud, M., Khan, R., Kuick, R., Bagga, R., Kircheisen, R., Ao, A., Ratti, B., Hanash, S., Rouleau, G. A. and Slim, R. 2006. Mutations in NALP7 cause recurrent hydatidiform moles and reproductive wastage in humans. Nature Genetics, 38(3), 300-302. https://doi.org/10.1038/ng1740. 
75. Nguyen, N. M. P., Ge, Z. J., Reddy, R., Fahiminiya, S., Sauthier, P., Bagga, R., Sahin, F. I., Mahadevan, S., Osmond, M., Breguet, M., Rahimi, K., Lapensee, L., Hovanes, K., Srinivasan, R., van den Veyver, I. B., Sahoo, T., Ao, A., Majewski, J., Taketo, T. and Slim, R. 2018. Causative Mutations and Mechanism of Androgenetic Hydatidiform Moles. American Journal of Human Genetics, 103(5), 740-751. https://doi.org/10.1016/j.ajhg.2018.10.007.

76. Nikitina, T. V., Lebedev, I. N., Sukhanova, N. N., Sazhenova, E. A. and Nazarenko, S. A. 2005. A mathematical model for evaluation of maternal cell contamination in cultured cells from spontaneous abortions: Significance for cytogenetic analysis of prenatal selection factors. Fertility and Sterility, 83(4), 964-972. https://doi.org/10.1016/j.fertnstert.2004.12.009.

77. Norling, A., Hirschberg, A. L., Rodriguez-Wallberg, K. A., Iwarsson, E., Wedell, A. and Barbaro, M. 2014. Identification of a duplication within the GDF9 gene and novel candidate genes for primary ovarian insufficiency POI) by a customized highresolution array comparative genomic hybridization platform. Human Reproduction, 29(8), 1818-1827. https://doi.org/10.1093/humrep/deu149.

78. Nybo Andersen, A. M., Wohlfahrt, J., Christens, P., Olsen, J. and Melbye, M. 2000. Maternal age and fetal loss: Population based register linkage study. British Medical Journal, 320(7251), 1708-1712. https://doi.org/10.1136/bmj.320.7251.1708.

79. OMIM. 2020. OMIM Gene Map Statistics. Online Mendelian Inheritance in Man. https://www.omim.org/statistics/geneMap.

80. Parry, D. A., Logan, C. V., Hayward, B. E., Shires, M., Landolsi, H., Diggle, C., Carr, I., Rittore, C., Touitou, I., Philibert, L., Fisher, R. A., Fallahian, M., Huntriss, J. D., Picton, H. M., Malik, S., Taylor, G. R., Johnson, C. A., Bonthron, D. T. and Sheridan, E. G. 2011. Mutations causing familial biparental hydatidiform mole implicate C6orf221 as a possible regulator of genomic imprinting in the human oocyte. American Journal of Human Genetics, 89(3), 451-458. https://doi.org/ 10.1016/j.ajhg.2011.08.002.

81. Philibert, P., Biason-Lauber, A., Rouzier, R., Pienkowski, C., Paris, F., Konrad, D., Schoenle, E. and Sultan, C. 2008. Identification and functional analysis of a new WNT4 gene mutation among 28 adolescent girls with primary amenorrhea and Müllerian duct abnormalities: A French collaborative study. Journal of Clinical Endocrinology and Metabolism, 93(3), 895-900. https://doi.org/10.1210/jc.20072023.

82. Piyamongkol, W., Bermúdez, M. G., Harper, J. C. and Wells, D. 2003. Detailed investigation of factors influencing amplification efficiency and allele drop-out in single cell PCR: Implications for preimplantation genetic diagnosis. Molecular Human Reproduction, 9(7-8), 411-420. https://doi.org/10.1093/molehr/gag051.

83. Polychronakos, C. 2008. Common and rare alleles as causes of complex phenotypes. Current Atherosclerosis Reports, 10(3), 194-200. https://doi.org/10.1007/s11883008-0031-1. 
84. Rechitsky, S., Pakhalchuk, T., San Ramos, G., Goodman, A., Zlatopolsky, Z. and Kuliev, A. 2015. First systematic experience of preimplantation genetic diagnosis for single-gene disorders, and/or preimplantation human leukocyte antigen typing, combined with 24-chromosome aneuploidy testing. Fertility and Sterility, 103(2), 503-512. https://doi.org/10.1016/j.fertnstert.2014.11.007.

85. Reichman, D. E., White, P. C., New, M. I. and Rosenwaks, Z. 2014. Fertility in patients with congenital adrenal hyperplasia. Fertility and Sterility, 101(2), 301-309. https://doi.org/10.1016/j.fertnstert.2013.11.002.

86. Renwick, P. J., Trussler, J., Ostad-Saffari, E., Fassihi, H., Black, C., Braude, P., Ogilvie, C. M. and Abbs, S. 2006. Proof of principle and first cases using preimplantation genetic haplotyping - A paradigm shift for embryo diagnosis. Reproductive BioMedicine Online, 13(1), 110-119. https://doi.org/10.1016/S14726483(10)62024-X.

87. Rezaei, M., Nguyen, N. M. P., Foroughinia, L., Dash, P., Ahmadpour, F., Verma, I. C., Slim, R. and Fardaei, M. 2016. Two novel mutations in the KHDC3L gene in Asian patients with recurrent hydatidiform mole. Human Genome Variation, 3(1), 1-5. https://doi.org/10.1038/hgv.2016.27.

88. Richards, S., Aziz, N., Bale, S., Bick, D., Das, S., Gastier-Foster, J., Grody, W. W., Hegde, M., Lyon, E., Spector, E., Voelkerding, K. and Rehm, H. L. 2015. Standards and guidelines for the interpretation of sequence variants: A joint consensus recommendation of the American College of Medical Genetics and Genomics and the Association for Molecular Pathology. Genetics in Medicine, 17(5), 405-424. https://doi.org/10.1038/gim.2015.30.

89. Romero, S. T., Geiersbach, K. B., Paxton, C. N., Rose, N. C., Schisterman, E. F., Branch, D. W. and Silver, R. M. 2015. Differentiation of genetic abnormalities in early pregnancy loss. Ultrasound in Obstetrics and Gynecology, 45(1), 89-94. https://doi.org/10.1002/uog.14713.

90. Sambrook, J. and W Russell, D. 2001. Molecular Cloning: A Laboratory Manual. Cold Spring Harbor Laboratory Press, Cold Spring Harbor, NY, 999.

91. Sang, Q., Li, B., Kuang, Y., Wang, X., Zhang, Z., Chen, B., Wu, L., Lyu, Q., Fu, Y., Yan, Z., Mao, X., Xu, Y., Mu, J., Li, Q., Jin, L., He, L. and Wang, L. 2018. Homozygous Mutations in WEE2 Cause Fertilization Failure and Female Infertility. American Journal of Human Genetics, 102(4), 649-657. https://doi.org/10.1016/j.ajhg.2018.02.015.

92. Sang, Q., Zhang, Z., Shi, J., Sun, X., Li, B., Yan, Z., Xue, S., Ai, A., Lyu, Q., Li, W., Zhang, J., Wu, L., Mao, X., Chen, B., Mu, J., Li, Q., Du, J., Sun, Q., Jin, L., Wang, L. 2019. A pannexin 1 channelopathy causes human oocyte death. Science Translational Medicine, 11(485). https://doi.org/10.1126/scitranslmed.aav8731. 
93. Sermon, K. 2017. Novel technologies emerging for preimplantation genetic diagnosis and preimplantation genetic testing for aneuploidy. Expert Review of Molecular Diagnostics, 17(1), 71-82. https://doi.org/ 10.1080/14737159.2017.1262261.

94. Shen, J., Wu, W., Gao, C., Ochin, H., Qu, D., Xie, J., Gao, L., Zhou, Y., Cui, Y. and Liu, J. 2016. Chromosomal copy number analysis on chorionic villus samples from early spontaneous miscarriages by high throughput genetic technology. Molecular Cytogenetics, 9(1), 1-7. https://doi.org/10.1186/s13039-015-0210-z.

95. Singh, J. 2004. Centers for disease control and prevention. Indian Journal of Pharmacology, 36(4), 268-269.

96. Smits, G., Olatunbosun, O., Delbaere, A., Pierson, R., Vassart, G. and Costagliola, S. 2003. Ovarian Hyperstimulation Syndrome Due to a Mutation in the FollicleStimulating Hormone Receptor. New England Journal of Medicine, 349(8), 760- 766. https://doi.org/10.1056/nejmoa030064.

97. Steptoe, P. C. and Edwards, R. G. 1978. Birth after the reimplantation of a human embryo. Lancet, 2(8085), 366. https://doi.org/10.1016/s0140-6736(78)92957-4.

98. Strauss, J. F., Romero, R., Gomez-Lopez, N., Haymond-Thornburg, H., Modi, B. P., Teves, M. E., Pearson, L. N., York, T. P. and Schenkein, H. A. 2018. Spontaneous preterm birth: advances toward the discovery of genetic predisposition. American Journal of Obstetrics and Gynecology, 218(3), 294-314.e2. https://doi.org/10.1016/j.ajog.2017.12.009.

99. Sun, L., Fang, X., Chen, Z., Zhang, H., Zhang, Z., Zhou, P., Xue, T., Peng, X., Zhu, Q., Yin, M., Liu, C., Deng, Y., Hu, H. and Li, N. 2019. Compound heterozygous ZP1 mutations cause empty follicle syndrome in infertile sisters. Human Mutation, 40(11), 2001-2006. https://doi.org/10.1002/humu.23864.

100. Telenius, H., Carter, N. P., Bebb, C. E., Nordenskjöld, M., Ponder, B. A. J. and Tunnacliffe, A. 1992. Degenerate oligonucleotide-primed PCR: General amplification of target DNA by a single degenerate primer. Genomics, 13(3), 718- 725. https://doi.org/10.1016/0888-7543(92)90147-K.

101. Tenenbaum-Rakover, Y., Weinberg-Shukron, A., Renbaum, P., Lobel, O., Eideh, H., Gulsuner, S., Dahary, D., Abu-Rayyan, A., Kanaan, M., Levy-Lahad, E., Bercovich, D. and Zangen, D. 2015. Minichromosome maintenance complex component 8 MCM8) gene mutations result in primary gonadal failure. Journal of Medical Genetics, 52(6), 391-399. https://doi.org/10.1136/jmedgenet2014-102921.

102. Theobald, R., SenGupta, S. and Harper, J. 2020. The status of preimplantation genetic testing in the UK and USA. Human Reproduction Oxford, England), 35(4), 986-998. https://doi.org/10.1093/humrep/deaa034. 
103. Toft, C. L. F., Ingerslev, H. J., Kesmodel, U. S., Diemer, T., Degn, B., Ernst, A., Okkels, H., Kjartansdóttir, K. R. and Pedersen, I. S. 2020. A systematic review on concurrent aneuploidy screening and preimplantation genetic testing for hereditary disorders: What is the prevalence of aneuploidy and is there a clinical effect from aneuploidy screening? Acta Obstetricia et Gynecologica Scandinavica, 99(6), 696- 706. https://doi.org/10.1111/aogs.13823.

104. Tomlinson, I. P. M., Alam, N. A., Rowan, A. J., Barclay, E., Jaeger, E. E. M., Kelsell, D., Leigh, I., Gorman, P., Lamlum, H., Rahman, S., Roylance, R. R., Olpin, S., Bevan, S., Barker, K., Hearle, N., Houlston, R. S., Kiuru, M., Lehtonen, R., Karhu, A., Aaltonen, L. A. 2002. Germline mutations in FH predispose to dominantly inherited uterine fibroids, skin leiomyomata and papillary renal cell cancer the multiple leiomyoma consortium. Nature Genetics, 30(4), 406-410. https://doi.org/10.1038/ng849.

105. Uda, A., Tanabayashi, K., Fujita, O., Hotta, A., Yamamoto, Y. and Yamada, A. 2007. Comparison of whole genome amplification methods for detecting pathogenic bacterial genomic DNA using microarray. Japanese Journal of Infectious Diseases, 60(6), 355-361.

106. Unluturk, U., Harmanci, A., Kocaefe, C. and Yildiz, B. O. 2007. The genetic basis of the polycystic ovary syndrome: A literature review including discussion of PPAR- $\gamma$. In PPAR Research, 2007(Oct). https://doi.org/10.1155/2007/49109.

107. Van den Veyver, I. B. and Al-Hussaini, T. K. 2006. Biparental hydatidiform moles: A maternal effect mutation affecting imprinting in the offspring. Human Reproduction Update, 12(3), 233-242. https://doi.org/10.1093/humupd/dmk005.

108. Vanneste, E., Voet, T., Le Caignec, C., Ampe, M., Konings, P., Melotte, C., Debrock, S., Amyere, M., Vikkula, M., Schuit, F., Fryns, J. P., Verbeke, G., D'Hooghe, T., Moreau, Y. and Vermeesch, J. R. 2009. Chromosome instability is common in human cleavage-stage embryos. Nature Medicine, 15(5), 577-583. https://doi.org/10.1038/nm.1924.

109. Vanneste, E., Voet, T., Melotte, C., Debrock, S., Sermon, K., Staessen, C., Liebaers, I., Fryns, J. P., D'Hooghe, T. and Vermeesch, J. R. 2009. What next for preimplantation genetic screening? High mitotic chromosome instability rate provides the biological basis for the low success rate. Human Reproduction, 24(11), 2679-2682. https://doi.org/10.1093/humrep/dep266.

110. Vasseur, C., Rodien, P., Beau, I., Desroches, A., Gérard, C., de Poncheville, L., Chaplot, S., Savagner, F., Croué, A., Mathieu, E., Lahlou, N., Descamps, P. and Misrahi, M. 2003. A Chorionic Gonadotropin-Sensitive Mutation in the FollicleStimulating Hormone Receptor as a Cause of Familial Gestational Spontaneous Ovarian Hyperstimulation Syndrome. New England Journal of Medicine, 349(8), 753-759. https://doi.org/10.1056/nejmoa030065.

111. Vink, J. and Myers, K. 2018. Cervical alterations in pregnancy. In Best Practice and Research: Clinical Obstetrics and Gynaecology, 52, 88-102. https://doi.org/10.1016/j.bpobgyn.2018.03.007. 
112. Wang, A. C., Zhang, Y. S., Wang, B. S., Zhao, X. Y., Wu, F. X., Zhai, X. H., Sun, J. X. and Mei, S. Y. 2018. Mutation analysis of the TUBB8 gene in primary infertile women with arrest in oocyte maturation. Gynecological Endocrinology, 34(10), 900-904. https://doi.org/10.1080/09513590.2018.1464138.

113. Wang, S. W., Ma, L. L., Huang, S., Liang, L. and Zhang, J. R. 2016. Role of cervical cerclage and vaginal progesterone in the treatment of cervical incompetence with/without preterm birth history. Chinese Medical Journal, 129(22), 2670-2675. https://doi.org/10.4103/0366-6999.193451.

114. Williams, L. S., Demir Eksi, D., Shen, Y., Lossie, A. C., Chorich, L. P., Sullivan, M. E., Phillips, J. A., Erman, M., Kim, H. G., Alper, O. M. and Layman, L. C. 2017. Genetic analysis of Mayer-Rokitansky-Kuster-Hauser syndrome in a large cohort of families. Fertility and Sterility, 108(1), 145-151.e2. https://doi.org/10.1016/j.fertnstert.2017.05.017.

115. Witchel, S. F. and Aston, C. E. 2000. The role of heterozygosity for CYP21 in the polycystic ovary syndrome. Journal of Pediatric Endocrinology and Metabolism, 13(suppl. 5), 1315-1317.

116. Wood-Trageser, M. A., Gurbuz, F., Yatsenko, S. A., Jeffries, E. P., Kotan, L. D., Surti, U., Ketterer, D. M., Matic, J., Chipkin, J., Jiang, H., Trakselis, M. A., Topaloglu, A. K. and Rajkovic, A. 2014. MCM9 mutations are associated with ovarian failure, short stature, and chromosomal instability. American Journal of Human Genetics, 95(6), 754-762. https://doi.org/10.1016/j.ajhg.2014.11.002.

117. Word, R. A., Li, X. H., Hnat, M. and Carrick, K. 2007. Dynamics of cervical remodeling during pregnancy and parturition: Mechanisms and current concepts. Seminars in Reproductive Medicine, 25(1), 69-79. https://doi.org/10.1055/s-2006956777.

118. Wu, L., Chen, H., Li, D., Song, D., Chen, B., Yan, Z., lyu, Q., Wang, L., Kuang, Y., Li, B. and Sang, Q. 2019. Novel mutations in PATL2: expanding the mutational spectrum and corresponding phenotypic variability associated with female infertility. Journal of Human Genetics, 64(5), 379-385. https://doi.org/10.1038/s10038-019-0568-6.

119. Xu, Y., Shi, Y., Fu, J., Yu, M., Feng, R., Sang, Q., Liang, B., Chen, B., Qu, R., Li, B., Yan, Z., Mao, X., Kuang, Y., Jin, L., He, L., Sun, X. and Wang, L. 2016. Mutations in PADI6 Cause Female Infertility Characterized by Early Embryonic Arrest. American Journal of Human Genetics, 99(3), 744-752. https://doi.org/ 10.1016/j.ajhg.2016.06.024.

120. Yang, P., Luan, X., Peng, Y., Chen, T., Su, S., Zhang, C., Wang, Z., Cheng, L., Zhang, X., Wang, Y., Chen, Z. J. and Zhao, H. 2017. Novel zona pellucida gene variants identified in patients with oocyte anomalies. Fertility and Sterility, 107(6), 1364-1369. https://doi.org/10.1016/j.fertnstert.2017.03.029. 
121. Yang, X., Shu, L., Cai, L., Sun, X., Cui, Y. and Liu, J. 2019. Homozygous missense mutation Arg207Cys in the WEE2 gene causes female infertility and fertilization failure. Journal of Assisted Reproduction and Genetics, 36(5), 965-971. https://doi.org/10.1007/s10815-019-01418-9.

122. Yariz, K. O., Walsh, T., Uzak, A., Spiliopoulos, M., Duman, D., Onalan, G., King, M. C. and Tekin, M. 2011. Inherited mutation of the luteinizing hormone/choriogonadotropin receptor (LHCGR) in empty follicle syndrome. Fertility and Sterility, 96(2). https://doi.org/10.1016/j.fertnstert.2011.05.057.

123. Ye, J., Coulouris, G., Zaretskaya, I., Cutcutache, I., Rozen, S. and Madden, T. L. 2012. Primer-BLAST: a tool to design target-specific primers for polymerase chain reaction. BMC Bioinformatics, 13(134), 1-11. https://doi.org/10.1186/1471-210513-134.

124. Young, N. K., Dae, H. J., Su, J. J., Moon, S. S., Mi, S. K. and Ki, T. K. 2007. Complete chorioamniotic membrane separation with fetal restrictive dermopathy in two consecutive pregnancies. Prenatal Diagnosis, 27(4), 352-355. https://doi.org/10.1002/pd.1673.

125. Yuan, P., He, Z., Zheng, L., Wang, W., Li, Y., Zhao, H., Zhang, V. W., Zhang, Q. and Yang, D. 2017. Genetic evidence of genuine' empty follicle syndrome: A novel effective mutation in the LHCGR gene and review of the literature. Human Reproduction, 32(4), 944-953. https://doi.org/10.1093/humrep/dex015.

126. Zhang, L., Cui, X., Schmitt, K., Hubert, R., Navidi, W. and Arnheim, N. 1992. Whole genome amplification from a single cell: Implications for genetic analysis. Proceedings of the National Academy of Sciences of the United States of America, 89(13), 5847-5851. https://doi.org/10.1073/pnas.89.13.5847.

127. Zhang, Y. X., He, W. Bin, Xiao, W. J., Meng, L. L., Tan, C., Du, J., Lu, G. X., Lin, G. and Tan, Y. Q. 2020. Novel loss-of-function mutation in MCM8 causes premature ovarian insufficiency. Molecular Genetics and Genomic Medicine, 8(4), e1165. https://doi.org/10.1002/mgg3.1165.

128. Zhao, S., Chen, T., Yu, M., Bian, Y., Cao, Y., Ning, Y., Su, S., Zhang, J. and Zhao, S. 2019. Novel WEE2 gene variants identified in patients with fertilization failure and female infertility. Fertility and Sterility, 111(3), 519-526. https://doi.org/ 10.1016/j.fertnstert.2018.11.018.

129. Zheng, Y. M., Wang, N., Li, L. and Jin, F. 2011. Whole genome amplification in preimplantation genetic diagnosis. Journal of Zhejiang University: Science B, 12(1), 1-11. https://doi.org/10.1631/jzus.B1000196.

130. Zhou, J., Mochizuki, T., Smeets, H., Antignac, C., Laurila, P., de Paepe, A., Tryggvason, K. and Reeders, S. T. 1993. Deletion of the paired $\alpha 5(\mathrm{IV})$ and $\alpha 6(1 \mathrm{~V})$ collagen genes in inherited smooth muscle tumors. Science, 261(5125), 1167-1169. https://doi.org/10.1126/science.8356449. 


\section{Pateicības}

Es vēlos izteikt sirsnīgu pateicību manām zinātniskajām vadītājām Annai Miskovai, Ingai Kempai un Lindai Gailītei. Esmu ḷoti pateicīga jums visām, ka uzticējāties man un uzṇēmāt mani kā savu studenti jau pirms vairāk nekā pieciem gadiem. Cienījamā Anna, liels paldies Jums, ka piedāvājāt man šo iespēju kḷūt par doktorantu, par Jūsu lieliskajām pētījumu idejām un piemēru, kā būt supersievietei. Cienījamā Inga, liels Jums paldies, ka vienmēr palīdzējāt sekot līdzi un nokārtot visas formālās un papīrsaistības ar universitāti un iemācījāt man vienmēr ievērot laika limitus. Paldies, ka, neskatoties uz attālumu,

Jūs vienmēr bijāt ḷoti tuvu. Cienījamā Linda, liels paldies par Jūsu laipno atsaucību, par visām Jūsu atbildēm uz maniem daudzajiem jautājumiem un lielisko uzmundrinājumu, ko Jūs vienmēr sniedzat, un galvenokārt - par iespēju kḷūt par daḷu no Jūsu laboratorijas.

Es vēlētos teikt lielu paldies savam recenzentam prof. Edvīnam Miklaševičam, liels paldies par Jūsu laiku, pavadītu, lasot un labojot manu darbu, un par vērtīgajiem komentāriem un padomiem. Pateicos promocijas darba apspriešanas komisijas organizētājiem un dalībniekiem par promocijas darba izvērtēšanu un sniegtajiem vērtīgajiem ieteikumiem. Esmu pateicīga, ka iegūstu savu doktora grādu tieši Rīgas Stradiņa universitātē, un lepojos, ka šo universitāti saucu par savu alma mater, es novēlu tai un visam tās akadēmiskajam personālam labklājību un izaugsmi.

Es vēlētos pateikties savai pirmajai vadītājai Natālijai Proṇinai, kura iepazīstināja mani ar cilvēka ǵenētikas pasauli. Es vienmēr būšu Jums pateicīga par manas intereses attīstīšanu ǵenētikas jomā, par lielisko atmosfēru un atbalstu, ko Jūs sniedzāt Bērnu universitātes slimnīcas DNS laboratorijā. Mana otrā izcilā skolotāja ǵenētikas pasaulē ir brīnišḳīgā Liene Korṇejeva. Liels paldies par to, 
ka vienmēr dalījāties ar zināšanām, par Jūsu nedziestošo azartu un daudzu konferenču laikā piedzīvoto jautrību.

Esmu pateicīga, ka man bija iespēja strādāt Dr. Violetas Fodinas uzraudzībā klīnikā "IVF Riga", liels paldies par mana profesionālā un arī ǵeogrāfiskā redzesloka paplašināšanu, kā arī par iespēju būt dalai no pirmsimplantācijas embriju ǵenētiskās testēšanas ieviešanas Latvijā.

Lielisks draugs, Biologijas fakultātes laboratorijas partneris un kolẹgis Dmitrijs Perminovs, liels paldies par visiem profesionāli un draudzīgi kopā pavadītajiem laikiem. Īpašs paldies par laikiem, kad mēs plānojām un izstrādājām embriju analīzes eksperimentus, kas rezultējās mūsu pirmajā publikācijā. Pateicos par uzaicinājumu kḷūt par E. Gulbja laboratorijas komandas daḷu. Es novēlu Tev lielisku profesionālo karjeru un visu to labāko ar Tavu doktora disertāciju.

Tāpat es vēlētos pateikties par lielisku iepazīšanos ar Gitu Tauriṇu. Vēl 2013. gadā viṇa nostiprināja manu pārliecību, ka genētiķi vienmēr ir visinteresantākās personības. Liels paldies, ka iesaistīji mani darbā ar studentiem RSU, kur es laimīgi pavadīju gandrīz četrus gadus kā nepilna laika molekulārās ǵenētikas praktisko nodarbību pasniedzēja. Es gribētu teikt lielu paldies Dmitrijam Rotam, kurš man palīdzēja darbā ar dzemdes kakla nepietiekamību. Liels paldies par Tavu ieguldījumu un lieliskajiem padomiem. Novēlu brīnišķ̄ịu nobeigumu Tavām doktora studijām Nīderlandē un veiksmīgu atgriešanos Latvijā, lai arī turpmāk attīstìtu genētikas sfēru šeit.

Liels paldies visiem maniem draugiem, kuri atbalstīja un uzmundrināja mani šajā ceḷā uz doktora grādu. Īpašs paldies manam vīram Vladislavam Ivanovam, paldies par Tavu nebeidzamo atbalstu un ticību man. Un vislielākais paldies manai dārgajai mammai par mīlestību un atbalstu, kas vienmēr man palīdzēja manas dzīves gaitās 
Pielikumi 
1. pielikums

\section{Centrālās medicīnas êtikas komitejas apstiprinājums veikt pētījumu "Neauglības genētiskās etioloğijas iemeslu izpēte"}

\section{Centrālā medicīnas ētikas komiteja}

Brivibas iela 72, Rīga. LV-1011 • Tälr. 67876182 • Fakss 67876071 • E-pasts: vm $Q$ vm.gov.lv 14.04.2016. Nr.1/16-04-14

Rīgā

14.04.2016. Nr.1/16-04-14

Rīgas Stradina Universitātes

Molekulārās G̣enētikas

Zinātniskajai laboratorijai

Atzinums par pētījuma pieteikumu

"Neauglības genenēiskās etologijas

iemeslu izpēte"

Centrālā medicīnas ètikas komiteja 2015.gada 22.septembrī izskatîja Rīgas Stradina Universitātes Molekulārās Genētikas Zinātniskās laboratorijas iesniegto pētījuma pieteikumu "Neauglības genētiskäs etologijas iemeslu izpēte".

Pamatojoties uz Centrālās medicinas ētikas komitejas 2015.gada 22.septembra sèdes protokola Nr.6 punktu Nr.3 - pieteikuma projektu konceptuāli atbalstīt, bet, lai sanemtu apstiprinājumu, veikt precizējumus un labojumus projekta pieteikuma dokumentācijā - un iesniegtajiem pieteikuma projekta precizējumiem un labojumiem, tiek izsniegts atzinums, ka Rīgas Stradiṇa Universitātes Molekulāāās Gienētikas Zinātniskās laboratorijas pētījuma pieteikums "Neauglïbas ġenētiskäs etoloǵijas iemeslu izpēte" nav pretrunā ar bioētikas normām.

Centrālās medicīnas êtikas komitejas priekšsēdētāja 
2. pielikums

Centrālās medicīnas ētikas komitejas apstiprinājums veikt pētījumu "Istmocervikālās nepietiekamības ǵenētiskās etioloǵijas iemeslu izpēte"

\author{
Centrālā medicīnas ētikas komiteja \\ Btivibas iela 72. Riga. LV-1011 • Talr. 67876182 • Fakss 67876071 • E-pasts: vm(a)vm.gov.lv \\ 21.03.2018. Nr.2/18-03-21 \\ Rīgā
}

Rīgas Stradina universitātes Molekulārās G̣enētikas Zinātniskajai laboratorijai

Atzinums par pētijumu

„,Istmocervikālās nepietiekamības

genētiskās etiologijas iemeslu izpēte"

Centrālā medicīnas ētikas komiteja 2018.gada 18.janvārī ir izskatījusi Rīgas Stradiṇa Universitātes Molekulārās G̦enētikas Zinātniskās laboratorijas iesniegto pētījumu ,Istmocervikālās nepietiekamības genētiskās etiologijas iemeslu izpēte".

Pamatojoties uz Centrālās medicīnas ētikas komitejas 2018.gada 18.janvāra sēdes protokola Nr.2018-1 punktu Nr.5 un iesniegtajiem labojumiem, tiek izsniegts atzinums, ka Rīgas Stradina Universitātes Molekulārās Gụenētikas Zinātniskās laboratorijas pētijums „Istmocervikālās nepietiekamības genētiskās etiologiijas iemeslu izpēte" nav pretrunā ar bioētikas normām.

Centrālās medicīnas ētikas

komitejas priekšsēēetājs

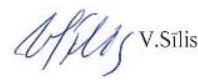


3. pielikums

Visu līdzautoru piekrišana publikācijas "Performance comparison of two whole genome amplification techniques in frame of multifactor preimplantation genetic testing" izmantošanai Ludmilas Voložonokas promoocijas darbā (autoru secībā kā publikācijā)

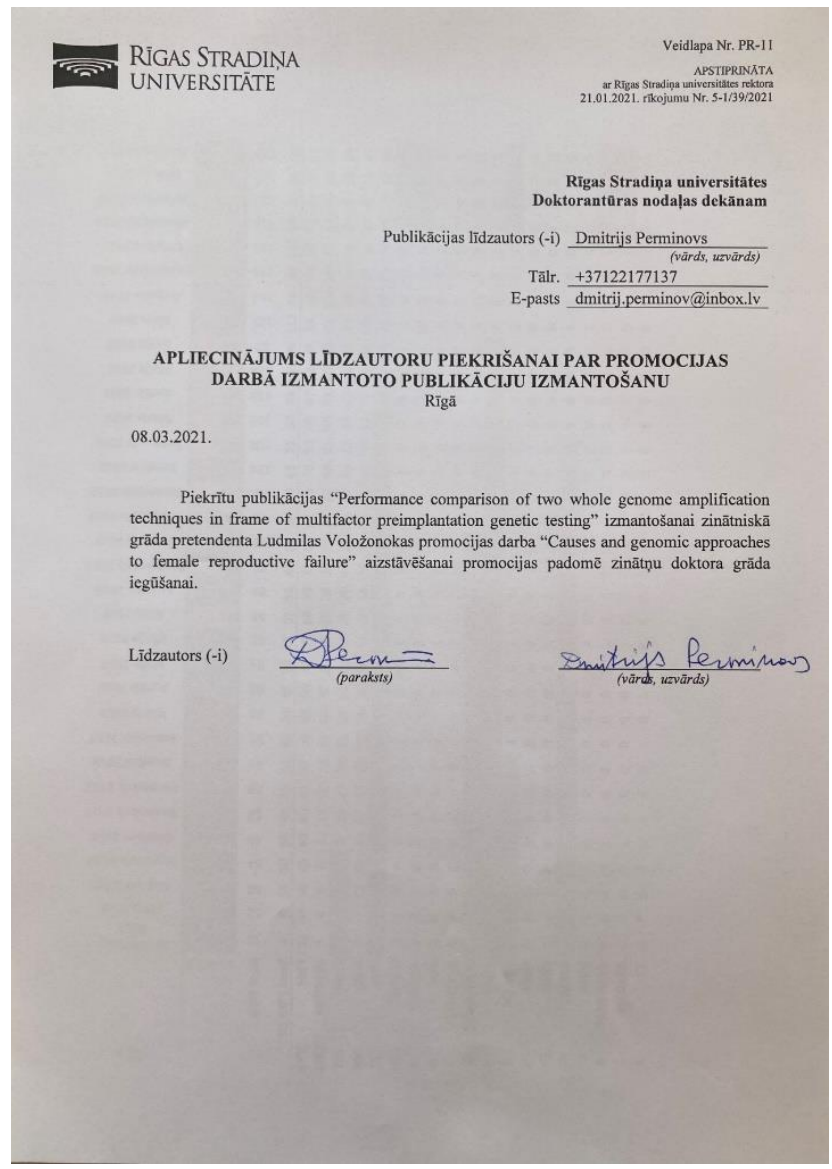


3. pielikuma turpinājums

Rigas Stradina universitātes Doktorantúras noda|as dekănam

Publikãcijas līdzautors (-i) Liene Kornejeva

Tâlr. + +37126548489

E-pasts Liene.Kornejeva@ivfriga.lv

\section{APLIECINĀJUMS LĪDZAUTORU PIEKRIŠANAI PAR PROMOCIJAS DARBĀ IZMANTOTO PUBLIKĀCIJU IZMANTOŠANU Rīgā}

07.06.2021

Piekrītu publikācijas "Performane comparison of two whole genome amplification techniques in frame of multifactor preimplantation genetic testing" izmantošanai zinātniskā grāda pretendenta Ludmila Voložonoka promocijas darba "Sievietes reproduktĩvās mazspējas iemesli un genomiskās pieejas to risināšanai" (angl. "Causes and genomic approaches to female reproductive failure") aizstāvēšanai promocijas padomẽ zinātṇu doktora grāda iegūšanai.

Līdzautors (-i)

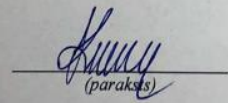

(vârds, uzvârds) 


\section{3. pielikuma turpinājums}

Rigas STRADINA

UNIVERSITATE

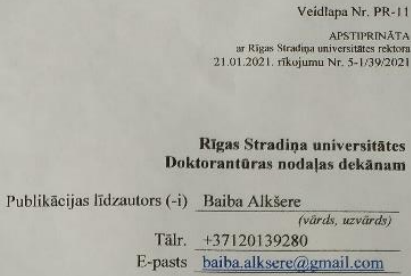

Rigas Stradina universitātes Doktoranteras nodalas dekănam

Publikācijas lĩdzautors (-i) Baiba Alkšer

(värds, uzvärds)

Tãlr. +37120139280

E-pasts baiba.alksere(a)gmail.com

\section{APLIECINĀJUMS LĨDZAUTORU PIEKRIŠANAI PAR PROMOCIJAS}

DARBĀ IZMANTOTO PUBLIKĀCIJU IZMANTOŠANU

Rigā

07.06 .2021

Piekrītu publikācijas "Performane comparison of two whole genome amplification techniques in frame of multifactor preimplantation genetic testing" izmantošanai zinātniskā grāda pretendenta Ludmila Voložonoka promocijas darba "Sievietes reproduktīvās mazspejjas iemesli un genomiskās pieejas to risināšanai" (angl. "Causes and genomic approaches to female reproductive failure") aizstãvēšanai promocijas padomē zinātṇu doktora grâda iegūšanai

Lìdzautors $(-\mathrm{i})$

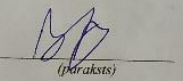




\section{3. pielikuma turpinājums}

Rígas STRAdina

Veidlapa Nr. PR-11

APSTIPRINATA

ar Rigas Stradina universitătes rektor

UNIVERSITĀTE 21.01.2021, rikojumu Nr. 5-1/39/2021

Rĩgas Stradina universitātes Doktorantūras noda|as dekānam

Publikãcijas lĩdzautors Natâlija Novikova

(-i)

Tālr. +37127731090

(vârds, uzvārds)

E-pasts natalija.novikova19@gmail.com

\section{APLIECINĀJUMS LĪDZAUTORU PIEKRIŠANAI PAR PROMOCIJAS DARBĀ IZMANTOTO PUBLIKĀCIJU IZMANTOŠANU \\ Rīgā}

10.06 .2021

Piekrītu publikācijas "Performance comparison of two whole genome amplification techniques in frame of multifactor preimplantation genetic testing” izmantošanai zinātniskā grāda pretendenta Ludmila Voložonoka promocijas darba "Sievietes reproduktīvās mazspējas iemesli un genomiskās pieejas to risināšanai" (angl. "Causes and genomic approaches to female reproductive failure") aizstāvēšanai promocijas padomē zinātṇu doktora grāda iegūšanai.

Lìdzautors (-i)

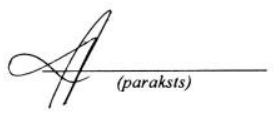

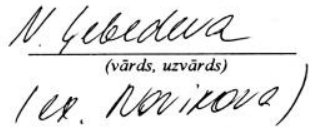


3. pielikuma turpinājums

RİGAs STRADINa

UNIVERSITĀTE

\author{
Veidlapa Nr. PR-1 \\ APSTIPRINATTA \\ ar RIgas Stradina universitates rektio \\ ar RTgas Stradina universitates rekiora
21.01.2021. rikojumu $\mathrm{Nr}$. 5-1/39/2021 \\ Rigas Stradiṇa universitātes \\ Doktorantūras nodą̣as dekānam \\ Publikācijas līdzautors (-i) Evija Pīmane \\ Tālr. +37129833445 \\ E-pasts epimane@inbox.lv
}

\title{
APLIECINĀJUMS LĪDZAUTORU PIEKRIŠANAI PAR PROMOCIJAS DARBĀ IZMANTOTO PUBLIKĀCIJU IZMANTOŠANU

\author{
Rīgā
}

10.06 .2021

Piekrītu publikācijas "Performance comparison of two whole genome amplification techniques in frame of multifactor preimplantation genetic testing" izmantošanai zinātniskā grāda pretendenta Ludmila Voložonoka promocijas darba "Sievietes reproduktīvās mazspējas iemesli un genomiskās pieejas to risināšanai" (angl. "Causes and genomic approaches to female reproductive failure") aizstāvēšanai promocijas padomē zinātṇu doktora grāda iegūšanai.

Līdzautors (-i)

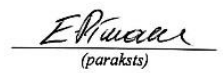

$\frac{\text { Evija Pimane }}{\text { (värds, uzvärds) }}$ 


\section{3. pielikuma turpinājums}

RIGAS STRADINA UNIVERSITĀTE
Veidlapa Nr. PR-11

APSTIPRINĀTA

ar Rigas Stradina univerit 21.01.2021. rikojumu Nr. 5-1/39/2021

Rīgas Stradina universitătes Doktorantûras nodalas dekānam

Publikācijas līdzautors (-i) Arita Blumberga

(värds, uzvärds)

Tālr. +37126088104

E-pasts aritablumberga@gmail.com

\section{APLIECINĀJUMS LĪDZAUTORU PIEKRIŠANAI PAR PROMOCIJAS DARBĀ IZMANTOTO PUBLIKĀCIJU IZMANTOŠANU \\ Rìgā}

10.06 .2021

Piekrītu publikācijas "Performance comparison of two whole genome amplification techniques in frame of multifactor preimplantation genetic testing" izmantošanai zinātniskā grāda pretendenta Ludmila Voložonoka promocijas darba "Sievietes reproduktîvās mazspējas iemesli un genomiskās pieejas to risināsanai" (angl. "Causes and genomic approaches to female reproductive failure") aizstāvē̌anai promocijas padomē zinātṇu doktora grāda iegūšanai.

Lĩdzautors (-i)

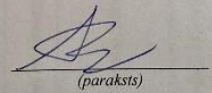

$$
\frac{\text { ARITA BLUMBERGA }}{\text { (värds, uzuărds) }}
$$




\section{3. pielikuma turpinājums}

Publikãcijas līdzautors (-i) Inga Kempa

Tālr. +37126679671

(vārds, uzvārds)

E-pasts Inga.Kempa@rsu.lv

\section{APLIECINĀJUMS LĪDZAUTORU PIEKRIŠANAI PAR PROMOCIJAS DARBĀ IZMANTOTO PUBLIKĀCIJU IZMANTOŠANU \\ Rīgā}

10.06.2021.

Piekrītu publikācijas "Performance comparison of two whole genome amplification techniques in frame of multifactor preimplantation genetic testing" izmantošanai zinātniskā grāda pretendenta Ludmilas Voložonokas promocijas darba "Sievietes reproduktīvās mazspejjas iemesli un genomiskās pieejas to risināšanai" (angl. "Causes and genomic approaches to female reproductive failure") aizstāvēšanai promocijas padomē zinātnu doktora grāda iegūšanai.

Lĩdzautors (-i)
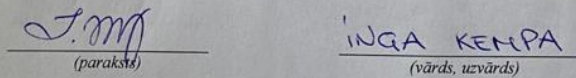


\title{
3. pielikuma turpinājums
}

RIGAS STRADINA

UNIVERSITĀTE
Veidlapa Nr. PR-11

APSTIPRINĀTA

ar Riggas Stradina universitātes rektora 21.01.2021. rīkojumu Nr. 5-1/39/2021

Rīgas Stradiṇa universitātes

Doktorantūras nodalas dekānam

\author{
Publikācijas līdzautors (-i) Anna Miskova \\ Tālr. +37120271072 \\ (vārds, uzvārds) \\ dr.anna.miskova@gmail.co \\ E-pasts $m$
}

\section{APLIECINĀJUMS LĪDZAUTORU PIEKRIŠANAI PAR PROMOCIJAS DARBĀ IZMANTOTO PUBLIKĀCIJU IZMANTOŠANU}

Rīgā

10.06.2021

Piekrītu publikācijas "Performance comparison of two whole genome amplification techniques in frame of multifactor preimplantation genetic testing" izmantošanai zinātniskā grāda pretendenta Ludmila Voložonoka promocijas darba "Sievietes reproduktīvās mazspējas iemesli un genomiskās pieejas to risināšanai" (angl. "Causes and genomic approaches to female reproductive failure") aizstāvēšanai promocijas padomē zinātnu doktora grāda iegūšanai.

Līdzautors (-i)
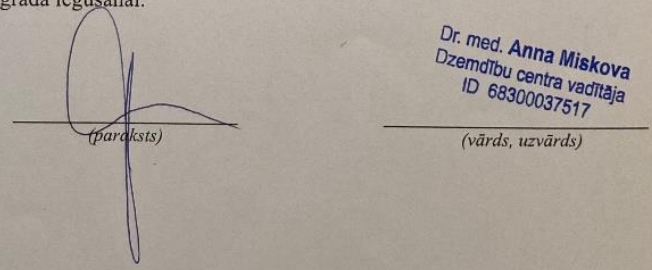


\section{3. pielikuma turpinājums}

Rīgas Stradina universitātes Doktorantūras nodaḷas dekānam

Publikācijas līdzautors (-i) Linda Gailīte

Tālr. +37129435971

(värds, uzvärds)

E-pasts Linda.Gailite@rsu.Iv

\section{APLIECINĀJUMS LĪDZAUTORU PIEKRIŠANAI PAR PROMOCIJAS DARBĀ IZMANTOTO PUBLIKĀCIJU IZMANTOŠANU \\ Rīgā}

07.06 .2021

Piekrītu publikācijas "Performane comparison of two whole genome amplification techniques in frame of multifactor preimplantation genetic testing" izmantošanai zinātniskā grāda pretendenta Ludmila Voložonoka promocijas darba "Sievietes reproduktīvās mazspējas iemesli un genomiskās pieejas to risināšanai" (angl. "Causes and genomic approaches to female reproductive failure") aizstāvēšanai promocijas padomẽ zinātṇu doktora grāda iegūšanai.

Lìdzautors (-i)

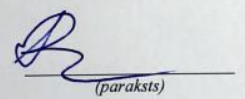

Linda Gailīte

(vārds, uzvārds) 


\section{3. pielikuma turpinājums}

RīGAS STRADINa

Veidlapa Nr. PR-11

APSTIPRINĀTA

UNIVERSITĀTE

Rīgas Stradiṇa universitātes Doktorantūras nodaḷas dekānam

Publikācijas līdzautors (-i) Violeta Fodina

(vārds, uzvārds)

Tālr. +37126441369

E-pasts Violeta.Fodina@ivfriga.eu

\section{APLIECINĀJUMS LĪDZAUTORU PIEKRIŠANAI PAR PROMOCIJAS DARBĀ IZMANTOTO PUBLIKĀCIJU IZMANTOŠANU \\ Rīgā}

10.06.2021

Piekrītu publikācijas "Performance comparison of two whole genome amplification techniques in frame of multifactor preimplantation genetic testing” izmantošanai zinātniskā grāda pretendenta Ludmila Voložonoka promocijas darba "Sievietes reproduktīvãs mazspējas iemesli un genomiskās pieejas to risināsanai" (angl. "Causes and genomic approaches to female reproductive failure") aizstāvēšanai promocijas padomē zinātṇu doktora grāda iegūšanai.

Lìdzautors (-i)
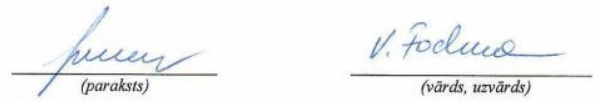
4. pielikums

Visu līdzautoru piekrišana publikācijas "Reducing misdiagnosis caused by maternal cell contamination in genetic testing for early pregnancy loss" izmantošanai Ludmilas Voložonokas promoocijas darbā (autoru secībā kā publikācijā)

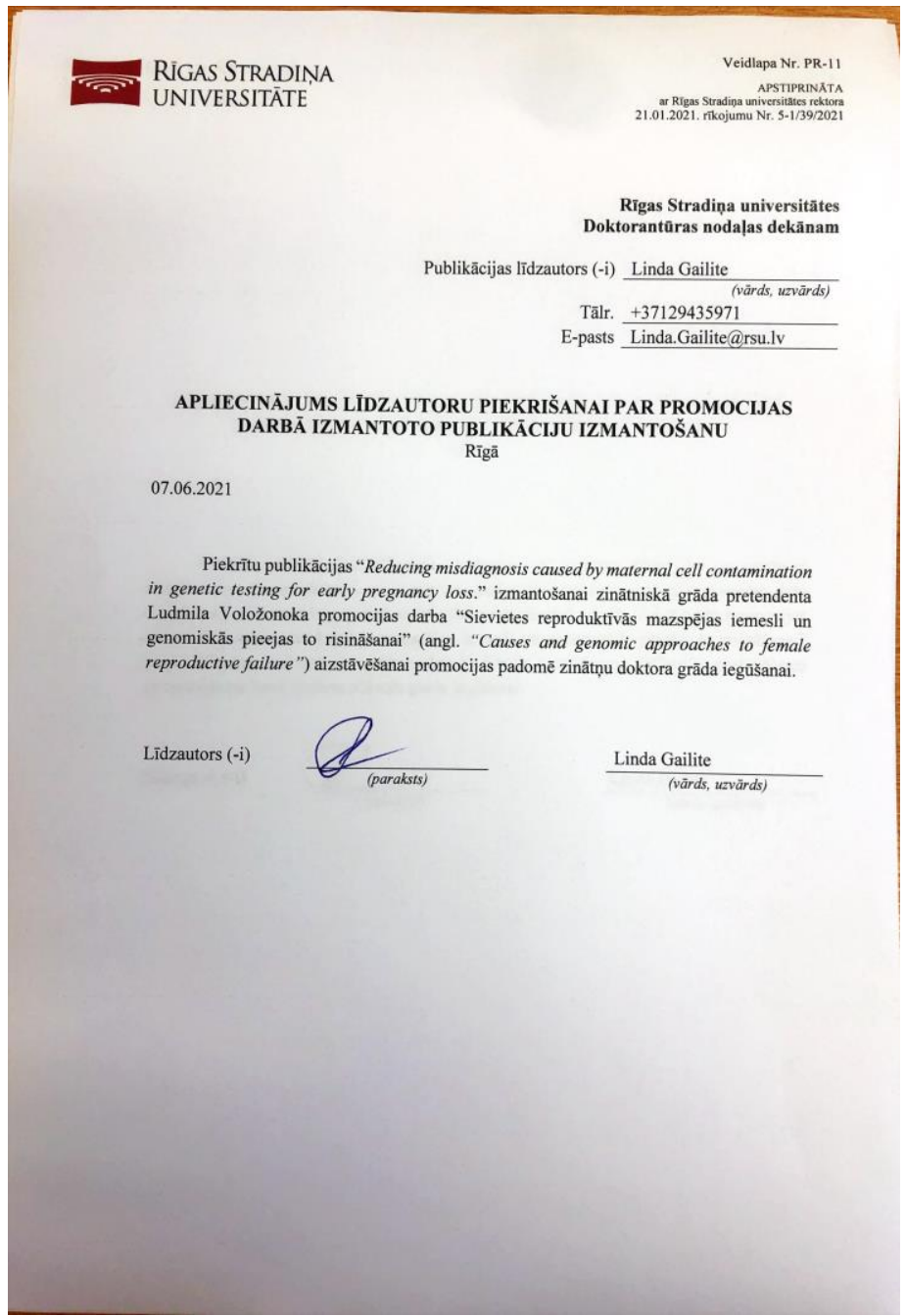




\section{4. pielikuma turpinājums}

RígAS STRADINA

UNIVERSITĀTE
Veidlapa Nr. PR-11

APSTIPRINÁTA

ar Rigas Stradina universit ties telor ar Rigas Stradina universitătes rektora
21.01.2021. rikojumu Nr. 5-1/39/202

Rīgas Stradina universitātes Doktorantüras nodaḷas dekãnam

\section{Publikãcijas līdzautors (-i) Dmitrijs Perminovs}

(värds, uzvärds)

Tālr. +37122177137

E-pasts Dmitrij.Perminov@inbox.lv

\section{APLIECINĀJUMS LĪDZAUTORU PIEKRIŠANAI PAR PROMOCIJAS DARBĀ IZMANTOTO PUBLIKĀCIJU IZMANTOŠANU \\ Rīgā}

15.06.2021

Piekritu publikācijas "Reducing misdiagnosis caused by maternal cell contamination in genetic testing for early pregnancy loss" izmantošanai zinātniskā grāda pretendenta Ludmila Voložonoka promocijas darba "Sievietes reproduktīvās mazspējas iemesli un genomiskās pieejas to risināšanai" (angl. "Causes and genomic approaches to female reproductive failure") aizstāvēšanai promocijas padomē zinātņu doktora grāda iegūšanai.

Lìdzautors (-i)
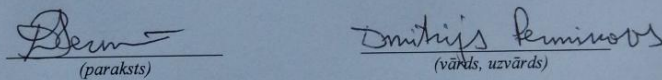
4. pielikuma turpinājums

RIGas STRADINa

UNIVERSITĀTE

Veidlapa Nr. PR-11

APSTIPRINĀTA

ar Rigas Stradipa universitates rektora 21.01.2021. rikojumu Nr. 5-1/39/2021

Rīgas Stradina universitātes Doktorantūras nodaḷas dekānam

Publikācijas līdzautors (-i) Liene Korṇejeva

Tālr. +37126548489

(vărds, uzvārds)

E-pasts Liene.Kornejeva@ivfriga.lv

\section{APLIECINĀJUMS LĪDZAUTORU PIEKRIŠANAI PAR PROMOCIJAS DARBĀ IZMANTOTO PUBLIKĀCIJU IZMANTOŠANU \\ Rīgā}

07.06 .2021

Piekrītu publikācijas "Reducing misdiagnosis caused by maternal cell contamination in genetic testing for early pregnancy loss" izmantošanai zinātniskā grāda pretendenta Ludmila Voložonoka promocijas darba "Sievietes reproduktīvās mazspējas iemesli un genomiskās pieejas to risināšanai" (angl. "Causes and genomic approaches to female reproductive failure") aizstāvē̌̌anai promocijas padomē zinātṇu doktora grāda iegūšanai.

Lìdzautors (-i)

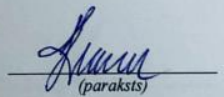

LENE KORNETEBA (vãrds, uzvārds) 


\section{4. pielikuma turpinājums}

Rĩgas Stradiña

Veidlapa Nr. PR-11

APSTIPRINÃTA

r Riggas Stradipa universitžtes rektor 21.01.2021. rikojumu Nr. 5-1/39/2021

Rīgas Stradiṇa universitātes Doktorantūras nodaḷas dekānam

Publikācijas līdzautors (-i) Violeta Fodina

Tālr. +37126441369

(vârrds, uzvārds)

E-pasts Violeta.Fodina@ivfriga.eu

\section{APLIECINĀJUMS LĪDZAUTORU PIEKRIŠANAI PAR PROMOCIJAS DARBĀ IZMANTOTO PUBLIKĀCIJU IZMANTOŠANU \\ Rīgā}

10.06 .2021

Piekrītu publikācijas "Reducing misdiagnosis caused by maternal cell contamination in genetic testing for early pregnancy loss" izmantošanai zinātniskā grāda pretendenta Ludmila Voložonoka promocijas darba "Sievietes reproduktīvās mazspējas iemesli un genomiskās pieejas to risināsanai" (angl. "Causes and genomic approaches to female reproductive failure") aizstāvēšanai promocijas padomē zinātṇu doktora grāda iegūšanai.

Lìdzautors (-i)
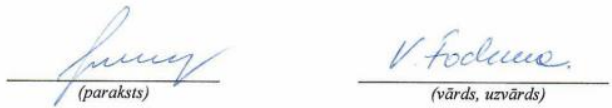


\section{4. pielikuma turpinājums}

RíGAS STRADIN̦A

UNIVERSITĀTE

\section{APLIECINĀJUMS LĪDZAUTORU PIEKRIŠANAI PAR PROMOCIJAS DARBĀ IZMANTOTO PUBLIKĀCIJU IZMANTOŠANU}

Rīgā

10.06 .2021

Piekrītu publikācijas "Reducing misdiagnosis caused by maternal cell contamination in genetic testing for early pregnancy loss" izmantošanai zinātniskā grāda pretendenta Ludmilas Voložonokas promocijas darba "Sievietes reproduktīvās mazspējas iemesli un genomiskās pieejas to risināšanai" (angl. "Causes and genomic approaches to female reproductive failure") aizstāvēšanai promocijas padomē zinātnu doktora grāda iegūšanai.

Līdzautors (-i)

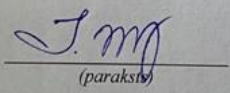

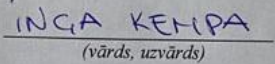




\section{4. pielikuma turpinājums}

RIGAS STRADINA

UNIVERSITĀTE

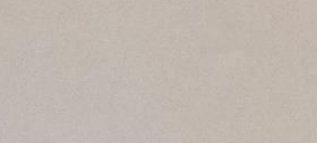
Publikācijas līdzautors (-i) Anna Miskova
Tālr. +37120271072 dr.anna.miskova@gmail.co
E-pasts $\mathrm{m}$

\section{APLIECINĀJUMS LĪDZAUTORU PIEKRIŠANAI PAR PROMOCIJAS DARBĀ IZMANTOTO PUBLIKĀCIJU IZMANTOŠANU}

Rīgā

10.06 .2021

Piekrītu publikācijas "Reducing misdiagnosis caused by maternal cell contamination in genetic testing for early pregnancy loss" izmantošanai zinātniskā grāda pretendenta Ludmila Voložonoka promocijas darba "Sievietes reproduktīvās mazspējas iemesli un genomiskās pieejas to risināšanai" (angl. "Causes and genomic approaches to female reproductive failure") aizstāvēšanai promocijas padomē zinātṇu doktora grāda iegūšanai.

Lìdzautors (-i)
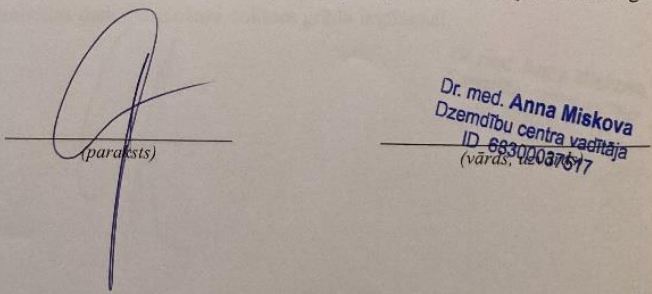

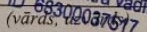


5. pielikums

Visu līdzautoru piekrišana publikācijas "Genetic landscape of preterm birth due to cervical insufficiency: Comprehensive gene analysis and patient next-generation sequencing data interpretation" izmantošanai Ludmilas Voložonokas promoocijas darbā (autoru secībā kā publikācijā)

RIGAS STRADIN,A

UNIVERSITĀTE

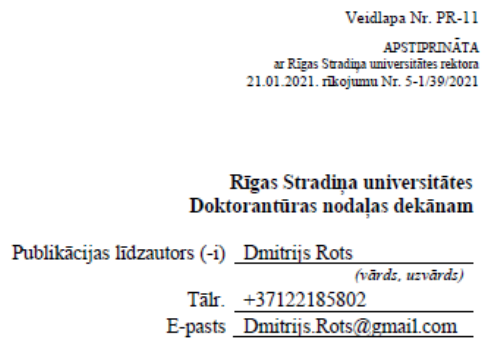

E-pasts Dmitrijs.Rots@gmail.com

\section{APLIECINĀJUMS LĪDZAUTORU PIEKRIŠANAI PAR PROMOCIJAS DARBĀ IZMANTOTO PUBLIKĀCIJU IZMANTOŠANU \\ Rìgā}

Piekritu publikācijas "Genetic landscape of preterm birth due to cervical insufficiency: Comprehensive gene analysis and patient next-generation sequencing data interpretation." izmantošanai zinātniskā grāda pretendenta Ludmila Voložonoka promocijas darba "Sievietes reproduktîvās mazspējas iemesli un genomiskās pieejas to risināšanai" (ang1. "Causes and genomic approaches to female reproductive failure") aizstāvēšanai promocijas padomē zinātñu doktora grāđa iegūišanai.

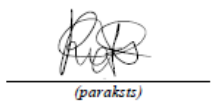

Dmitrijs Rots (värds, uzvärds) 


\section{5. pielikuma turpinājums}

RīGAS STRADINa

UNIVERSITĀTE
Veidlapa Nr. PR-1

APSTIPRINĀTA

ar Rigas Stradipa universitates rektor 21.01.2021. rikojumu Nr. 5-1/39/202

Rigas Stradiṇa universitātes Doktorantūras noda|ąas dekānam

Publikācijas līdzautors (-i) Inga Kempa

Tālr. +37126679671

(vārds, uzvārds)

E-pasts Inga.Kempa@rsu.lv

\section{APLIECINĀJUMS LĨDZAUTORU PIEKRIŠANAI PAR PROMOCIJAS DARBĀ IZMANTOTO PUBLIKĀCIJU IZMANTOŠANU}

Rīgā

10.06.2021

Piekrītu publikācijas "Genetic landscape of preterm birth due to cervical insufficiency: Comprehensive gene analysis and patient next-generation sequencing data interpretation" izmantošanai zinātniskā grāda pretendenta Ludmilas Voložonokas promocijas darba "Sievietes reproduktīvās mazspējas iemesli un genomiskās pieejas to risināšanai" (angl. "Causes and genomic approaches to female reproductive failure") aizstāvēšanai promocijas padomē zinātṇu doktora grāda iegūšanai.

Līdzautors (-i)

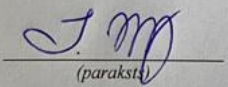

INGA KEMPA 


\section{5. pielikuma turpinājums}

RīGAS STRADINa

UNIVERSITĀTE
Veidlapa Nr. PR-11

APSTIPRINȦTA Rigas Stradipa universitätes rektor ar Rigas Stradipa universitătes rektora
21.01.2021. rikkojumu Nr. 5-1/39/2021

Rīgas Stradina universitātes Doktorantūras nodaḷas dekānam

Publikācijas līdzautors (-i) Anna Kornete

(vãrds, uzvārds)

Tālr. +37128312094

E-pasts Anna.Kornete@rsu.lv

\section{APLIECINĀJUMS LĪDZAUTORU PIEKRIŠANAI PAR PROMOCIJAS DARBĀ IZMANTOTO PUBLIKĀCIJU IZMANTOŠANU \\ Rīgā}

07.06 .2021

Piekrītu publikācijas "Genetic landscape of preterm birth due to cervical insufficiency: Comprehensive gene analysis and patient next-generation sequencing data interpretation." izmantošanai zinātniskā grāda pretendenta Ludmila Voložonoka promocijas darba "Sievietes reproduktīvās mazspējas iemesli un genomiskās pieejas to risināšanai" (angl. "Causes and genomic approaches to female reproductive failure") aizstāvēšanai promocijas padomē zinātṇu doktora grāda iegūšanai.

Līdzautors (-i)

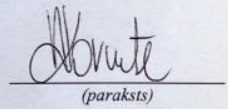

\section{Anna Kornete}

(vārds, uzvārds) 
5. pielikuma turpinājums

Tâlr. +37129415195

E-pasts Dace.Rezeberga@rsu.lv

\section{APLIECINĀJUMS LĪDZAUTORU PIEKRIŠANAI PAR PROMOCIJAS DARBĀ IZMANTOTO PUBLIKĀCIJU IZMANTOŠANU}

Rīgā

10.06 .2021

Piekrītu publikācijas "Genetic landscape of preterm birth due to cervical insufficiency: Comprehensive gene analysis and patient next-generation sequencing data interpretation" izmantošanai zinātniskā grāda pretendenta Ludmila Voložonoka promocijas darba "Sievietes reproduktīvās mazspējas iemesli un genomiskās pieejas to risināšanai" (angl. "Causes and genomic approaches to female reproductive failure") aizstāvēšanai promocijas padomē zinātņu doktora grāda iegūšanai.

Līdzautors (-i)

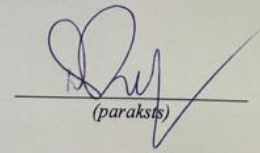

profesore

Dace Rezeberga

(vārds, uzvārds) 


\section{5. pielikuma turpinājums}

Rīgas Stradina universitātes Doktorantūras noda|as dekānam

Publikācijas līdzautors (-i) Linda Gailite (värds, uzvärds)

Tālr. +37129435971

E-pasts Linda.Gailite@rsu.lv

\section{APLIECINĀJUMS LĪDZAUTORU PIEKRIŠANAI PAR PROMOCIJAS DARBĀ IZMANTOTO PUBLIKĀCIJU IZMANTOŠANU \\ Rìgā}

07.06 .2021

Piekrītu publikācijas "Genetic landscape of preterm birth due to cervical insufficiency: Comprehensive gene analysis and patient next-generation sequencing data interpretation." izmantošanai zinātniskā grāda pretendenta Ludmila Voložonoka promocijas darba "Sievietes reproduktīvās mazspējas iemesli un genomiskās pieejas to risināsanai" (angl. "Causes and genomic approaches to female reproductive failure") aizstāvēšanai promocijas padomē zinātṇu doktora grâda iegūsanai.

Lìdzautors (-i)

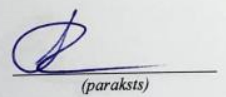

Linda Gailite

(vārds, uzvărds) 


\section{5. pielikuma turpinājums}

RIGAS STRADINA UNIVERSITĀTE
Veidlapa Nr. PR-11

APSTIPRINĀTA

ar Riggas Stradina universiț̈tes rektora 21.01.2021, rikojumu Nr. 5-1/39/2021

Rīgas Stradiṇa universitātes Doktorantūras nodalas dekānam

Publikācijas līdzautors (-i) Anna Miskova

Tālr.

$$
\text { (vārds, uzvārds) }
$$

dr.anna.miskova@gmail.co

E-pasts $m$

\section{APLIECINĀJUMS LİDZAUTORU PIEKRIŠANAI PAR PROMOCIJAS DARBĀ IZMANTOTO PUBLIKĀCIJU IZMANTOŠANU \\ Rīgā}

10.06 .2021

Piekrītu publikācijas "Genetic landscape of preterm birth due to cervical insufficiency: Comprehensive gene analysis and patient next-generation sequencing data interpretation" izmantošanai zinātniskā grāda pretendenta Ludmila Voložonoka promocijas darba "Sievietes reproduktīvās mazspējas iemesli un genomiskās pieejas to risināšanai" (angl. "Causes and genomic approaches to female reproductive failure") aizstāvēšanai promocijas padomē zinātṇu doktora grāda iegūšanai.

Lĩdzautors (-i)

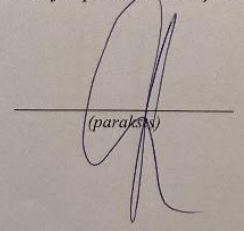

